UNIVERSIDADE DE SÃO PAULO

ESCOLA DE ENFERMAGEM DE RIBEIRÃO PRETO

JAQUELINE RODRIGUES STEFANINI

Pesquisa-ação e práticas restaurativas para a prevenção da violência escolar: percepções dos professores 
Pesquisa-ação e práticas restaurativas para a prevenção da violência escolar: percepções dos professores

\section{Versão Original}

Tese apresentada ao Programa de PósGraduação em Enfermagem Psiquiátrica da Escola de Enfermagem de Ribeirão Preto da Universidade de São Paulo para obtenção do título de Doutora em Ciências.

Linha de pesquisa: Promoção de Saúde Mental

Orientadora: Profa. Dra. Zeyne Alves Pires Scherer

Coorientadora: Profa. Dra. Ana Isabel Sani 
Autorizo a reprodução e divulgação total ou parcial deste trabalho, por qualquer meio convencional ou eletrônico, para fins de estudo e pesquisa, desde que citada a fonte.

Stefanini, Jaqueline Rodrigues

Pesquisa-ação e práticas restaurativas para a prevenção da violência escolar: percepções dos professores. Ribeirão Preto, 2019.

96 p.: il. ; $30 \mathrm{~cm}$

Tese de Doutorado, apresentada à Escola de Enfermagem de Ribeirão Preto/USP. Área de concentração: Enfermagem Psiquiátrica.

Orientadora: Profa. Dra. Zeyne Alves Pires Scherer

Coorientadora: Profa. Dra. Ana Isabel Sani

1. Violência Escolar. 2. Prevenção da Violência. 3.Práticas Restaurativas. 4.Pesquisaação. 
Nome: STEFANINI, Jaqueline Rodrigues

Título: Pesquisa-ação e práticas restaurativas para a prevenção da violência escolar: percepções dos professores

Tese apresentada ao Programa de PósGraduação em Enfermagem Psiquiátrica da Escola de Enfermagem de Ribeirão Preto da Universidade de São Paulo para obtenção do título de Doutora em Ciências.

Aprovada em:

Banca Examinadora

Prof. Dr.

Instituição:

Prof. Dr.

Instituição:

Prof. Dr.

Instituição:

Prof. Dr.

Instituição:

Prof. Dr.

Instituição: 
A presente tese foi realizada com apoio financeiro do Conselho Nacional de Desenvolvimento Cientifico e Tecnológico (CNPq) Processo: 159545/2015-3. 
A todos os professores das escolas da rede pública de educação básica do Brasil, que enfrentam desafios importantes no processo de construção do conhecimento. 


\section{AGRADECIMENTOS}

A Deus, pela oportunidade de viver e aprender diariamente com a simplicidade da vida. Por ter me concedido inteligência e condições para a realização deste trabalho.

À Profa. Dra. Zeyne o meu sincero agradecimento! Por toda aprendizagem desde o mestrado. Pelo trabalho em parceria, ensinamentos e correções.

À Profa. Dra. Ana Sani, por toda aprendizagem. Pelos ensinamentos, atenção e respeito que sempre teve comigo. Muito obrigada.

Aos meus pais, Ana Maria e Nivaldo, por terem me aceitado, apoiado em todas as decisões e zelado por mim. Agradeço profundamente minha família, minha irmã Janaina e meu cunhado Francisco, por tudo: o incentivo aos estudos, os ensinamentos na vida, o colo e o amor.

Ao Fábio, meu companheiro, pela paciência, tolerância, resistência e apoio em todos os momentos da vida. À sua família pelo carinho e atenção.

Aos parceiros de trabalho durante a pesquisa: Luciana, Nathalia e Edson. Contribuíram muito com o desenvolvimento desse trabalho. Em especial à Débora e à Marciana, pelas horas trabalhadas juntas e, que além de serem parceiras no trabalho são também amigas especiais!

Aos parceiros do Grupo de Estudos Interdisciplinar sobre Violência (GREIVI) e do Observatório de Violência e Crime (OPVC), agradeço as oportunidades e todo aprendizado.

Aos professores e colaboradores da Universidade Fernando Pessoa (UFP) de PortoPortugal e da Escola de Enfermagem de Ribeirão Preto da Universidade de São Paulo (EERP/USP). Aprendi muito com vocês!

Aos professores da escola, onde essa pesquisa foi desenvolvida, por terem permitido a realização desse estudo. Pela recepção e disponibilidade. A participação de cada um de vocês tornou esse trabalho possível. Gratidão! 
"Quando a educação não é libertadora, o sonho do oprimido é ser o opressor."

Paulo Freire (2011) 


\section{RESUMO}

STEFANINI, J. R. Pesquisa-ação e práticas restaurativas para a prevenção da violência escolar: percepções dos professores. 2019. 96 f. Tese (Doutorado em Enfermagem Psiquiátrica) - Escola de Enfermagem de Ribeirão Preto, Universidade de São Paulo, Ribeirão Preto, 2019.

A violência escolar é um fenômeno complexo, dinâmico e multicausal, que envolve estudantes, professores, famílias e comunidade, como protagonistas e/ou vítimas da violência. Entende-se que a escola não é a única responsável pela produção da violência. No entanto, dependendo da maneira como a instituição lida com os problemas e conflitos instalados nesse contexto pode gerar as situações de violência escolar. Trata-se de um fenômeno que também tem suas raízes em questões de ordem sociais e econômicas, exigindo, programas de prevenção multidimensionais, com ações intersetoriais. A justiça restaurativa é uma estratégia para o enfrentamento da violência escolar, utilizada em diversos ambientes regidos pelas interações sociais, pois possibilita maneiras de resolução de conflitos no ambiente escolar. Esse estudo qualitativo, em que foi utilizado o método da pesquisa-ação, teve como objetivo compreender as percepções dos professores de uma escola pública da rede estadual de educação básica de Ribeirão Preto/SP sobre violência escolar, e desenvolver uma ação educativa para sua prevenção. A pesquisa foi desenvolvida em uma escola, que está inserida em um complexo contexto socioeconômico e cultural, com histórico de violência e dificuldades na condução do processo de ensino-aprendizagem. Participaram dessa pesquisa 10 professores do ensino fundamental e do ensino médio. Como instrumento de coleta de dados, optou-se pela observação participante, grupo focal e questionário. Os dados coletados, foram submetidos à análise temática indutiva e apresentados em duas etapas: momento investigativo e momento educativo. Reconheceu-se dificuldades e problemas prevalentes no ambiente escolar, experiências de violência escolar entre professores e estudantes e as estratégias que eles utilizavam para a prevenção da violência escolar. A partir dos problemas identificados foi realizado o Círculo de Cultura, como ação educativa. Essa ação foi elaborada baseada no modelo dialógico de Paulo Freire, que permitiu abordar a compreensão dos professores sobre os conceitos de conflitos e de violência escolar, promovendo reflexões sobre as habilidades direcionadas à gestão construtiva de conflitos e prevenção da violência escolar. Discute-se com base nestes resultados qualitativos a relevância do desenvolvimento de ações intersetoriais, visando a implementação de mecanismos de enfrentamento da violência escolar. Entende-se que não existe um recurso simplista para a prevenção da violência escolar, pois cada sociedade possui características e conflitos próprios, sendo necessária uma investigação ampla para saber qual seria a melhor atuação em determinada realidade escolar, na perspectiva de uma abordagem global com implicações na estrutura escolar. Mas é importante destacar o papel da escola no ensino/aprendizagem da transformação positiva do conflito, possibilitando a aprendizagem de formas de resolução não-violentas e, consequentemente, contribuindo para a melhoria das relações humanas.

Palavras-chave: Violência Escolar. Prevenção da Violência. Práticas Restaurativas. Pesquisa-ação. 


\begin{abstract}
STEFANINI, J. R. Action research and restorative practices for the prevention of school violence: teachers' perceptions. 2019. 96 f. Tese (Doutorado em Enfermagem Psiquiátrica) Escola de Enfermagem de Ribeirão Preto, Universidade de São Paulo, Ribeirão Preto, 2019.

School violence is a complex, dynamic and multi-causal phenomenon involving students, teachers, families and the community as protagonists and / or victims of violence. It is understood that the school is not alone responsible for the production of violence. However, depending on how the institution deals with the problems and conflicts installed in that context can generate situations of school violence. It is a phenomenon that also has its roots in social and economic issues, requiring multidimensional prevention programs with intersectoral actions. Restorative justice is a strategy for coping with school violence, used in several environments governed by social interactions, as it provides ways of resolving conflicts in the school environment. This qualitative study, using the action-research method, aimed to understand the perceptions of the teachers of a public school of the state school of basic education of Ribeirão Preto / SP on school violence, and to develop an educational action for its prevention. The research was developed in a school, which is inserted in a complex socioeconomic and cultural context, with a history of violence and difficulties in conducting the teaching-learning process. Ten primary and high school teachers participated in this research. As an instrument of data collection, we opted for participant observation, focus group and questionnaire. The collected data were submitted to thematic thematic inductive and presented in two stages: investigative moment and educational moment. Difficulties and problems prevalent in the school environment, experiences of school violence between teachers and students and the strategies they used for the prevention of school violence were acknowledged. From the problems identified, the Culture Circle was carried out as an educational action. This action was elaborated based on the dialogical model of Paulo Freire, which allowed to approach the teachers' understanding of the concepts of conflict and school violence, promoting reflections on the skills directed to the constructive management of conflicts and prevention of school violence. Based on these qualitative results, the relevance of the development of intersectoral actions is discussed, aiming at the implementation of mechanisms for coping with school violence. It is understood that there is no simplistic resource for the prevention of school violence, since each society has its own characteristics and conflicts, and a broad investigation is necessary to know what would be the best performance in a certain school reality, in the perspective of a global approach with implications in the school structure. But it is important to highlight the role of the school in the teaching / learning of the positive transformation of the conflict, enabling the learning of non-violent forms of resolution and, consequently, contributing to the improvement of human relations.
\end{abstract}

Keywords: School Violence. Prevention of Violence. Restorative Practices. Action research. 


\section{RESUMEN}

STEFANINI, J. R. Investigación-acción y prácticas restaurativas para la prevención de la violencia escolar: percepciones de los profesores. 2019. 96 f. Tese (Doutorado em Enfermagem Psiquiátrica) - Escola de Enfermagem de Ribeirão Preto, Universidade de São Paulo, Ribeirão Preto, 2019.

La violencia escolar es un fenómeno complejo, dinámico y multicausal, que involucra a estudiantes, profesores, familias y comunidades, como protagonistas y / o víctimas de la violencia. Se entiende que la escuela no es la única responsable de la producción de la violencia. Sin embargo, dependiendo de la manera en que la institución maneja los problemas y conflictos instalados en ese contexto puede generar las situaciones de violencia escolar. Se trata de un fenómeno que también tiene sus raíces en cuestiones de orden social y económico, exigiendo, programas de prevención multidimensionales, con acciones intersectoriales. La justicia restaurativa es una estrategia para el enfrentamiento de la violencia escolar, utilizada en diversos ambientes regidos por las interacciones sociales, pues posibilita maneras de resolución de conflictos en el ambiente escolar. Este estudio cualitativo, en que se utilizó el método de la investigación-acción, tuvo como objetivo comprender las percepciones de los profesores de una escuela pública de la red estadual de educación básica de Ribeirão Preto / SP sobre violencia escolar, y desarrollar una acción educativa para su prevención . La investigación fue desarrollada en una escuela, que está inserta en un complejo contexto socioeconómico y cultural, con histórico de violencia y dificultades en la conducción del proceso de enseñanza-aprendizaje. Participaron de esta investigación 10 profesores de enseñanza primaria y secundaria. Como instrumento de recolección de datos, se optó por la observación participante, grupo focal y cuestionario. Los datos recolectados, fueron sometidos al análisis temático inductivo y presentados en dos etapas: momento investigativo y momento educativo. Se reconoció dificultades y problemas prevalentes en el ambiente escolar, experiencias de violencia escolar entre profesores y estudiantes y las estrategias que ellos utilizaban para la prevención de la violencia escolar. A partir de los problemas identificados se realizó el Círculo de Cultura, como acción educativa. Esta acción fue elaborada basada en el modelo dialógico de Paulo Freire, que permitió abordar la comprensión de los profesores sobre los conceptos de conflictos y de violencia escolar, promoviendo reflexiones sobre las habilidades dirigidas a la gestión constructiva de conflictos y prevención de la violencia escolar. Se discute con base en estos resultados cualitativos la relevancia del desarrollo de acciones intersectoriales, visando la implementación de mecanismos de enfrentamiento de la violencia escolar. Se entiende que no existe un recurso simplista para la prevención de la violencia escolar, pues cada sociedad posee características y conflictos propios, siendo necesaria una investigación amplia para saber cuál sería la mejor actuación en determinada realidad escolar, en la perspectiva de un abordaje global con implicaciones en la estructura escolar. Pero es importante destacar el papel de la escuela en la enseñanza / aprendizaje de la transformación positiva del conflicto, posibilitando el aprendizaje de formas de resolución no violentas $\mathrm{y}$, consecuentemente, contribuyendo a la mejora de las relaciones humanas.

Palabras clave: Escuela Violence. Prevención de la violencia. Restora prácticas. Acción de investigación. 


\section{SUMÁRIO}

APRESENTAÇÃ

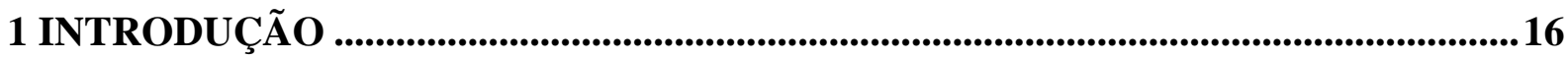

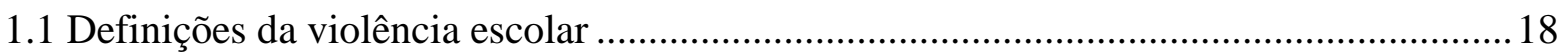

1.2 Violência escolar: um problema global ...................................................................... 21

1.3 Violência escolar: políticas públicas e programas de prevenção.....................................25

1.4 Programas de prevenção da violência escolar na perspectiva da justiça restaurativa ....... 30

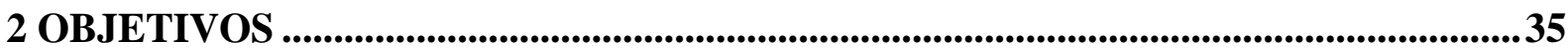

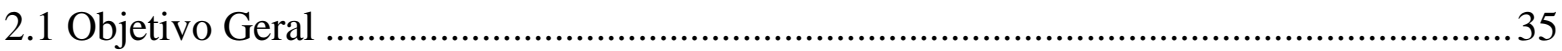

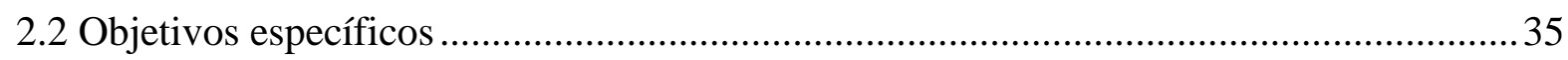

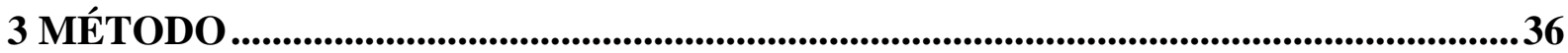

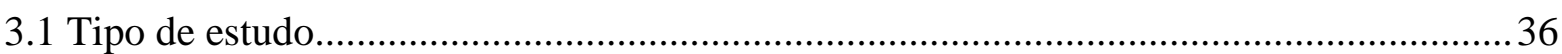

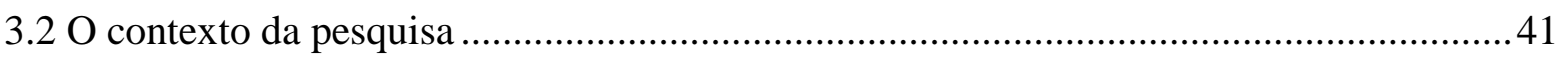

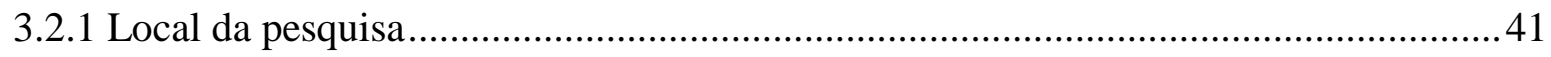

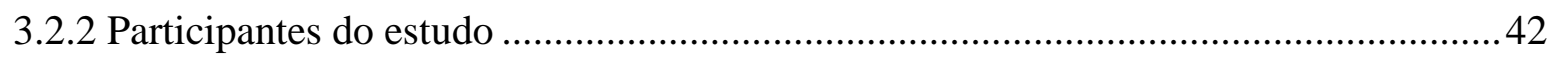

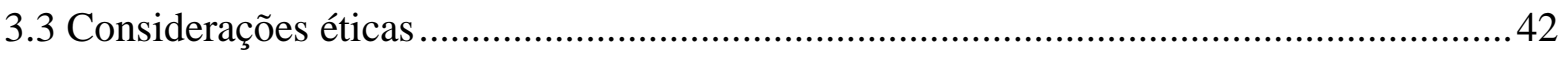

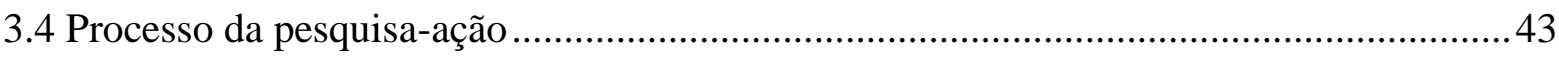

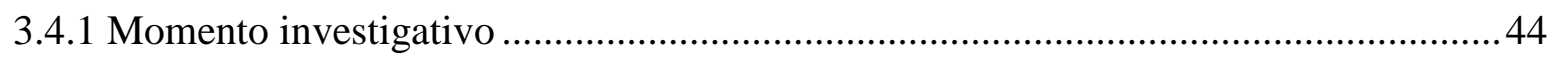

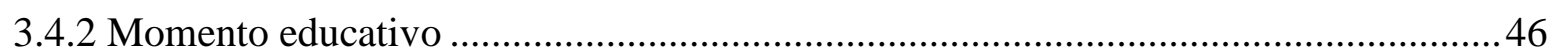

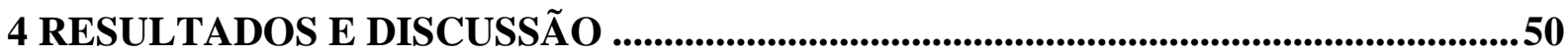

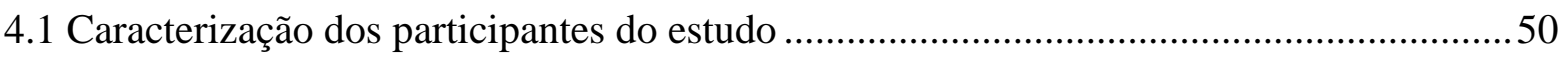

4.2 Dificuldades e problemas prevalentes no ambiente escolar ............................................52

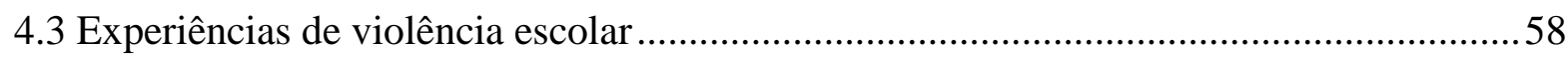

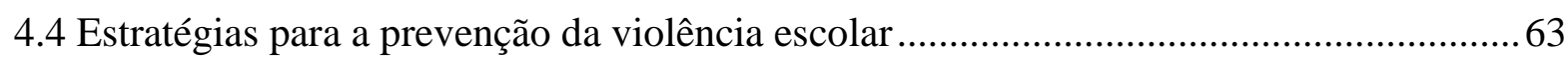

4.5 Ação educativa: habilidades para a gestão construtiva de conflitos e prevenção da

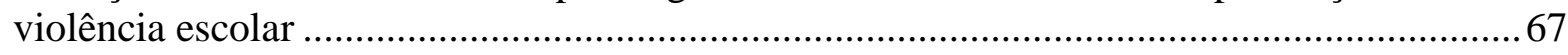

4.5.1 Compreensão dos professores sobre os conceitos de conflitos e de violência escolar 67

4.5.2 Habilidades para a gestão construtiva de conflitos e prevenção da violência escolar.73

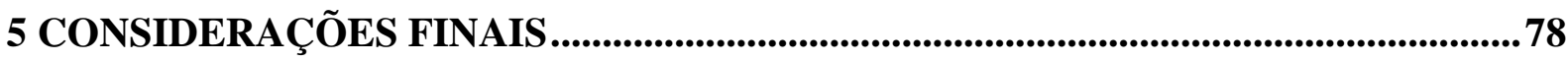

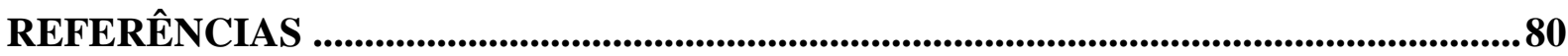

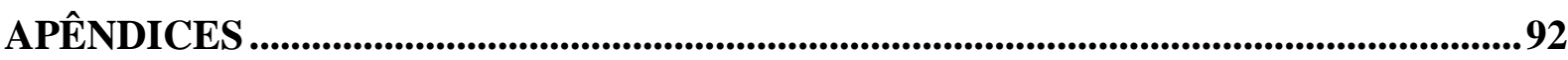

APÊNDICE A - Termo de Consentimento Livre e Esclarecido............................................. 92

APÊNDICE B - Questões Disparadoras do Grupo Focal ...................................................... 94

APÊNDICE C - Habilidades para a gestão construtiva do conflito e prevenção da violência escolar 


\section{APRESENTAÇÃO}

Sou enfermeira, especialista em saúde mental e atuante na linha de pesquisa de Promoção de Saúde Mental, com ênfase na prevenção da violência. O interesse em pesquisar a temática da violência e os diversos aspectos que permeiam esse fenômeno surgiu durante a graduação. Dos diversos tipos de violência, a que ocorre no ambiente doméstico foi a que mais me intrigou, provavelmente por entender a importância do contexto familiar no desenvolvimento humano. Sempre questionei o comportamento que envolve violência. Isso nunca fez sentido para mim.

Desde a graduação, tive interesse pela temática da violência e comecei a refletir mais sobre essas questões. Em 2009, meu Trabalho de Conclusão de Curso (TCC) ${ }^{1}$ foi sobre violência contra a mulher, realizado com vítimas dos diversos tipos de violência, o que me marcou profundamente. Durante as entrevistas, pude observar revelações de sentimentos, como vergonha, medo, raiva, acompanhados de manifestações de dor e choro, e eu percebi que tinha dificuldades para lidar com a situação. Não sabia o que dizer e como proceder. Enquanto aluna de enfermagem, entendi que os cuidados às vítimas de violência não envolvem somente as atividades assistenciais técnicas e prescritivas, postura que nós enfermeiros, infelizmente, adotamos com frequência.

Nunca mais me esqueci desses encontros e comecei a refletir sobre o quanto esse tema permaneceu ausente das reflexões em sala de aula durante a graduação. Motivada por essa questão, em 2010 pude realizar um curso de pós-graduação Lato Sensu em Saúde Mental, na Universidade de Ribeirão Preto (UNAERP), com objetivo de buscar conhecimentos específicos para atuação em promoção de saúde mental.

Durante esse curso de especialização, senti a necessidade de ampliar meus conhecimentos sobre a temática da violência. Comecei a participar do Grupo de Estudos Interdisciplinar sobre Violência (GREIVI), cadastrado no Diretório dos Grupos de Pesquisa do Brasil pelo Conselho Nacional de Desenvolvimento Científico e Tecnológico (CNPq) desde 2006, cuja líder é minha orientadora. No grupo, realizamos estudos teóricos sobre a temática, discussões de projetos de pesquisa, elaboração de artigos científicos e visitas técnicas a instituições especializadas. A partir da participação no GREIVI, surgiu a

\footnotetext{
${ }^{1}$ STEFANINI, J. R. Violência Contra a Mulher: relatos das mulheres atendidas pelo Centro de Referência e Atendimento à Mulher CRAM. 2009. Trabalho de Conclusão de Curso (Bacharel em Enfermagem) - Centro de Ensino Superior de Maringá, Paraná, 2009.
} 
oportunidade e interesse em conhecer um serviço de assistência à saúde mental para adolescentes no município de Ribeirão Preto - SP.

Desenvolvi estágio de observação, durante 6 meses (dezembro de 2010 a junho de 2011), no Ambulatório de Psiquiatria Juvenil (APQJ), localizado em um hospital público universitário do interior do Estado de São Paulo, com o propósito de conhecer o serviço de psiquiatria juvenil e identificar as principais necessidades da clientela. Nesse serviço, participei das reuniões semanais de equipe multiprofissional e das orientações e discussões dos casos de adolescentes atendidos, cujas queixas eram de transtornos mentais. Assim, foi possível observar a dinâmica dos atendimentos, características dos pacientes e transtornos, respostas aos tratamentos e as relações familiares, muitas vezes permeada por situações de violência.

A partir dessa experiência no APQJ, comecei a refletir sobre o quanto a violência afeta as relações e a saúde dos envolvidos, e como os serviços de saúde poderiam intervir, visando à prevenção dos diferentes tipos de violência por meio da articulação intersetorial. Motivada por essas questões, em 2012, ingressei no mestrado e realizei uma pesquisa com famílias de adolescentes com diagnóstico de Transtorno de Déficit de Atenção/Hiperatividade (TDAH), com ênfase nas percepções dos familiares sobre esse transtorno e as situações de violência que ocorrem no ambiente familiar e fora deste ${ }^{2}$.

Após as entrevistas com essas famílias, em que os pais relataram situações de violência familiar, bem como a ocorrência de violência no contexto escolar, comecei a questionar qual seria o trabalho da escola com esses adolescentes e suas famílias. Mas, antes de definir exatamente o que iria pesquisar no doutorado, atuei como professora no Centro Universitário Hermínio Ometto - FHO (UNIARARAS) e na Universidade Federal de São Carlos (UFSCar), nas áreas de Saúde Coletiva e Atenção em Saúde Mental.

Assim, em 2015, como professora em uma dessas universidades, acompanhei os estágios supervisionados na Atenção Primária à Saúde, especificamente em uma Unidade de Saúde da Família. Nesse período, pude observar a atuação do enfermeiro no Programa Saúde nas Escolas (PSE) e percebi que as ações desenvolvidas nas escolas eram direcionadas à avaliação antropométrica, atualização do calendário vacinal, detecção precoce de hipertensão arterial, avaliação oftalmológica, auditiva, nutricional e da saúde bucal. No entanto, a

\footnotetext{
${ }^{2}$ STEFANINI, J. R. Compreensões dos pais sobre o Transtorno de Déficit de Atenção/Hiperatividade em adolescentes e a exposição desses em situações de violência. 2014. 112 f. Dissertação (Mestrado em Ciências), Programa de Pós-Graduação em Enfermagem Psiquiátrica, Escola de Enfermagem de Ribeirão Preto da Universidade de São Paulo, Ribeirão Preto, 2014. Disponível em: <http://www.teses.usp.br/teses/disponiveis/ 22/22131/tde-19022015-192534/pt-br.php>. Acesso em: 02 nov. 2018.
} 
avaliação psicossocial dos estudantes não era realizada, tampouco ações de promoção de saúde mental e prevenção da violência.

A partir dessa experiência com o PSE e conversando com os profissionais do serviço, comecei a questionar sobre quais ações o enfermeiro poderia realizar para a prevenção da violência no contexto escolar? Como promover a articulação intersetorial? Será que a escola está preparada para lidar com a violência e questões de saúde mental? Será que esses profissionais conhecem estratégias de prevenção da violência?

Ainda em 2015, iniciei esta pesquisa com o Doutorado. Foi um grande questionamento pessoal, advindo da minha experiência profissional, que me levou a ouvir os professores para entender suas percepções sobre violência escolar e as estratégias que utilizam para sua prevenção. Após ouvir os professores, em 2017, busquei conhecimentos específicos para planejar uma ação de prevenção da violência escolar no campo, por meio da qual realizamos esta investigação.

Assim, desenvolvi um intercâmbio acadêmico por meio do convênio entre a Escola de Enfermagem de Ribeirão Preto (EERP) e a Universidade Fernando Pessoa (UFP) de Porto Portugal, coordenado pela orientadora desta tese de doutorado. O desenvolvimento dessa atividade acadêmica internacional, sob a supervisão da Profa. Dra. Ana Sani na UFP, foi possível devido ao Programa de Doutorado-sanduíche no Exterior, que custeou todo o período de intercâmbio, com bolsa de estudo pela Coordenação de Aperfeiçoamento de Pessoal de Nível Superior (CAPES).

Essa experiência de intercâmbio teve como objetivo realizar o aprofundamento teórico e de observação da prática acerca da temática "prevenção da violência escolar", com especialistas no assunto, para o aprimoramento da minha formação enquanto pesquisadora. $\mathrm{O}$ intercâmbio ocorreu de março a junho de 2017, período em que foi possível cursar disciplinas de Metodologia, Mediação Ofensor-Vítima e Justiça Restaurativa, Criminologia e Vitimologia, bem como participar de eventos internacionais sobre as temáticas de violência e saúde mental. Também foram elaborados dois manuscritos para publicação, sendo um artigo, intitulado "Avaliação do meio escolar: percepções dos profissionais de uma escola pública do interior de São Paulo", que está no prelo da Revista Lusófona de Educação, e um capítulo de livro, "Percepções de um grupo de professores sobre o enfrentamento da violência escolar", cuja obra "Abordagens contemporâneas de vitimação, violência e crime" tem lançamento previsto para abril de 2019.

Os resultados apresentados nesta tese buscam ressaltar a importância de subsídios para o desenvolvimento de programas de prevenção da violência escolar com atuação 
interdisciplinar, em que o enfermeiro é potencial protagonista dessas ações, promovendo articulação intersetorial.

Primeiramente, realizo breve introdução sobre o assunto, tratando da prevalência da violência escolar, dos fatores associados e das políticas públicas e programas de prevenção direcionados a esse tipo de violência. Descrevo os conceitos de violência escolar e estratégias para sua prevenção, a partir da perspectiva da justiça restaurativa, em "marco conceitual". Em "referencial teórico metodológico", conto os caminhos percorridos nesta pesquisa, assim como os conceitos metodológicos que a fundamentaram. Por fim, são apresentados os resultados e discussão e as considerações finais sobre este trabalho.

Os resultados são apresentados em dois tópicos, com intuito de trazer à luz as percepções dos professores sobre violência escolar e as estratégias de prevenção, bem como descrever os resultados da ação educativa a partir da perspectiva da justiça restaurativa. Como no percurso metodológico, os resultados desta tese são apresentados em dois momentos:

1) Momento investigativo - junto aos professores reflete-se sobre violência escolar e as estratégias de prevenção utilizadas por eles, buscando caracterizar tais experiências e apontar as necessidades e as dificuldades do cotidiano escolar.

2) Momento educativo - planejado e executado a partir do referencial de Paulo Freire (FREIRE, 2016), que possibilita a construção do conhecimento de forma participativa, por meio do pensamento crítico-reflexivo. Acredita-se que é possível transformar o ambiente escolar, produzir conhecimento a partir da prática, e ao mesmo tempo qualificar as interações e possibilidades para prevenção da violência escolar a partir da perspectiva da justiça restaurativa.

Meu principal desejo, com esta pesquisa, é deixar contribuições positivas para os professores, principalmente sobre estratégias para a prevenção da violência escolar. Hoje, finalizando a pesquisa, percebo que eu cresci e me fortaleci com essas experiências, motivo pelo qual partilhamos a partir daqui tudo o que foi vivenciado para a construção desta tese. 


\section{INTRODUÇÃO}

Todos os anos, 1,6 milhões de pessoas perdem a vida devido à violência e muitas sofrem ferimentos não fatais como resultados de agressões. Além disso, estima-se que a violência seja uma das principais causas de morte de pessoas entre 15 e 44 anos de idade em todo o mundo (WHO, 2014).

A violência é definida, segundo a Organização Mundial de Saúde (OMS), como o uso intencional da força física ou do poder, legítima ou em ameaça, contra si próprio, contra outra pessoa, ou contra um grupo ou uma comunidade, que resulte ou tenha grande possibilidade de resultar em lesão, morte, dano psicológico, deficiência de desenvolvimento ou privação (KRUG et al., 2002).

O Relatório Mundial sobre Violência e Saúde da OMS (KRUG et al., 2002) classifica didaticamente a violência em três tipos, segundo as características daqueles que cometem o ato violento: autoinfligida (comportamento suicida e autoabuso); interpessoal (da família e de parceiro íntimo, e comunitária) e/ou coletiva (social, política e econômica). Quanto à natureza dos atos violentos, estes podem ser caracterizados por abuso físico, sexual, psicológico e envolvendo privação ou negligência (KRUG et al., 2002).

A violência interpessoal comunitária ocorre entre pessoas que não possuem parentesco (consanguíneo ou não), embora possam ser conhecidas, geralmente fora de casa, como nas escolas, locais de trabalho, prisões e asilos (KRUG et al., 2002). Esse tipo de violência não se restringe a uma vítima específica, mas sim ao local onde ocorre e o tipo de relação existente entre a vítima e agressor (PERES et al., 2015).

Dentre os tipos de violência interpessoal comunitária, destacamos a violência escolar, que ocorre de forma isolada ou em grupo, dentro ou no entorno da escola, protagonizada por crianças e adolescentes, envolvendo estudantes, famílias, professores, diretores, funcionários, pessoas da comunidade ou estranhos (SCHERER, 2018). Trata-se de um fenômeno multifatorial e dinâmico, que acontece em todos os países do mundo, com efeitos traumáticos para as pessoas que a vivenciam, sendo uma violação dos direitos humanos básicos na escola (BRADSHAW et al., 2017).

A escola tem um papel formal relevante e integrativo na socialização dos indivíduos, sendo igualmente determinante para o seu desenvolvimento psicossocial (BRENNER; CARRANO, 2014). No entanto, o ambiente escolar também pode comprometer ambos os processos, dependendo da maneira como a instituição lida com os problemas e conflitos instalados nesse contexto. 
Os diversos desafios contemporâneos enfrentados pela escola, como os comportamentos problemáticos dos estudantes, incluindo o desrespeito entre os estudantes e professores, o não cumprimento de regras, o uso da violência e a depredação do patrimônio, a presença de armas de fogo na escola, a disseminação do uso de drogas e a expansão das gangues têm influenciado a rotina escolar (ABRAMOVAY; RUA, 2002; BECKER; KASSOUF, 2016; NUNES; CARIDADE; SANI, 2015). A escola se torna, assim, um local vulnerável, onde estudantes, famílias e professores se sentem inseguros e desprotegidos, podendo afetar importantes vínculos com a comunidade (ABRAMOVAY; RUA, 2002).

$\mathrm{O}$ aumento da vulnerabilidade à violência escolar está associado às características sociodemográficas do entorno da escola, à exposição à violência em outros espaços sociais, como no ambiente familiar, bem como à qualidade da interação dos professores com os alunos e ao grau de envolvimento dos pais na vida escolar dos filhos (NESELLO et al., 2014; TAVARES; PIETROBOM, 2016).

No estado de São Paulo, no período entre 2007 e 2009, a maioria dos registros da Secretaria de Educação do Estado de São Paulo (ROE/SEE-SP) sobre ocorrências de atos violentos ou crimes dentro das escolas estaduais foram de crimes contra o patrimônio. Os resultados desse estudo mostraram que os atos de vandalismo e de subtração de bens materiais ocorreram com mais frequência em escolas inseridas em bairros ou regiões de vulnerabilidade socioeconômica e, possivelmente, com maior nível de violência em geral (TAVARES; PIETROBOM, 2016).

A violência que ocorre no âmbito escolar tem como protagonistas estudantes e professores, e traz consequências para a saúde dos envolvidos. Os professores enfrentam diferentes problemas de saúde, como dores nas costas, problemas na voz e altas taxas de prevalência de transtornos mentais comuns (TCM) associados à violência escolar, sendo a categoria profissional que mais se afasta do trabalho por problemas de saúde (MACAIA; FISCHER, 2015; FILLIS et al., 2016; LIMA; COÊLHO; CEBALLOS, 2017). A violência escolar afeta a saúde de estudantes, sendo que na infância e adolescência exerce impactos sobre as habilidades socioemocionais, sobre o desempenho escolar e o engajamento em comportamentos de risco na vida adulta (TAVARES; PIETROBOM, 2016).

A violência escolar é um fenômeno complexo, sem fórmula rápida para sua solução. No entanto, é um fenômeno evitável, com muitas possibilidades de intervenções, desde que sejam estabelecidas com articulação intersetorial e com equipe multidisciplinar (SILVA; ASSIS, 2018). 
É preciso maior investimento na prevenção da violência escolar, sendo que as estratégias exitosas tendem a assumir uma perspectiva multidimensional, com intervenções em nível individual, didático e institucional, como também intervenções em nível primário, secundário e terciário, com os estudantes, professores e famílias/responsáveis (WOODBRIDGE et al., 2014; SCHULTES et al., 2014; BRADSHAW; WAASDORP; LEAF, 2015). Dessa forma, pesquisas sobre estratégias de prevenção da violência escolar, sobretudo que envolvam práticas democráticas na escola e negociação de conflitos, são importantes para apoiar a aprendizagem sobre o impacto de diferentes intervenções centradas no cotidiano escolar (SILVA; ASSIS, 2018). A comunidade escolar pode desenvolver ações que promovam um ambiente positivo, como, por exemplo, o desenvolvimento de habilidades pró-sociais, inserção de atividades curriculares para sensibilização e autorreflexão sobre violência, e gestão construtiva de conflitos (SILVA, 2018).

Diante disso, buscamos selecionar, na literatura, autores que se destacam em pesquisar e discutir a violência que ocorre no contexto escolar e ações de prevenção sob a perspectiva da justiça restaurativa. A proposta, ao aproximar-se desses autores, é delimitar o conceito de violência escolar e de prevenção, construindo um marco conceitual que auxilie a compreender e superar as dificuldades enfrentadas no ambiente escolar.

\subsection{Definições da violência escolar}

No Brasil, a discussão sobre violência escolar é relativamente recente, teve início a partir da década de 1990. Em países como França, Inglaterra, Noruega e Estados Unidos, estudos sobre essa temática já são realizados desde os anos de 1970 (OLWEUS, 1993; ABRAMOVAY; RUA, 2002; DEBARBIEUX; BLAYA, 2002; SPOSITO, 2003; SILVA; ASSIS, 2018).

A violência escolar tem sido reconhecida e nomeada de diferentes formas, com diversas conceituações e representações que estão entrelaçadas por essa terminologia (CHARLOT, 2002; DEBARBIEUX; BLAYA, 2002; ABRAMOVAY; RUA， 2002; STELKO-PEREIRA; WILLIAMS, 2010; SILVA; SALLES, 2010; PRIOTTO, 2011). Neste trabalho, no entanto, falamos sobre violência escolar, considerando as relações interpessoais como processo dinâmico, que envolve necessidades individuais, estilos próprios e diversas maneiras de ser, e quando são mal administradas, sobretudo no contexto escolar, evoluem para situações de conflitos e se agravam com a manifestação de violência física e/ou verbal 
(ORTEGA; DEL REY, 2002). Para falar desse tipo de violência, é fundamental que discutamos suas características e concepções.

As características da violência escolar mudam de acordo com o contexto social, político e econômico. No entanto, é descrito na literatura que esse tipo de violência se manifesta por meio de atos de agressão física e/ou psicológica contra alguém e caracteriza as relações interpessoais como de opressão, intimidação, medo e terror (SILVA; SALLES, 2010). Esse tipo de violência, também, pode ser visto sob a perspectiva de que os conflitos existentes na relação dos sujeitos que compõem este universo se configuram como comportamentos de oposição, manifestados, muitas vezes, pelo não cumprimento das regras e atividades escolares, desrespeito generalizado, depredação do patrimônio, furtos e comportamentos antissociais (NUNES; CARIDADE; SANI, 2015; SCHILLING; ANGELUCCI, 2016).

A violência escolar também pode ser analisada como consequência de um processo que tem início na família, com continuidade nos grupos e relações sociais do ambiente intra e extraescolar (GIORDANI; DELL'AGLIO, 2016). Há estudos que enfatizam a influência dos fatores externos, sobrepostos no território em que a escola está inserida, como a violência urbana e as desigualdades sociais, intensificando a violência escolar (LEMOS et al., 2016; VILALTA; FONDEVILA, 2018).

A falta de interesse dos estudantes nos conteúdos trabalhados em sala de aula e nos diplomas escolares também é descrita como um dos fatores relacionados à violência (SILVA; SALLES, 2010). Igualmente, existe análise da violência escolar na perspectiva da violência simbólica, praticada pela escola, que afeta, sobretudo, os alunos em condições sociais de vulnerabilidade, por meio da imposição de um poder arbitrário, intrínseco à ação pedagógica, com vistas à interiorização de saberes e valores da classe dominante, por meio de processos de legitimação, de controle e de sanções, e punições (BOURDIEU; PASSERON, 2014; LEMOS et al., 2016). Contudo, é importante compreender que quando o conflito acontece em contextos de desequilíbrio socioeconômico e divergências de identidades étnico-culturais, os indivíduos dos grupos minoritários ou com menos recursos se encontram numa situação de maior risco psicossocial do que aqueles de um grupo majoritário ou com mais recursos (POSSATO et al., 2016).

Essas concepções sugerem que a violência escolar está relacionada às condições estruturais da sociedade, e também se caracteriza por adotar práticas rígidas pautadas no poder e controle. Nesse contexto, os conflitos não são abordados de forma dialogada e 
democrática, afetando as relações interpessoais entre os indivíduos (ORTEGA; DEL REY, 2002).

O autor francês Bernard Charlot se destaca com conceituações relevantes para a temática violência escolar. Para o autor, a violência escolar ocorre em três tipos de manifestações: violência na escola, violência contra a escola e violência da escola (CHARLOT, 2002).

A violência na escola ocorre dentro do ambiente escolar ou em suas imediações (no portão de entrada ou na via pública em frente à escola), envolvendo professores, estudantes, diretores, funcionários, familiares, pessoas da comunidade e estranhos. Esse tipo de violência pode se manifestar por abusos físicos (empurrões, tapas, pontapés); abusos psicológicos (agressões verbais ou gestuais com o objetivo de aterrorizar, rejeitar, humilhar a vítima, restringir a liberdade ou, ainda, isolá-la do convívio social); abusos sexuais (relaciona-se ao ato ou ao jogo sexual que ocorre na relação heterossexual ou homossexual e visa estimular a vítima ou utilizá-la para obter excitação sexual e práticas eróticas, pornográficas e sexuais impostas por meio de aliciamento, violência física ou ameaças) e negligência (ausência, recusa ou deserção de cuidados necessários a alguém que deveria receber atenção e cuidados) (CHARLOT, 2002; SILVA; ASSIS, 2015).

O bullying é uma das expressões de violência na escola, caracterizado por um padrão de agressão persistente dentro de um relacionamento entre um ou mais estudantes contra outro(s), em que há nítido desequilíbrio de poder, tornando possível a intimidação da vítima. Essa forma de agressão tem origem na pré-escola e acompanha a pessoa ao longo da vida (CECIL; MOLNAR-MAIN, 2015).

A violência contra a escola é caracterizada por atos de vandalismo, tais como: incêndios, destruição, roubos ou furtos do patrimônio. E a violência da escola consiste em todo tipo de prática utilizada pela instituição escolar que prejudica os indivíduos que a frequentam como, por exemplo, o despreparo profissional, a falta de estímulos, o conteúdo divergente aos interesses dos alunos e do mercado de trabalho, os preconceitos e estereótipos, o abuso de poder e práticas punitivas (CHARLOT, 2002; SILVA; ASSIS, 2018).

Já os autores franceses Debarbieux e Blaya (2002), relacionam a violência escolar com os comportamentos antissociais e qualquer ato de transgressão e incivilidade que ocorra no ambiente escolar, como agressão física, verbal e sexual, desrespeito com os professores e entre alunos, vandalismo, roubos, porte de armas e uso de drogas. Para esses autores, é importante classificar a violência escolar para além de atos passíveis de punição penal, incluindo as vítimas de violência mais sutis e que se apresentam em maior número no espaço 
escolar. Dessa forma, são enfatizadas ações preventivas multidimensionais e não direcionadas às sanções e punições. Os autores distinguem conceitualmente as diferentes manifestações da violência escolar, ainda que seja uma tarefa difícil, e consideram importante categorizá-la, pois essa divisão permite visualizar as diferentes formas de tratamento do fenômeno (DEBARBIEUX; BLAYA, 2002).

Todos os autores afirmam a complexidade da violência que ocorre no âmbito escolar, assim como assumem que a categorização do fenômeno, ainda que realizada sob diferentes perspectivas, contribui para ações de prevenção mais eficazes. Ressaltamos que, embora exista um debate público, de forma abundante, referente à escola e à violência, ainda são incipientes os estudos sobre programas de prevenção e enfrentamento da violência escolar no Brasil que estejam contextualizados com a realidade local (SILVA; ASSIS, 2018).

\subsection{Violência escolar: um problema global}

Encontram-se diversos estudos recentes, em diferentes países e continentes, demonstrando que a violência escolar é um problema global (HA THI HAI LE et al., 2017; GARCÍA-GARCÍA et al., 2017; HELLFELDT; GILL; JOHANSSON, 2018), envolvendo desde países desenvolvidos até países em desenvolvimento, com impactos sociais, econômicos e relacionados à saúde dos indivíduos.

No continente asiático, China, especificamente Hong Kong, Vietnã e Indonésia são exemplos de países com prevalências entre $10,6 \%$ e $80 \%$ de diferentes tipos de violência escolar, incluindo bullying e cyberbullying. Como fatores associados à violência escolar, encontram-se jovens do sexo masculino, comunicação ineficiente na comunidade escolar, dificuldades nas relações entre a família e a escola, estudantes com baixos níveis de empatia e de comportamento pró-social, baixo vínculo e envolvimento do estudante com a escola e estudantes com problemas de saúde mental (CHAN; WONG, 2015; HA THI HAI LE et al., 2017; SAFARIA, 2016).

Na Europa, as prevalências de violência escolar variaram entre 7,3\% e 33\% na Suécia, Espanha e Portugal, sendo que o bullying genérico/tradicional mostrou-se o mais comum (GARCÍA-GARCÍA et al., 2017; COSTA et al., 2015; HELLFELDT; GILL; JOHANSSON, 2018). Em estudo longitudinal realizado na Suécia, as crianças vítimas de bullying, independente da duração ou persistência, mostraram episódios graves de sofrimento psíquico durante a trajetória de vida (HELLFELDT; GILL; JOHANSSON, 2018). Na Espanha, dependendo da idade dos estudantes, o bullying se manifestou de maneira expressiva, com 
aumento desse tipo de violência entre os adolescentes. Nesse contexto, o bullying social e o bullying verbal foram as formas mais comuns de exposição à violência experimentadas pelos estudantes (SÁNCHEZ-QUEIJA; GARCÍA-MOYA; MORENO, 2017; GARCÍA-GARCÍA et al., 2017).

Em Uganda, país do continente africano, as prevalências de violência escolar variaram de 13\% a 21,1\% (WANDERA et al., 2017; THUMANN et al., 2016). Os fatores associados à ocorrência de violência escolar foram o baixo desempenho acadêmico dos estudantes, aumento dos níveis de problemas de saúde mental, baixa conectividade escolar, exposição à violência interparental e estudantes de baixa classe econômica (WANDERA et al., 2017; THUMANN et al., 2016).

$\mathrm{Na}$ América do Norte, as prevalências de violência escolar variaram entre $48 \%$ e 79,6\% nos Estados Unidos e Canadá, sendo que a vitimização de bullying e agressões físicas entre estudantes mostraram-se mais comuns (FINKELHOR et al., 2014; NAPOLETANO, 2015). Em um estudo realizado nos Estados Unidos, os adolescentes, de 10 a 17 anos, tiveram maiores taxas de exposição a todos os tipos de vitimização na escola, quando comparado às crianças de 5 a 9 anos. As características da comunidade em que a escola está inserida, com atividade criminal, armas, gangues e ataques policiais também estavam relacionadas a todos os tipos de violência escolar, incluindo a venda de drogas dentro da escola (FINKELHOR et al., 2014). No Canadá, estudo mostrou que a desigualdade de renda e a desorganização social estão relacionadas à violência escolar, pois convergem para o baixo sentimento de pertencimento entre os indivíduos da comunidade e aumentam o sentimento de privação (NAPOLETANO, 2015).

No México, as prevalências de violência escolar variaram de $24,4 \%$ a $43 \%$, sendo que o vandalismo relacionado aos comportamentos antissociais dos estudantes e o bullying mostraram-se mais frequentes (RAMOS-JIMÉNEZ et al., 2017; VILALTA; FONDEVILA, 2018). Dentre os fatores associados ao aumento da prevalência do bullying, no México, destacou-se a alta imigração na região de fronteira com os Estados Unidos. Já a diminuição da prevalência e incidência do bullying estava relacionada à idade e ao grau acadêmico, sendo que no último ano do ensino médio e na universidade o bullying verbal e físico diminuíram (RAMOS-JIMÉNEZ et al., 2017). Ainda no México, um estudo realizado com estudantes do ensino médio sobre prevalência do vandalismo escolar mostrou que os fatores associados a esse tipo de violência foram o uso de drogas, afiliação a gangues, maior tempo dedicado a assistir televisão (TV) e a valorização dos comportamentos de transgressão das regras escolares. Por outro lado, a percepção dos estudantes do tratamento recebido pelos 
professores reduz a propensão para cometer um ato de vandalismo contra a escola (VILALTA; FONDEVILA, 2018).

Estudo realizado em 15 países da América Latina e Caribe, com estudantes do ensino médio, identificou prevalências entre $17 \%$ e $39 \%$ de violência escolar, principalmente vitimização por bullying. Houve diferenças significativas dos tipos de bullying relatados por meninos e meninas, sendo que as meninas foram vítimas do bullying relacionado às características físicas e aparência. Já com os meninos, os tipos de bullying foram relacionados à agressão física, manifestadas por chutes e empurrões. Os resultados desse estudo sugerem que o bullying é uma ocorrência comum entre os adolescentes nas Américas (McCLANAHAN; McCOY; JACOBSEN, 2015).

$\mathrm{Na}$ América Latina, focamos nossas buscas em estudos brasileiros. No nordeste do Brasil, especificamente nos estados da Bahia e da Paraíba, as prevalências variaram entre $28 \%$ e 29,5\% de vitimização de violência escolar (VILA NOVA; SENA; OLIVEIRA, 2015; MARCOLINO et al., 2018). Dentre os tipos de violência sofrida pelos estudantes, tanto para as meninas como para os meninos, o bullying psicológico predominou, com tais situações: espalhar fofoca, excluir de atividades, xingar, ameaçar e ridicularizar. Como fatores associados à prática do bullying, encontram-se os comportamentos de risco, como consumo de fumo, álcool e outras drogas (MARCOLINO et al., 2018).

Ainda no nordeste brasileiro, entre adolescentes a prevalência de prática de bullying, com alto risco para agressão direta, agressão relacional e vitimização, foi de 45,61\%, sendo que esses tipos de violência estavam associados ao consumo de álcool/drogas (MOTA et al., 2018). Já na região Norte do Brasil, especificamente no estado de Rondônia, estudo sobre o consumo de substância por estudantes, entre 12 e 19 anos, encontrou prevalências de 49,6\%, $17,5 \%$ e 5,3\% para álcool, tabaco e outras drogas respectivamente, sendo que o consumo exagerado de bebida alcoólica estava associado a brigas ou ausência na escola nos últimos 30 dias (ELICKER et al., 2015).

No sudeste do Brasil, estudo realizado com estudantes do ensino fundamental sobre vitimização por bullying encontrou prevalência de $7,8 \%$, sendo que os fatores associados a esse tipo de violência escolar foram o menor nível de escolaridade das mães, exposição à violência familiar, faltar às aulas sem avisar aos pais, comportamentos de risco como fumar, experimentar drogas e relações sexuais (MELLO et al., 2016). No estado de São Paulo, especificamente em um município do noroeste paulista, estudo realizado com adolescentes da rede pública de ensino encontrou prevalência de bullying de 62,34\% de vítimas do sexo 
feminino, sendo que a forma mais prevalente de intimidação sofrida foi a verbal (GARBIN; GATTO; GARBIN, 2016).

A exposição à violência escolar não ocorre somente entre os estudantes. Os professores também estão suscetíveis a diversas dificuldades no cotidiano escolar, bem como às situações de violência. No nordeste do Brasil, um estudo realizado com professores da educação básica de Recife-PE sobre violência escolar e problemas relacionados à saúde mental, encontrou prevalência de $42,9 \%$ de vitimização de professores, sendo que a agressão verbal e/ou a ameaça contra o professor mostraram-se mais predominantes se comparadas à agressão física. Esse estudo identificou ainda que a agressão física e a agressão verbal contra o professor, a agressão ou ameaça com arma de fogo ou arma branca, o tráfico e o consumo de drogas na escola estavam associados ao desenvolvimento de transtornos mentais comuns (TCM) entre os professores (LIMA; COÊLHO; CEBALHOS, 2017).

Em Londrina, região Sul do Brasil, estudos com professores da educação básica encontraram prevalência de 8,4\% (KOGA et al., 2015) a 8,7\% (MELANDA et al., 2018) de vitimização de violência escolar. Dentre os tipos de violência mais relatados pelos professores, nos últimos 12 meses, destaca-se o fato de terem recebido insultos ou gozações de alunos, humilhações, insultos ou gozações de colegas ou superiores. Os resultados desses estudos mostraram que o relacionamento precário entre professor e aluno, a violência em ambiente escolar e outras características do trabalho são fatores associados ao sofrimento psíquico entre os professores, inclusive com o desenvolvimento da Síndrome de Burnout (KOGA et al., 2015; MELANDA et al., 2018).

No estado de São Paulo, estudo realizado com professores da rede estadual de ensino sobre violência nas escolas encontrou prevalência de $51 \%$ de vitimização de professores, sendo que $44 \%$ dos professores sofreram agressão verbal na instituição, $9 \%$ discriminação, $8 \%$ bullying, $6 \%$ furto/roubo e $5 \%$ agressão física. Os resultados dessa pesquisa indicaram que as agressões nas escolas, verbais ou físicas, aumentaram nos últimos três anos. Como fatores associados à ocorrência de violência, os professores relataram a educação em casa, consumo de álcool e drogas, conflitos entre os estudantes e falta de policiamento (APEOESP, 2017).

Percebe-se, pelos estudos encontrados, que a violência escolar tem altas taxas de prevalência, diversos fatores associados e consequências negativas para os estudantes, professores e todos os envolvidos. A violência escolar é motivada por uma multiplicidade de fatores, incluindo aspectos culturais, sociais, econômicos e políticos, circunstâncias que 
evidenciam a importância do planejamento e implementação de programas multidimensionais de prevenção da violência escolar.

\subsection{Violência escolar: políticas públicas e programas de prevenção}

As políticas públicas relacionadas à prevenção da violência escolar tiveram início no final da década de 1990, com os primeiros documentos normativos internacionais elaborados pela Organização das Nações Unidas (ONU) e Organização das Nações Unidas para a Educação, a Ciência e a Cultura (UNESCO), com intuito de promover ações de prevenção da violência escolar, respeitando os princípios constitutivos de uma cultura de paz (POSSATO et al., 2016). Esse debate a nível mundial surgiu devido à intensidade das ocorrências de violência nas escolas, tornando-se necessárias intervenções efetivas por meio de políticas públicas.

Apesar da importância da elaboração e manutenção de políticas públicas direcionadas à prevenção da violência escolar, existem divergências epistemológicas e políticas em relação à definição da violência escolar. Isso ocorre devido ao caráter amplo da definição do fenômeno, que pode ir além de uma abordagem repressiva. Nessa perspectiva, as políticas públicas passam a tratar da violência considerando a redução do número de vítimas e o grau de vitimização, não apenas o número de pessoas punidas e/ou presas (DEBARBIEUX; BLAYA, 2002). Desse modo, as intervenções de prevenção da violência escolar tornam-se mais abrangentes, com ações centradas nos riscos, não apenas no combate à violência e criminalidade, mas também para promoção de saúde, incluindo o acesso à educação de qualidade, ao emprego, à moradia, atendendo às demandas do indivíduo.

As experiências de vários países, como França, Reino Unido, Japão e Estados Unidos, no combate e prevenção da violência escolar têm sua eficácia comprovada a partir de ações determinadas por políticas públicas, vinculadas à pesquisa de base e à pesquisa aplicada, em que unem pesquisadores, políticos e profissionais da área para o enfrentamento deste fenômeno (DEBARBIEUX; BLAYA, 2002).

Em países da Europa, como, por exemplo, Reino Unido (HUTCHINGS et al., 2013) e Áustria (SCHULTES et al., 2014), existem programas para prevenção da violência escolar interligados, abrangentes e com evidências efetivas, baseados no desenvolvimento dos pais, professores e estudantes. Esses programas de prevenção primária da violência são desenvolvidos nas escolas por meio de políticas públicas, que trabalham a aprendizagem cognitiva social, auto eficácia e construção de relacionamentos, com objetivo de reduzir o 
comportamento agressivo e a violência escolar. Tais programas são: Incredible Years® Sessão para pais, professores e crianças (HUTCHINGS et al., 2013) e Social Competence Program (VISC), este último foi desenvolvido pelo Ministério Federal de Educação da Áustria (SCHULTES et al., 2014).

No continente asiático, especificamente na Indonésia, estudo realizado em duas escolas públicas, com alto nível de agressão verbal entre os 844 estudantes, utilizou o aconselhamento de Análise Transacional (AT) para resolução de questões relacionadas à agressão verbal. Trata-se de uma abordagem cognitivo comportamental, que conseguiu reduzir os comportamentos agressivos e aumentar o ajuste social entre os adolescentes (NETRAWATI et al., 2016). A implementação da AT nessas escolas ocorreu a partir de uma parceria entre a universidade e a gestão pública, o que destaca a importância de políticas públicas como marco regulatório para a prevenção da violência escolar.

Nas Américas, os Estados Unidos sobressaem no que se refere aos programas de prevenção da violência escolar (SILVA, 2018). Existem diferentes programas de prevenção implementados, que passam por avaliação contínua para sua manutenção. Esses programas foram criados consoantes às políticas públicas, baseados em pesquisas e evidências, direcionados à prevenção da violência escolar, com ênfase no enfrentamento do bullying, no treinamento de habilidades pró-sociais, no gerenciamento de comportamento agressivo e no envolvimento da família com a escola. Como exemplo desses programas estão: Olweus Bullying Prevention Program (OLWEUS, 1993), referência mundial no combate ao bullying; Families and Schools Together (FAST) (FEARNOW-KENNEY; HILL; GORE, 2016); e Peaceful Alternatives to Tough Situations (PATTS) (STAECKER et al., 2016).

No Canadá, o Fourth R Programs é uma abordagem de prevenção da violência escolar universal, desenvolvido por um grupo de pesquisadores e profissionais da área de saúde mental, com objetivo de promover relacionamentos saudáveis e reduzir comportamentos de risco, envolvendo o treinamento dos profissionais da escola, estudantes, família e comunidade (CROOKS et al., 2013). Esse programa atende demandas estabelecidas pelas políticas públicas vinculadas ao Ministério e Departamento de Educação (CROOKS et al., 2013).

$\mathrm{Na}$ América Latina, pesquisa bibliográfica sobre programas de prevenção da violência escolar revelou que países como Argentina, Chile, Colômbia, Equador, Venezuela, Brasil e Peru possuem, desde os anos 2000, programas que visam à convivência escolar e à resolução de conflitos por meio da mediação (POSSATO et al., 2016). Esses programas foram implementados a partir de políticas públicas, especialmente do Ministério da Justiça e Educação. No entanto, tal pesquisa apontou que não há evidências científicas que possibilitem 
maior compreensão sobre o alcance desses programas nas realidades escolares (POSSATO et al., 2016).

Examinando especificamente as políticas públicas e programas para a redução da violência escolar no Brasil, verificam-se iniciativas do Ministério da Justiça na década de 2000, com intuito de combater o envolvimento sistemático de jovens em práticas criminosas (GONÇALVES; SPOSITO, 2002). Nesse período, foi designada uma comissão de especialistas da Secretaria de Direitos Humanos a elaborar diretrizes para a diminuição das manifestações violentas nas escolas. Um dos primeiros resultados dessa parceria foi o "Programa Paz nas Escolas", desenvolvido em 14 estados brasileiros. Esse programa focou na formação de professores e de policiais para lidarem com o tema da violência nas escolas (GONÇALVES; SPOSITO, 2002).

Desde então, outros programas e projetos têm sido desenvolvidos pelo governo federal, governos estaduais, municipais, bem como ações realizadas por organizações nãogovernamentais e outras instituições diversas (POSSATO et al., 2016). De modo geral, essas ações do poder público no Brasil são implementadas com a finalidade de prevenir e enfrentar a violência escolar, transitando entre medidas de caráter educativo e da área de segurança (SILVA; ASSIS, 2018). Mas, diante da complexidade e dificuldades que permeiam a violência escolar, são fundamentais políticas públicas para o seu enfrentamento de maneira efetiva e à luz de marcos regulatórios. Assim, as intervenções para o enfrentamento do fenômeno, ao serem conduzidas de forma legítima, oficializada e intersetorial, apresentam mais possibilidades de sucesso (MELLO, 2018).

No Brasil, existem alguns marcos regulatórios e leis federais ou estaduais que são importantes referências enquanto garantia e implementação de direitos protetivos de crianças e adolescentes, que envolvem o universo escolar, como, por exemplo, a Lei $\mathrm{n}^{\circ} 8.069$ de 1990, Estatuto da Criança e do Adolescente (ECA) (BRASIL, 1990). Essa lei, além de orientar as famílias e os profissionais de diversas áreas de conhecimento, estabelece um conjunto de diretrizes que asseguram às crianças e aos adolescentes condições adequadas para o seu desenvolvimento, livre de qualquer forma de negligência, discriminação, exploração, violência, crueldade e opressão (MOREIRA, SALUM; OLIVEIRA, 2016).

Por outro lado, a falta de conhecimento sobre o ECA tem levado a interpretações equivocadas deste marco legal por parte da comunidade, dos profissionais e da escola, afetando o ensino. Além disso, muitos dos desafios enfrentados pela escola, como o comportamento agressivo e/ou antissocial manifestados pelos estudantes, tornaram-se mais frequentes após a implementação do ECA (MELLO, 2018). Diante dessas dificuldades, mais 
recentemente, foi decretada a Lei $\mathrm{n}^{\circ} 13.431$ de 2017, que altera a lei do ECA, estabelecendo o sistema de garantia de direitos da criança e do adolescente vítima ou testemunha de violência. Essa lei cria mecanismos para prevenir e coibir a violência, seja ela física ou psicológica, incluindo o bullying, contra a criança e adolescente (BRASIL, 2017).

Com objetivo de subsidiar as instituições de ensino no combate e prevenção de problemas que afetam o desenvolvimento de crianças e adolescentes, em 2010, o Conselho Nacional de Justiça (CNJ) criou o "Programa Justiça nas Escolas". Em parceria com as Coordenadorias de Infância e Juventude dos Tribunais de Justiça de todo o país, associações de magistrados e órgãos ligados à educação, o programa propõe debater temas como combate às drogas, bullying, violência nas escolas, evasão escolar, prevenção de doenças sexualmente transmissíveis e cidadania. Os trabalhos desenvolvidos pelo programa contam com a participação de juízes, professores, educadores, técnicos em psicologia e serviço social, alunos e pais. Por meio dessas discussões, busca-se estimular a articulação intersetorial, especialmente entre as instituições de Justiça e de Educação (CONSELHO NACIONAL DE JUSTIÇA, 2010).

O Programa Justiça nas Escolas lançou duas versões da Cartilha Justiça nas Escolas Bullying, sendo uma versão simplificada para professores e profissionais de ensino. A cartilha trata da violência física ou psicológica contra pessoa incapaz de se defender. Esse material tem o intuito de ajudar pais e educadores a prevenir o problema do bullying nas suas comunidades e escolas (SILVA, 2010).

Também foi criada, no Brasil, como política pública de prevenção da violência escolar, a Lei $n^{\circ} 13.185$ de 2015, que institui o Programa de Combate à Intimidação Sistemática (Bullying). Esse programa tem o objetivo de combater e prevenir a prática de intimidação sistemática em toda a sociedade, tornando-se um marco jurídico no enfrentamento ao bullying (BRASIL, 2015). A lei constitui-se de esclarecimentos sobre conceitos e caracterização desse tipo de violência, além de diretrizes, orientações e informações destinadas aos profissionais das escolas, famílias e comunidades. Dentre suas diretrizes, a lei esclarece e direciona a capacitação de docentes e equipes pedagógicas, com objetivo de promover a cidadania, a capacidade empática e o respeito a terceiros, nos marcos de uma cultura de paz e tolerância mútua (BRASIL, 2015).

Levando em consideração a importância das políticas públicas de prevenção da violência escolar e a necessidade de articulação intersetorial, buscou-se saber quais são as políticas e programas de prevenção da violência escolar implementados no estado de São Paulo, pois a escola campo desta pesquisa está localizada na região noroeste do estado. 
Em 2010, o governo do Estado de São Paulo implantou, por meio da Secretaria de Estado da Educação, o Sistema de Proteção Escolar (SPE). Trata-se de uma política cujo objetivo é instaurar na rede pública de escolas estaduais paulistas ações para prevenir, mediar e resolver conflitos em unidades localizadas em regiões com condições social e econômica de vulnerabilidade (MARTINS; ALVES, 2018). Dentre as ações desenvolvidas pelo SPE, está a criação da função de Professor Mediador Escolar e Comunitário (PMEC), o qual atua nas escolas e comunidades. Também houve a divulgação do Manual de Proteção Escolar e Promoção da Cidadania, material que integra o SPE e tem como finalidade subsidiar a construção de uma cultura de paz para uma realidade social menos contraditória e conflituosa (CUNHA; MONTEIRO, 2016; MARTINS; ALVES, 2018).

Embora o Estado de São Paulo, atualmente, disponha de mais de três mil PMECs atuando na rede pública de escolas estaduais, ainda existem problemas estruturais que prejudicam a implementação do programa, como a falta de conhecimento dos profissionais acerca da comunidade onde a escola se insere, déficit de informações sobre processos de mediação de problemas e conflitos em escolas, especialmente em relação àquelas em condições sociais e econômicas de vulnerabilidade (POSSATO et al., 2016). Além disso, os profissionais possuem dificuldades para lidarem com valores sociais complexos, incluindo questões culturais, de gênero, opções sexuais, religião, condições econômicas, novas configurações familiares que se refletem na escola e as influências negativas do contexto (usos e tráfico de droga; alcoolismo; brigas) (MARTINS; ALVES, 2018).

Essas dificuldades estão relacionadas também às políticas públicas que, em sua maioria, são desenvolvidas pela área da justiça e não no âmbito da educação e/ou saúde. Dessa forma, os programas de prevenção da violência escolar junto à Secretaria de Segurança Pública tornam a educação caso de polícia e apontam para a judicialização da educação (POSSATO et al., 2016). Por outro lado, existe uma expansão de conhecimentos acerca da prevenção da violência escolar, envolvendo pesquisadores e profissionais da área da saúde. Isso torna-se evidente com o desenvolvimento do Programa de Intervenção e Educação em Saúde Antibullying (PIESA), elaborado por enfermeiros, baseado em evidência nacionais e internacionais. Nesse programa, são realizadas atividades de promoção de saúde nas escolas e ações de prevenção e enfrentamento da violência escolar. O PIESA abrange a possibilidade de atuação de profissionais da saúde, como do enfermeiro, na prevenção e enfrentamento desse tipo de violência (YOSHINAGA et al., 2018).

Apesar da implementação de programas interventivos para prevenção da violência escolar, ainda existem dificuldades e a influência das questões culturais e diversidades como 
passíveis de reflexo em qualquer setor da sociedade, gerando conflitos, sobretudo, pela falta de diálogo nas relações interpessoais dentro dos contextos educativos. Desse modo, é percebida a importância de, nas políticas nacionais, serem pensadas questões quanto à formação dos profissionais, especialmente da saúde e da educação, para implementação de ações de prevenção da violência escolar. Estudo recente aponta o uso da mediação interpessoal e de programas de formação para profissionais da educação sobre conflitos e outras causas difusas que repercutem negativamente na convivência escolar, como possibilidades para prevenção da violência escolar (TOGNETTA; DAUD, 2018).

\subsection{Programas de prevenção da violência escolar na perspectiva da justiça restaurativa}

Neste trabalho, consideramos a justiça restaurativa como uma possibilidade para prevenção da violência escolar. Tal fenômeno acontece em todos os países, de diversas formas, graus de intensidade e afeta diferentes fases do desenvolvimento humano, com prejuízos físicos, psicológicos, sociais e comportamentais para o indivíduo (BRADSHAW et al., 2017).

O conceito da Justiça Restaurativa é próprio das ciências sociais, especialmente a do direito civil (MELLO, 2018). Essa denominação é atribuída a Albert Eglash, um psicólogo que, na década de 50, trabalhava com adultos e jovens envolvidos no sistema de justiça criminal dos Estados Unidos. A partir dessas experiências, Eglash, na década de 70, descreveu que havia três propostas ao crime: a retributiva, baseada na punição; a distributiva, focada na reeducação; e a restaurativa, cujo fundamento seria a reparação (PINTO, 2010).

Logo, foi no final da década de 70 e início da década de 80 que o movimento internacional influenciou o reconhecimento e desenvolvimento de práticas restaurativas. Esse movimento iniciou-se no Canadá e na Nova Zelândia, a partir de resultados de estudos de antigas tradições, que se baseavam em diálogos pacificadores e construtores de consensos, utilizadas pelos antigos povos desses países e por culturas tribais africanas (ORSINI; LARA, 2013).

No Brasil, as iniciativas do modelo restaurativo se consolidaram a partir da Resolução 2.002/12 do Conselho Econômico e Social da ONU, e têm avançado nos últimos 10 anos (PINTO, 2010). A Justiça Restaurativa é um método complementar de tratamento de conflitos, que possibilita de forma participativa a construção de formas de resolução de conflitos (ORSINI; LARA, 2013). As práticas restaurativas são aplicadas a qualquer tipo de 
conflito, como na família, na comunidade, na escola, no ambiente de trabalho e no sistema de justiça (MARTINS; MARQUES; GUIMARÃES, 2016).

Compreende-se conflito como:

[...] inerente ao ser humano e pode representar uma oportunidade de autoconhecimento para estabelecer o diálogo e cooperação. A convivência entre pessoas com diferentes, idades, origens, sexo, etnias, condições socioeconômicas e culturais, com interesses, necessidades e vontades diversas, pode tornar a escola um ambiente palco de diversos conflitos. Estes, se bem manejados gerenciados de forma construtiva, podem levar à restauração das relações, ao compromisso e à colaboração. Do contrário, levam ao desajuste nos relacionamentos às relações interpessoais disfuncionais e à violência (SCHERER, 2018, p. 5).

É importante apresentar, no entanto, duas conotações do conflito, negativa ou positiva. No sentido negativo, o conflito é caracterizado por uma relação interpessoal indesejável, disfuncional, com hostilidade no exercício de poder um sobre o outro. Já o conflito na conotação positiva é indispensável para evolução, gerando energia criativa e oportunidade de crescimento pessoal (WAGNER, 2018).

Entende-se que a abordagem dos conflitos nas práticas restaurativas está relacionada à promoção de uma cultura da paz, construída por meio de ações que possibilitam aprendizado e mudança de comportamento, superando a competição, visando ao fortalecimento do diálogo e ao respeito às diferenças (LIMA; SILVA, 2017). Segundo as autoras, é necessário superarmos uma cultura de disputa existente e disseminada na sociedade, como exemplo, elas citam a relação de amor/ódio dos brasileiros com jogo de futebol. Essa cultura com frequência se consuma com atitudes violentas. A mudança cultural não ocorre em um tempo determinado e de uma única vez. Além disso, normas e regras, por si sós, não modificam cultura. Portanto, é importante traçar alternativas para mudanças de comportamentos (LIMA; SILVA, 2017).

As alternativas para resolução de conflitos perpassam por diversos modelos, que enfatizam abordagens punitivas, retributivas e práticas restaurativas, envolvendo dimensões comportamentais (MARTINS, MARQUES; GUIMARÃES, 2016). Dentre as práticas restaurativas, a valorização de comportamentos de assertividade e cooperação como recurso para gestão de conflitos, resulta da combinação da dupla preocupação em atingir os interesses/objetivos próprios e a preocupação em satisfazer os interesses/objetivos do outro. Essas preocupações refletem na maneira como o indivíduo se comporta para a gestão de conflitos, que são: acomodação, compromisso, colaboração, evitamento e competição (CUNHA et al., 2018). Em relação ao comportamento de acomodação, priorizam-se os 
interesses do outro em detrimento do seu próprio. Compromisso refere-se à busca de um acordo entre os envolvidos, assumindo as responsabilidades de cada um. No comportamento colaborativo, objetiva-se a satisfação dos interesses dos envolvidos buscando um acordo conjunto, trabalhando, inclusive, nas expectativas que são trazidas. No evitamento, o comportamento principal é de fuga do conflito ou do problema, ignorando ou negligenciando os interesses dos envolvidos. Já a competição foca em satisfazer os interesses próprios de maneira unilateral (CUNHA; MONTEIRO; LOURENÇO; MOREIRA, 2018).

O modelo restaurativo, contrário a lógica punitiva, possibilita uma prática educacional com a promoção dos diálogos sobre diversos temas nas escolas, inclusive conflitos e violência (LIMA; SILVA, 2017; WAGNER, 2018). Esse modelo baseia-se em um processo de consenso entre as partes inseridas em um determinado contexto, em que vítima e autor participam ativamente na construção de soluções para que haja reintegração social, ocorra a restauração das relações, bem como sejam supridas as necessidades dos envolvidos de modo restaurativo (PINTO, 2010; MARTINS; MARQUES; GUIMARÃES, 2016).

A gestão construtiva de conflitos é uma estratégia restaurativa que enfatiza a mudança da reação psicológica, em que os indivíduos se responsabilizam por suas decisões, deixam de se proteger de erros, de julgamentos e de culpabilizar o outro (CUNHA; LEITÃO, 2016). Existem alguns aspectos fundamentais para a efetividade da gestão construtiva de conflitos, que são a comunicação, a escuta e a compreensão acerca das percepções dos envolvidos, assim como o contexto em que estão inseridos e a origem do conflito (MCKIBBEN, 2017).

Dentre as abordagens de gestão construtiva de conflitos estão a negociação e a mediação. A negociação consiste no processo de resolução do conflito, com acordos específicos, de forma direta. A mediação se caracteriza pelo processo de uma reorientação das relações sociais, novas formas de cooperação, de confiança e de solidariedade. Trata-se de resolver os conflitos com a ajuda de um mediador, uma pessoa imparcial, para restabelecer o diálogo e a negociação (CHRISPINHO; DUSI, 2008; CUNHA; LEITÃO, 2016). O manejo adequado dos conflitos ocorre nos diversos ambientes que são regidos por interações sociais (MARTINS; MARQUES; GUIMARÃES, 2016).

No contexto escolar, as práticas restaurativas foram adaptadas à realidade brasileira nos projetos do Rio Grande do Sul, Brasília, São Paulo, Minas Gerais e Maranhão. Em Porto Alegre e São Caetano do Sul, as experiências foram com ações nas escolas e no âmbito da justiça infanto-juvenil, respectivamente (PINTO, 2010; ORSINI; LARA, 2013). No estado de São Paulo, as políticas públicas e programas para prevenção da violência escolar são baseados 
na mediação de conflitos (MARTINS; MARQUES; GUIMARÃES, 2016; MARTINS; ALVES, 2018).

Existem diversos tipos de conflitos no âmbito escolar, como conflitos de relacionamento, de rendimento, de identidade e de poder (CUNHA; MONTEIRO, 2016). Esses conflitos, quando negligenciados ou gerenciados de modo inadequado, tornam-se mais graves. Assim, é importante identificar a origem do conflito, posições, interesses e necessidades das partes para o seu gerenciamento adequado, com intuito de prevenir a violência (CUNHA; MONTEIRO, 2016; WAGNER, 2018).

A gestão construtiva de conflitos nas escolas pode transformar esse ambiente e as comunidades que vivenciam situações de conflito e violência em espaços de diálogos e reflexão, com resolução pacífica dessas situações. Essa transformação ocorre a partir da realização de círculos restaurativos nas escolas, com envolvimento dos gestores, professores, estudantes e famílias. Nesses espaços, são abordadas questões de disciplina ou situações de violência e apresentam-se novas possibilidades de lidar com os conflitos. Assim, as pessoas da própria comunidade escolar tornam-se facilitadoras e organizadoras das práticas restaurativas (MARTINS; MARQUES; GUIMARÃES, 2016).

Ainda na perspectiva das práticas restaurativas, uma possibilidade de intervenção em situações de violência escolar é a pesquisa-ação. Nessa estratégia, propõem-se ações envolvendo a construção de conhecimento sobre o fenômeno e a elaboração de soluções para as demandas da realidade. Autores apontam a pesquisa-ação como método efetivo para realização de pesquisas no contexto de prevenção e promoção da saúde do escolar, pois interfere diretamente nas práticas educativas, sobretudo naquelas direcionadas aos comportamentos de risco e à resolução de problemas, envolvendo pesquisadores e participantes de forma cooperativa (BRANDÃO-NETO et al., 2015; MOREIRA; VÓVIO; MICHELI, 2015; ANUNCIAÇÃO et al., 2018).

Ao considerar o pressuposto de que os profissionais da educação necessitam de formação sobre conflitos e violência escolar, assim como carecem de ações educativas baseadas no diálogo e contextualizadas para a prevenção, buscou-se responder às seguintes perguntas: "Quais as percepções dos professores sobre violência escolar?"; "Esses profissionais já vivenciaram alguma situação de violência na escola?"; "Quais são as estratégias que esses profissionais utilizam para enfrentar e prevenir a violência escolar?". O trabalho se justifica, pois reconhecer as dificuldades enfrentadas pelos profissionais da educação pode fornecer subsídios para melhoria de programas de prevenção da violência escolar e contribuir para a qualificação dos professores. 
Propõe-se, nesta tese, a capacitação de professores sobre a gestão construtiva de conflitos para a prevenção da violência escolar. Tal processo ocorre por meio da metodologia da pesquisa-ação para facilitação do diálogo e do processo de construção de conhecimento, de forma participativa. A relevância desse trabalho diz respeito à importância da promoção da cultura de paz, especialmente nas escolas, para a resolução de conflitos de forma pacífica e a partir da perspectiva dialógica. 


\section{OBJETIVOS}

\subsection{Objetivo Geral}

- Compreender as percepções dos professores de uma escola pública da rede estadual de educação básica de Ribeirão Preto/SP sobre violência escolar, e desenvolver uma ação educativa para sua prevenção.

\subsection{Objetivos específicos}

- Identificar os problemas prevalentes e os fatores que contribuem para a instalação e/ou desenvolvimento de dificuldades no meio escolar;

- Verificar o conhecimento que os professores, participantes deste estudo, têm sobre violência escolar;

- Verificar se os professores, participantes deste estudo, tiveram experiências de violência escolar como vítimas e/ou agressores;

- Verificar se existem e como são realizadas as abordagens dos agressores e das vítimas de violência escolar;

- Identificar se existem e como são realizadas as estratégias de enfrentamento utilizadas pelos professores na violência escolar;

- Desenvolver uma ação educativa para prevenção da violência escolar. 


\section{MÉTODO}

A pesquisa qualitativa permite uma visão da ciência e do conhecimento sob uma perspectiva social. O uso dessa abordagem possibilita investigar motivos, aspirações, crenças, valores, atitudes e opiniões que se expressam na interação social (TURATO, 2011). Não é pretensão dessa abordagem prever ou explicar o fenômeno, o enfoque da pesquisa qualitativa está na capacidade dos sujeitos do estudo de serem atores de sua vida e produzirem suas interpretações relacionadas à lógica social presente nos contextos, situações e experiências (OLLAIK; ZILLER, 2012).

Assim como na abordagem qualitativa, a pesquisa-ação possibilita utilização de diversas fontes de informação, diferentes técnicas para coleta dedados e para suas interpretações (CRANE; O'REGAN, 2010; STRINGER, 2007). Nessa perspectiva, a abordagem participava e cíclica da pesquisa-ação proporciona a produção do conhecimento de forma democrática e dialogada, considerando as práticas colaborativas como um recurso estratégico. Entende-se que aqueles que são afetados pela prática, são envolvidos no processo de compreensão e de mudança (CRANE; O'REGAN, 2010; LOEWENSON et al., 2014).

\subsection{Tipo de estudo}

Trata-se de uma pesquisa-ação sobre as percepções dos professores acerca da violência escolar com o propósito de desenvolver ações para sua prevenção. Nesta pesquisa, buscou-se integrar o papel educacional com o papel de investigador, aproximando os sujeitos de objetos, conhecimento da prática e observador do observado. Para melhor compreensão do leitor, será desenvolvida uma contextualização histórica sobre a pesquisa-ação.

Apesar de ser difícil indicar a origem exata da pesquisa-ação, existem autores que têm como referência desse processo o psicólogo Kurt Lewin, pois ele foi o primeiro a publicar um trabalho empregando o termo, nos anos 40, em que buscava, não somente estudar o problema in loco, mas também participar do problema (THIOLLENT, 2011; TOLEDO; GIATTI; JACOBI, 2014; MELO; MAIA FILHO; CHAVES, 2016). Contudo, foi a partir da década de 70 que o movimento da pesquisa-ação se espalhou pelo mundo, incluindo o Reino Unido, Austrália, Estados Unidos da América (EUA) e América Latina. Esse movimento diferenciouse de acordo com o contexto geográfico-cultural, temporal e com as especificidades locais e interesses, ou seja, desenvolveu-se de diferentes maneiras e com diferentes aplicações (HERR; ANDERSON, 2005; TRIPP, 2005). 
No Reino Unido, esse modelo de investigação foi orientado pela interpretação da prática, em busca das percepções dos participantes. Na Austrália, é enfatizado o caráter emancipatório, usando a reflexão crítica social. Nos EUA, esse tipo de investigação caracterizou-se como técnico, por meio de uma ciência instrumental em busca de generalizações (HERR; ANDERSON, 2005; TRIPP, 2005).

Na América Latina e no Brasil, a pesquisa-ação foi utilizada e difundida por Paulo Freire, no final da década de 60, influenciada pelos movimentos sociais e políticos libertários que marcaram aquela época. Nesse período, os conceitos de contexto e interação, propostos por Kurt Lewin, assumem novos sentidos, sob uma perspectiva prática, colaborativa e de ação social (HERR; ANDERSON, 2005; AMARAL, 2007).

Paulo Freire, quando esteve exilado no Chile, junto a educadores chilenos, iniciou diversos projetos de pesquisas temáticas sobre alfabetização e, como um processo altamente indutivo, a pesquisa tornou-se uma forma de ação social. Assim, o educador é reconhecido internacionalmente como precursor da pesquisa-ação crítica ou emancipatória na construção do conhecimento (HERR; ANDERSON, 2005; LOEWENSON et al., 2014).

No campo da saúde, vários autores destacam a influência de Paulo Freire nos movimentos de mudança da atenção e educação em saúde. Nesse contexto, o envolvimento dos sujeitos na construção do conhecimento, para o enfrentamento das dificuldades, possibilita a mudança, pois eles se reconhecem como capazes de refletir e intervir sobre sua realidade (HEIDEMANN et al., 2010; CARDOSO, 2012; BRANDÃO-NETO et al., 2015). Com base no referencial de Paulo Freire, pesquisas foram desenvolvidas a partir da metodologia de pesquisa-ação no contexto da saúde (BRANDÃO-NETO et al., 2015; ANUNCIAÇÃO et al., 2018).

A pesquisa-ação ancora-se no conhecimento pós-moderno, considerando a realidade multifacetada e a compreensão dela de modo interativo. Essa metodologia versa com base empírica, utilizando uma pluralidade de métodos nos campos de atuação social (THIOLLENT, 2011). Entende-se a realidade como subjetiva, o que torna importante a sua compreensão por meio de experiências e ações. Nesse contexto, a pesquisa-ação assemelha-se ao que muitos profissionais já fazem, pois, até certo ponto, eles planejam antes de executar a ação. Assim, há maior proximidade dos participantes com a pesquisa, tornando possível o compartilhamento de experiências para a construção social do conhecimento. Nesse processo, ocorre a transformação dos participantes pela autoconsciência da realidade (THIOLLENT, 2011). 
É importante considerar tudo o que forma a visão do mundo e a cultura dos investigadores, ou seja, os valores, as crenças e representações sociais, pois fazem parte da explicação científica (OLLAIK; ZILLER, 2012). Nessa perspectiva, é necessário analisar as trajetórias e experiências de vida dos sujeitos que, em diálogo com a ciência, são capazes de ampliar a dimensão do conhecimento, passando a existir um raciocínio crítico e reflexivo, com a finalidade de transformar a prática não reflexiva em ação democrática e emancipadora (FRANCO, 2012).

A pesquisa-ação é um tipo de investigação social, que envolve uma multiplicidade de conceitualizações teórico-filosóficas, com distintas origens, teorias, propósitos e problemas. Nesse tipo de investigação, também é possível a utilização de diversos métodos, com diferentes procedimentos e instrumentos (HERR; ANDERSON, 2005; STRINGER, 2007; THIOLLENT, 2011; OLIVEIRA; BUENO, 2016). Esse tipo de pesquisa é orientado pela ação, geralmente, participativa, diferente de outros estudos em que o pesquisador sozinho faz a teorização e as ações são deixadas para as pessoas nas situações de pesquisa. Na pesquisaação, a relação entre pesquisador e participantes ocorre a partir de um ciclo (planejamento, ação e reflexão crítica), que reside em uma combinação de rigor e flexibilidade (HERR; ANDERSON, 2005). Em síntese, essa investigação tem dois objetivos: produzir conhecimento acerca de uma determinada situação, como também promover mudança da realidade (ação).

A fundamentação teórica da pesquisa-ação se estrutura a partir do contexto e das relações e interação grupal, visando à mudança por meio de um sistema democrático de intervenção, ou seja, a ação conduz os aspectos teóricos da pesquisa (MELO; MAIA FILHO; CHAVES, 2016). Os sujeitos são envolvidos de modo participativo na investigação, de maneira autônoma, em que partilham conhecimentos e saberes que provocam reflexões e preocupações com uma dificuldade que emerge em um determinado contexto. Assim, a resolução dessas dificuldades perpassa pela mudança de comportamento dos sujeitos na comunidade (THIOLLENT, 2011; MELO; MAIA FILHO; CHAVES, 2016).

No desenvolvimento cíclico da pesquisa, o investigador inicialmente identifica as expectativas, os problemas, as características dos envolvidos e outros aspectos importantes a serem estudados ao longo do processo (CRANE; O’REGAN, 2010; THIOLLENT, 2011). O próximo passo em relação à coleta de dados pode ser ampliado ou modificado, já que o processo de reflexão é contínuo e orienta a tomada de decisões quanto à coleta, à análise e às estratégias utilizadas durante todo o percurso da pesquisa. Esse ciclo de atividades funciona como um espiral da pesquisa-ação, visando à ampliação de conhecimento sobre a questão 
original para sua solução. O ciclo básico da pesquisa-ação está ilustrado na Figura 1 (HERR; ANDERSON, 2005; CRANE; O’REGAN, 2010).

Figura 1 - Desenvolvimento cíclico desta pesquisa-ação

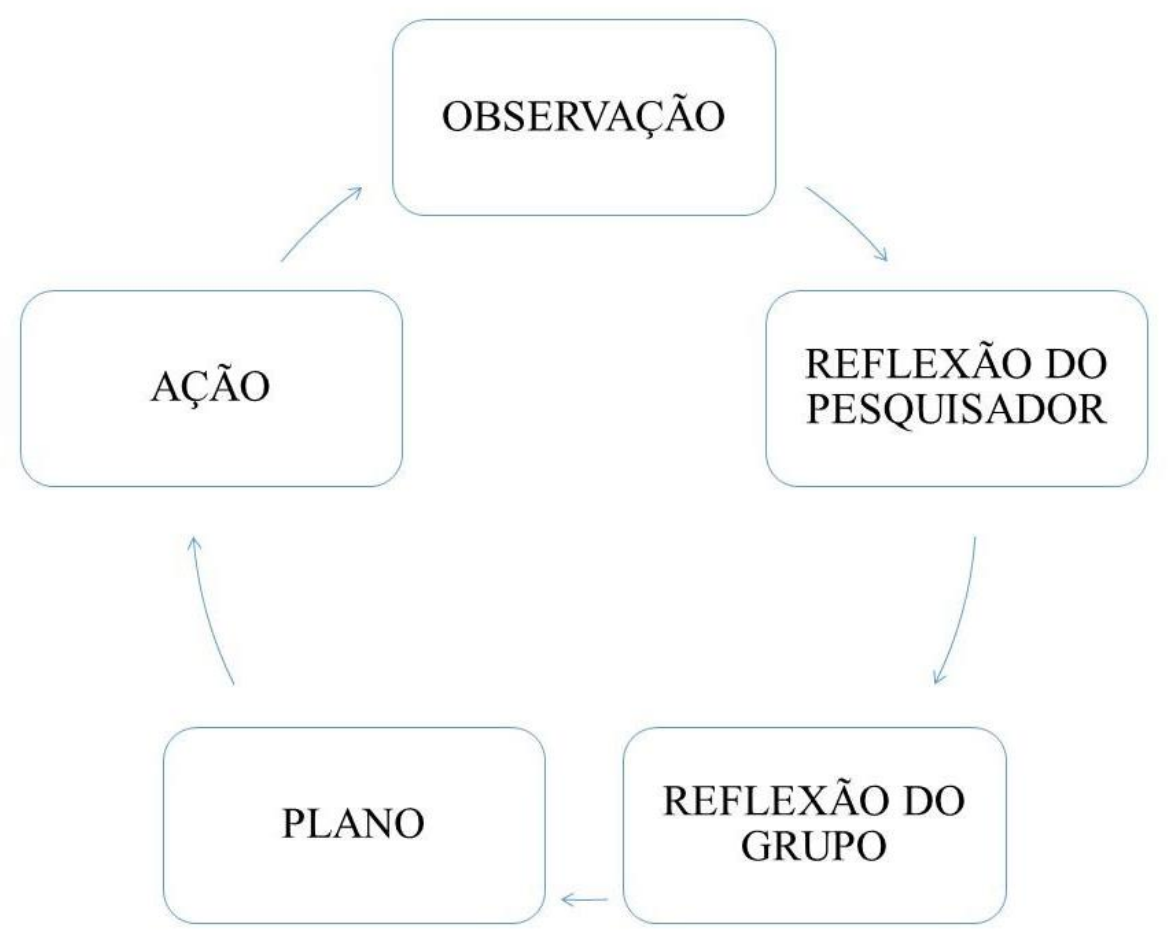

Fonte: elaborado pela autora

A eficácia desse processo ocorre com a utilização dos procedimentos cíclicos, que possibilitam avaliação contínua e refinamento das informações e interpretações. Desse modo, fornecem caminho para o aprofundamento e a compreensão por meio da colaboração e diálogo e permitem avaliar as ações realizadas transformando a prática (CRANE; O'REGAN, 2010; THIOLLENT, 2011).

Enquanto método, a pesquisa-ação propõe estreita associação com a resolução de um problema coletivo, envolvendo pesquisadores e sujeitos no processo de mudança (THIOLLENT, 2011). Sua abordagem difere dos paradigmas tradicionais de pesquisa em sua aplicabilidade, demandando do pesquisador capacidade de dar resposta à situação imediata, flexibilidade e criatividade, ao mesmo tempo em que se cumprem os requisitos de uma pesquisa científica (HERR; ANDERSON, 2005).

Além disso, mostra-se favorável, tanto para pesquisadores como para profissionais que desejem aperfeiçoar sua prática. Neste contexto, a pesquisa-ação pode ser utilizada como parte das atividades de trabalho, convidando os sujeitos a fazerem uso na sua prática, e 
aprimorarem sua ação fundamentada na pesquisa. É também considerada um instrumento para entendimento, desenvolvimento, melhoria e mudança da prática (OLIVEIRA, 2018).

A pesquisa-ação é possível a partir de um movimento contínuo de pesquisaensino/teoria-prática, que torna a produção do conhecimento participativa, emancipatória, problematizadora e dialógica. Dessa forma, conduz-se um processo cíclico de ação-reflexãoação, visando superar as dificuldades que emergem de um determinado contexto (FREIRE, 2016; HERR; ANDERSON, 2005; THIOLLENT, 2011).

A abordagem participativa é importante no desenvolvimento da pesquisa-ação, pois promove a articulação das características do contexto, das relações e dos processos de pesquisa. Desse modo, possibilita a integração entre teoria e prática, tornando a pesquisa e a ação um único processo, em que os resultados da pesquisa são aplicados a uma situação concreta (HERR; ANDERSON, 2005).

É importante o contato direto com a população em estudo, a utilização das técnicas de observação e de comunicação são fundamentais nesse processo, pois permitem obter informações acerca do ambiente e da cultura, visando identificar os temas que refletem a realidade dos mesmos. É a partir das situações problemas que serão elaborados o plano de ação educativa. Esse processo ocorre por meio de uma relação democrática, com a participação ativa de todos os envolvidos de forma dialógica e horizontal. Dessa forma, dialogando com os sujeitos, participando como iguais, constrói-se um pensamento crítico e libertador para uma sociedade com mais equidade e justiça (HEIDEMANN et al., 2010; THIOLLENT, 2011; FREIRE, 2016).

Da análise de estudos de pesquisa-ação, observa-se que essa metodologia pode ser considerada uma possibilidade de investigação e intervenção educativa em enfermagem, promovendo junto aos sujeitos a reflexão crítica, mobilização para compreensão dos problemas e construção do conhecimento coletivo para o seu enfrentamento. Essa metodologia aplicada na promoção da saúde tem se mostrado potente para a consolidação de mudanças nos contextos pesquisados, sendo possível e adequada sua utilização no contexto da investigação sobre prevenção da violência escolar (BRANDÃO-NETO et al., 2015; BRUSAMARELLO et al., 2018).

Nesse sentido, ao considerar a necessidade de reflexão e mudança da prática educativa, visando à prevenção da violência escolar e, por entender o poder transformativo da pesquisa-ação crítica/emancipatória em impulsionar a reflexão e mudança simultaneamente, optamos pela utilização dessa abordagem (LOEWENSON et al., 2014; FREIRE, 2017). 


\subsection{0 contexto da pesquisa}

\subsubsection{Local da pesquisa}

Considerando os objetivos do estudo e a abordagem metodológica da pesquisa-ação, que possibilita a mudança da prática de trabalho, o local de escolha para a pesquisa foi uma instituição da rede pública estadual de educação básica de Ribeirão Preto-SP. Por se tratar de uma instituição do âmbito estadual, existem dois documentos oficiais que estabelecem diretrizes e orientações para o funcionamento da escola, o Plano Nacional de Educação (PNE) e o Plano Estadual de Educação (PEE). Esses documentos têm como finalidade estabelecer diretrizes, metas e estratégias que atendam às demandas educacionais do município. Nos dois documentos estão determinados a criação e fortalecimento de mecanismos de acompanhamento e monitoramento das situações de discriminação, preconceitos e violências na escola, incluindo o desenvolvimento de ações destinadas à capacitação dos profissionais. Os planos (PNE e PEE) preconizam também condições adequadas para o desempenho escolar dos estudantes, em colaboração com as famílias e articulação intersetorial, incluindo profissionais da educação, saúde, assistência social, segurança pública e justiça (BRASIL, 2001; SÃO PAULO, 2016).

A instituição, campo deste estudo, fundada em 1988, está localizada no Distrito Sul de Ribeirão Preto-SP. Esse município, em 2017, teve estimativa populacional de 682.302 habitantes, destes, 94.224 estudantes matriculados no ensino fundamental e médio. Há, no município, 279 escolas que compõem a rede municipal e estadual de educação básica. Destas, 107 escolas são estaduais e oferecem Ensino Fundamental, Ensino Médio e atendem à Educação de Jovens e Adultos (EJA). No ano letivo de 2017, havia 27.276 estudantes matriculados na rede estadual de ensino fundamental e 15.394 matriculados na rede estadual de ensino médio (INSTITUTO BRASILEIRO DE GEOGRAFIA E ESTATÍSTICA, 2018).

No bairro onde a escola está inserida, além dela, há mais três escolas da rede municipal de educação infantil (2) e fundamental (1) (PREFEITURA MUNICIPAL DE RIBEIRÃO PRETO, 2018). A escola foi selecionada por conveniência, uma vez que ela é campo para a realização de atividades de ensino, pesquisa e extensão da Escola de Enfermagem de Ribeirão Preto da Universidade de São Paulo (EERP-USP). A escolha dessa escola, como campo deste estudo, ocorreu também por seu pertencimento a uma região reconhecida de grande vulnerabilidade social, ela está inserida em um complexo contexto 
socioeconômico e cultural, com histórico de violência e dificuldades na condução do processo de ensino-aprendizagem (SCHERER et al., 2011).

Essa escola, no início da investigação, em 2016, oferecia o $9^{\circ}$ ano do ensino fundamental e ensino médio, havia 680 estudantes matriculados e contava com 43 funcionários, sendo 23 professores. No final da investigação, em 2018, a escola oferecia apenas o ensino médio, havia 440 estudantes e contava com 18 professores.

\subsubsection{Participantes do estudo}

Dos 23 professores, 10 participaram do estudo, os demais se recusaram a participar por estarem envolvidos em outras atividades e por não se interessarem em participar da investigação. Os critérios de seleção dos participantes foram: ser profissional da educação da escola selecionada e trabalhar em um dos períodos, matutino, vespertino ou noturno.

No momento educativo, dois professores não participaram do plano de ação, pois foram transferidos da instituição. Dessa forma, houve alteração no número de participantes no momento da ação educativa, de 10 para 8 professores.

\subsection{Considerações éticas}

A instituição analisada foi contatada a respeito da pesquisa e o projeto apresentado à direção da escola e à dirigente da Diretoria de Ensino - Região de Ribeirão Preto-SP, para ciência e assinatura do termo de autorização para o desenvolvimento da pesquisa. Posteriormente, junto à documentação necessária, foram encaminhados e aprovados pelo Comitê de Ética em Pesquisa da Escola de Enfermagem de Ribeirão Preto da Universidade de São Paulo (EERP-USP), respeitando-se as recomendações da Resolução 466/12 (BRASIL, 2012) do Conselho Nacional de Saúde, conforme Certificado de Apresentação para Apreciação Ética - CAEE - número 47871915.6.0000.5393.

Após a aprovação do CEP da EERP-USP, em fevereiro de 2016, a direção e a coordenação da escola foram comunicadas e autorizaram a coleta de dados. Desse modo, os professores foram contatados e, após conversa com todos, foi agendada uma reunião com eles para apresentação dos objetivos e metodologia da pesquisa. No dia do encontro, as dúvidas foram esclarecidas e, posteriormente, lido e discutido o Termo de Consentimento Livre e Esclarecido (TCLE) (Apêndice A). Após a assinatura do TCLE, foram agendados os grupos focais, conforme a disponibilidade dos professores e de maneira que não interferisse no 
trabalho docente. Durante todo processo de coleta de dados, os participantes foram orientados que a qualquer momento da pesquisa eles poderiam recusar-se a participar, sem nenhum prejuízo. Os grupos foram gravados em áudio, as gravações foram transcritas e apagadas.

\subsection{Processo da pesquisa-ação}

Para operacionalização e organização da metodologia da pesquisa-ação, neste estudo, realizou-se a divisão em dois momentos: investigativo e educativo (OLIVEIRA; BUENO, 2016). Os resultados foram construídos e apresentados baseados nessa divisão.

O momento investigativo é caracterizado pela identificação das dificuldades e dos problemas enfrentados pelo grupo e sua realidade. Nesse momento, os envolvidos na situação participam da construção dos temas relevantes para o desenvolvimento da ação educativa. $\mathrm{O}$ momento investigativo é importante para o reconhecimento das principais necessidades acerca de aprendizagem sobre o fenômeno, conhecimento prévio, habilidades, assim como para o entendimento do contexto em que os participantes estão inseridos (OLIVEIRA; BUENO, 2016).

Para a identificação das dificuldades e dos problemas enfrentados pelos participantes, no contexto qualitativo, podem-se utilizar técnicas, como, por exemplo, as que foram utilizadas nesta tese: observação participante e anotação sistemática das informações, grupos focais e questionários. Tais técnicas são selecionadas de acordo com os objetivos e o contexto do estudo (OLLAIK; ZILLER, 2012). Além disso, garantem a participação e o rigor de sistematização da pesquisa-ação.

O momento educativo é caracterizado pelo desenvolvimento da ação. Esta ocorre em um movimento cíclico de ação e reflexão, considerando o diálogo e a participação ativa do sujeito, de acordo com os referenciais educacionais de Paulo Freire (OLIVEIRA; BUENO, 2016; FREIRE, 2016).

O planejamento da ação educativa é importante, pois a partir dos princípios da educação conscientizadora é elaborado um plano de ensino específico para intervenção nos temas gerados a partir do momento investigativo. A implementação do plano de ensino tem a participação ativa dos sujeitos sob a mediação do pesquisador, de forma dialógica e horizontal, na qual o debate em torno do tema promove a conscientização do grupo (FREIRE, 2016). Para tanto, podem ser utilizadas várias formas pedagógicas, dependendo das características do estudo, tais como oficinas, círculos de cultura, intervenções educativas, 
fundamentadas na participação e postura dialógica dos pressupostos educativos de Freire (OLLAIK; ZILLER, 2012).

Ressalta-se, no entanto, que apesar de fazer distinção entre os momentos, eles interligam-se e aproximam-se no movimento cíclico da pesquisa-ação, repetindo a cada momento o processo observação-reflexão-planejamento-ação (OLIVEIRA, 2018). Esse processo de investigação possibilita autoconhecimento e torna a transformação um compromisso mútuo, inerente ao processo educativo, buscando ultrapassar a dicotomia teórica entre ensinar e investigar (FREIRE, 2016).

\subsubsection{Momento investigativo}

No momento investigativo desta pesquisa-ação foram utilizadas três técnicas de coleta de dados: observação participante, grupo focal e questionário para Diagnóstico do Meio Escolar (DME). Esse processo investigativo teve início em setembro de 2015 com o objetivo conhecer o contexto do campo da pesquisa e os participantes. Nessa ocasião, estabeleceu-se o primeiro contato com os profissionais que ali atuavam e iniciou-se o compartilhamento da proximidade da vida cotidiana com os profissionais da educação, estabelecendo uma relação de confiança.

A observação participante e o registro em um diário de campo foram realizados semanalmente, com duração de duas horas, em dias e horários alternados, durante aproximadamente quatro meses, em um total aproximado de 40 horas de observação. Esses registros possibilitaram a seleção dos participantes, a negociação das ações do processo de pesquisa-ação, bem como o registro de aspectos relacionados aos acontecimentos cotidianos da escola, os profissionais participantes das situações naquele dia, quais assuntos foram abordados, as principais falas, além de impressões dos pesquisadores sobre o vivido e a situação observada. Com o intuito de compreender o fenômeno em sua profundidade, as características do ambiente e as intercorrências também foram registradas.

A observação no trabalho de campo é uma técnica direta, que consiste na relação estabelecida entre o sujeito e o objeto. A inserção do pesquisador no campo para a observação participante passa por várias etapas, incluindo o desconhecimento deste em relação ao campo e aos sujeitos, estabelecimento da credibilidade e a relação de confiança (MARQUES, 2016; CHIZZOTTI, 2018).

Nesta pesquisa, realizamos observação participante do cotidiano escolar, como horário de entrada e saída dos profissionais, inserção destes nas salas de aula, intervalos entre as 
aulas, planejamento e desenvolvimento de atividade extracurricular (gincana), participação nas reuniões de equipe, reuniões de conselhos de classe e aulas de atividade pedagógica coletiva (ATPC). Na observação participante, a posição de exterioridade do observador não existe, ele é parte integrante de sua observação. Contudo, o envolvimento consciente é necessário para a compreensão das atividades dos sujeitos e as experiências que vivenciam (MARQUES, 2016).

Para o registro constante das observações utilizamos um diário, no qual eram registradas as percepções do pesquisador antes, durante e após as atividades, considerando a participação do sujeito, a realidade observada, os temas discutidos e as dificuldades encontradas no decorrer da atividade, assim como a reflexão pessoal do pesquisador com objetivo de auxiliar na descrição do percurso das atividades (MARQUES, 2016).

Outra técnica utilizada no momento investigativo foi a de Grupo Focal, que valoriza a interação entre os participantes, de modo que eles explorem seus pontos de vista a partir de reflexões de um determinado fenômeno social. Essa é uma das técnicas que pode ser utilizada no desenvolvimento da pesquisa-ação participativa (BACKES et al., 2011; THIOLLENT, 2011).

Os encontros de grupo focal foram realizados em uma sala na própria instituição, que atendia aos requisitos para a intervenção em grupo: tamanho para comportar as cadeiras dos participantes dispostas em círculo, ambiente com privacidade, sem interferência de ruídos externos. Os três encontros aconteceram entre os meses de julho e setembro de 2016, foram conduzidos pela pesquisadora e observados por uma psicóloga especialista em violência escolar, registrados em notas, gravados em áudio com duração média de 100 minutos cada.

Para a condução dos grupos focais, um roteiro foi elaborado pelos pesquisadores e validado por três especialistas um roteiro, com questões norteadoras relacionadas ao objeto do estudo (Apêndice B). Os grupos focais foram iniciados com a apresentação dos objetivos do estudo e do grupo, de maneira que os participantes se sentissem confortáveis para falar sobre o tema proposto e então, procedia-se a apresentação dos participantes, da coordenadora e da observadora do grupo.

Também foi utilizado no momento investigativo o Questionário para Diagnóstico do Meio Escolar (DME). Esse material foi entregue aos professores, em envelopes fechados, sem identificação. O questionário é de autopreenchimento, desenvolvido e utilizado em Portugal (NUNES; CARIDADE; SANI, 2015), tem como objetivo avaliar o ambiente escolar, seu funcionamento interno, as imediações da escola, as características e o comportamento dos 
estudantes que a frequentavam, com o intuito de planejar e desenvolver ações que possam melhorar o funcionamento da escola.

O DME busca captar as percepções dos professores que observam e vivenciam os problemas na escola, bem como identificar os fatores relacionados a esses problemas (NUNES; CARIDADE; SANI, 2015). O questionário possui itens com diferentes formatos de resposta (fechada ou aberta) e o tempo de preenchimento é de 15 minutos. O DME é dividido em quatro partes: a) coleta dos dados sociodemográficos; b) informações sobre os espaços da escola e o seu entorno; c) informações sobre o funcionamento da escola; d) informações sobre as características e comportamentos dos estudantes da escola (NUNES; CARIDADE; SANI, 2015).

a) Coleta dos dados sociodemográficos, trata-se de informações referentes à caracterização dos participantes quanto às suas funções e ao tempo de serviço na escola em que foi desenvolvida a pesquisa;

b) Informações sobre os espaços da escola e o seu entorno: procura-se saber como estão os equipamentos, a estrutura física e a manutenção do ambiente escolar, assim como a segurança e o acesso ao transporte no seu entorno;

c) Informações sobre o funcionamento da escola: procura-se saber quais são as atividades extracurriculares desenvolvidas na escola, medidas disciplinares que nela são adotadas, as interações que ali se estabelecem, as relações com outras entidades e com a própria comunidade.

d) Informações sobre as características e comportamentos dos estudantes da escola: procura-se saber quais as características marcantes dos estudantes e quais os seus comportamentos.

Para utilização do questionário (DME), solicitou-se a autorização das autoras. Estas, junto à orientadora e pesquisadora deste projeto, fizeram a adaptação linguística do questionário para o português do Brasil. Foi realizado ainda o teste piloto com três profissionais de diferentes escolas da rede pública estadual de educação básica para verificar a compreensão da população de interesse deste estudo.

\subsubsection{Momento educativo}

A fim de organizar a ação educativa, de forma a transformar as dificuldades identificadas em possibilidades de aprendizado, foi criado o quarto grupo focal (BACKES et 
al., 2011). Esse grupo teve como objetivo validar as percepções dos participantes sobre os temas identificados no momento investigativo.

O quarto grupo focal também foi realizado na escola, em uma sala que atendia aos requisitos para a intervenção em grupo, em dia e horário agendados, no mês de outubro de 2018 ${ }^{3}$. Esse grupo teve duração de aproximadamente 100 minutos. Nessa ocasião, participaram do grupo oito professores, que foram convidados a falar sobre os temas identificados no momento investigativo, com intuito de identificar se ainda existiam as mesmas problemáticas naquele contexto escolar. Essa discussão ocorreu a partir dos seguintes temas: dificuldades e problemas prevalentes no ambiente escolar (comportamentos dos estudantes, relações entre a família, escola e comunidade); experiências de violência escolar (compreensões, conceitos e interpretações do fenômeno); estratégias para a prevenção da violência escolar (estratégias utilizadas pelos professores, destacando-se o sistema disciplinar punitivo).

No encontro seguinte, apresentamos aos professores uma ação educativa, que poderia auxiliá-los na transformação da realidade, utilizando os conhecimentos sobre gestão de conflitos para a prevenção da violência escolar. Essa atividade foi apoiada no referencial dialógico de Paulo Freire (FREIRE, 2016).

A fim de romper com as características mecanicistas da escola, o contexto da atividade foi organizado visando descaracterizar a sala de aula tradicional. Na ocasião, um meio círculo foi feito para que todos os participantes se olhassem, com o propósito de estabelecer relações simétricas, em que todos ensinam e aprendem, de forma coletiva. Promoveu-se a reflexão contextualizada e o debate de ideias e opiniões dos participantes. Esse debate permitiu a problematização, com fundamentação científica, sem perder de vista a tarefa de produzir conhecimento. É importante para uma educação em saúde, emancipatória, a vivência participativa com ênfase no diálogo, em que o movimento teórico-prático possibilita, de forma democrática, a produção do conhecimento a partir da experiência (FREIRE, 2016).

A relação estabelecida entre pesquisador e os participantes foi baseada na comunicação, sobretudo no diálogo, utilizando a aprendizagem centrada nos processos grupais. O processo de construção do saber em grupo representa uma leitura crítica do contexto, possibilita abertura para as dúvidas e novas inquietações. Não se refere apenas à transferência do conhecimento, mas enfatiza uma relação dialética entre sujeito e objeto, ultrapassando a visão mecanicista e ideológica no processo educativo (FREIRE, 2016).

\footnotetext{
${ }^{3} \mathrm{O}$ intervalo de tempo entre o momento investigativo e a ação educativa foi de 16 meses, em decorrência do Doutorado Sanduíche e do processo de mudança da gestão da escola campo desta pesquisa.
} 
O planejamento dessa ação educativa foi feito pela pesquisadora e validado por três especialistas da área - duas doutoras (enfermeira e psicóloga) e um mestre (psicóloga) em saúde mental com experiência na área de violência escolar - que avaliaram e deram parecer no sentido de aperfeiçoar a atividade educativa. Conforme solicitação da coordenação e dos professores, as atividades foram realizadas durante o evento de interclasse da instituição.

Para o desenvolvimento da ação educativa, foi utilizada a abordagem de ensino do Círculo de Cultura de Paulo Freire. Esse tipo de abordagem propõe a ação cultural para a libertação, que ocorre com o diálogo de maneira participativa. O círculo de cultura possibilita a construção de conhecimento, favorecendo a compreensão crítica da realidade, contrapondose à transferência de conhecimento (FREIRE, 2011). O Círculo de Cultura, também é reconhecido como uma tecnologia para o cuidado de enfermagem comunitária, que possibilita a promoção de ações de educação em saúde, reflexivas e críticas, especialmente na construção do conhecimento sobre a temática da violência escolar (BRANDÃO-NETO et al., 2015). Nesta pesquisa, o círculo de cultura foi constituído de três momentos: leitura da realidade, análise crítica da realidade e a aplicação do conhecimento (Apêndice C) (FREIRE, 2011), que foram desenvolvidos em dois encontros.

No desenvolvimento do Círculo de Cultura, durante a leitura da realidade, foram identificados os conceitos de conflito, violência escolar e as estratégias para sua prevenção, a partir das experiências dos professores. Na análise crítica da realidade, incluíram-se elementos de teorias explicativas que possibilitassem compreender melhor a complexidade da prevenção da violência escolar. Também foi promovida a autocrítica dos estilos de resolução de conflitos, de cada um dos participantes, a partir da gestão construtiva de conflitos, para a prevenção da violência escolar. Finalmente, na aplicação do conhecimento, buscamos, por meio de uma situação problema, dialogar sobre as ações que poderiam ser desenvolvidas, considerando as dificuldades enfrentadas, relacionando-as às aprendizagens construídas naquele contexto escolar.

Os dois encontros da atividade educativa tiveram duração média de duas horas cada, com a participação de oito professores. Essas atividades foram registradas por meio de gravação de áudio, fotos e anotações no diário de campo da pesquisadora.

\subsection{Organização e análise dos dados}

A análise dos dados teve como finalidade a exploração do conjunto de percepções dos professores com relação à violência escolar e sua prevenção. Essa análise ocorreu durante 
todo processo da pesquisa-ação, baseando-se no procedimento de análise temática indutiva (BRAUN; CLARKE, 2006), utilizado na interpretação de dados qualitativos por meio das seguintes etapas:

a) Organização dos dados a partir das transcrições dos grupos focais, leitura detalhada desse material, dos registros das observações, bem como das respostas dos questionários;

b) Realização de recortes do material coletado e geração de códigos iniciais;

c) Agrupamento dos temas, de acordo com a similaridade, gerando os temas potenciais;

d) Revisão dos temas, buscando comparar e identificar distinções entre eles;

e) Definição dos nomes dos temas para construção de um mapa temático. Nessa fase é fundamental identificar o que é relevante sobre o tema e o porquê, bem como a história que cada tema diz, relacionando as questões de pesquisa para assegurar que não exista sobreposição entre os temas;

f) Organização dos temas e produção do relatório final, de forma a subsidiar o momento educativo com o propósito de promover a prevenção da violência escolar. 


\section{RESULTADOS E DISCUSSÃO}

Com o desenvolvimento da pesquisa-ação, apresentam-se e discutem-se os resultados desta tese, com a finalidade de compreender as percepções e as práticas dos professores para a prevenção da violência escolar. Inicialmente, nesta pesquisa, será apresentada a caracterização dos participantes, considerando os aspectos sociodemográficos e a formação dos professores. Em seguida, a apresentação dos resultados será em duas etapas. A primeira corresponde ao conteúdo extraído do momento investigativo, e a segunda é referente ao material produzido a partir do momento educativo. Esses conteúdos apresentados foram elaborados por meio da análise temática indutiva.

\subsection{Caracterização dos participantes do estudo}

No momento investigativo, participaram do estudo 10 professores, destes, seis eram do sexo feminino e quatro do sexo masculino, com idades entre 38 e 52 anos. Em relação à área de atuação, houve, sobretudo, a participação de profissionais das áreas de ciências humanas e exatas. Já no momento educativo, participaram da ação oito professores, destes, cinco do sexo feminino e três do sexo masculino, com idades entre 39 e 52 anos. A caracterização individual dos professores quanto ao sexo, idade e área de atuação pode ser visualizada no Quadro 1.

Quadro 1 - Características sociodemográficas dos professores participantes do estudo

\begin{tabular}{|cccc|c|}
\hline Participante & Sexo & $\begin{array}{c}\text { Idade } \\
\text { (anos) }\end{array}$ & Área de Atuação & Formação Continuada \\
\hline P1 & Masculino & 52 & $\begin{array}{c}\text { Professor Mediador Escolar e } \\
\text { Comunitário (PMEC)* }\end{array}$ & $\begin{array}{c}\text { Pedagogia EAD } \\
\text { Capacitação para Professor } \\
\text { Mediador }\end{array}$ \\
\hline P2 & Feminino & 38 & História & Pedagogia EAD \\
\hline P3 & Feminino & 45 & História/Matemática & $\begin{array}{c}\text { Direitos Humanos e Estatuto } \\
\text { da Criança e do Adolescente } \\
\text { (ECA) }\end{array}$ \\
\hline P4 & Feminino & 39 & Matemática & $\begin{array}{c}\text { Pedagogia EAD } \\
\text { Informática }\end{array}$ \\
\hline P5 & Masculino & 52 & Letras & $\begin{array}{c}\text { Cursos de Capacitação da } \\
\text { Secretaria Estadual da } \\
\text { Educação }\end{array}$ \\
\hline
\end{tabular}




\begin{tabular}{|cccc|c|}
\hline P6 & Feminino & 39 & Matemática & Pedagogia EAD \\
\hline P7 & Feminino & 38 & Letras* & $\begin{array}{c}\text { Lato Sensu em Estudos } \\
\text { Literários }\end{array}$ \\
\hline P8 & Masculino & 41 & Matemática/Física & $\begin{array}{c}\text { Lato Sensu em } \\
\text { Administração Escolar }\end{array}$ \\
\hline P9 & Feminino & 52 & Letras & Currículo escolar, informática \\
\hline P10 & Masculino & 46 & Química e Matemática & $\begin{array}{c}\text { Pedagogia EAD, } \\
\text { Políticas Educacionais }\end{array}$ \\
\hline
\end{tabular}

*Não participaram do momento educativo.

Fonte: elaborado pela autora.

Os professores dessa pesquisa têm formação acadêmica e capacitações oferecidas pela Secretaria Estadual de Educação. O Professor Mediador Escolar e Comunitário (PMEC) relatou ainda ter cursado uma capacitação sobre mediação de conflitos. Dois dos professores cursaram Pós-Graduação Lato Sensu, conforme apresentado no Quadro 1. Entende-se que a formação do professor é fundamental para a superação dos problemas de convivência na escola (TOGNETTA; DAUD, 2018). No entanto, observamos que dos 10 professores, 1 possuía formação específica sobre gestão de conflitos e/ou prevenção da violência.

$\mathrm{Na}$ escola, campo do estudo, observamos que todos os professores atuavam em mais de um emprego. Os professores majoritariamente cumpriam tripla jornada de trabalho, lecionando nos três períodos: manhã, tarde e noite. Alguns lecionavam em outras instituições de ensino, pública e/ou privada, outros exerciam mais de uma atividade profissional, como artesã e instrutora de autoescola. Estudos mostram que os professores estão frequentemente expostos a um ambiente de trabalho hostil, têm elevada carga horária, atuam em maior número de escolas, com número elevado de alunos, têm menor poder de decisão e apresentam altos níveis de exaustão emocional, despersonalização e baixa realização profissional (dimensões da Síndrome de Burnout). Essa precarização das condições de trabalho expõe os professores a situações de violência (KOGA et al., 2015; MELANDA et al., 2018).

A partir da análise do Questionário DME e das narrativas dos grupos focais, elaborados no momento investigativo, foram construídas três unidades temáticas: 1) Dificuldades e problemas prevalentes no ambiente escolar; 2) Experiências de violência escolar; e 3) Estratégias para a prevenção da violência escolar. 


\subsection{Dificuldades e problemas prevalentes no ambiente escolar}

Nesta unidade temática, apresentam-se as percepções dos professores sobre os principais problemas e dificuldades identificados no meio escolar, bem como os fatores relacionados ao desenvolvimento dessas dificuldades, ou seja, como esses professores classificam o ambiente da escola, seu entorno e seu funcionamento, as características e comportamentos dos estudantes.

Os professores apontaram dificuldades no funcionamento da escola, problemas com a estrutura física, escola inserida em uma comunidade com tráfico de drogas e crimes, falta de envolvimento da família com a escola e comportamentos problemáticos dos estudantes, como desrespeito e uso de linguagem imprópria. Em relação à organização e qualidade dos espaços da escola, sete dos participantes classificaram como 'mau' e três como 'muito mau'. Eles apontaram falta de funcionários, de manutenção e limpeza (asseio), carência de equipamentos, de organização e de espaços como biblioteca, sala de aula, sala de professores, ginásio ou quadra de esportes e prática de educação física. Sabe-se que os espaços, as condições de trabalho e os problemas estruturais da escola interferem no processo de ensino-aprendizagem, pois comprometem o seu funcionamento. Além disso, a infraestrutura ruim da escola está associada a piores níveis de despersonalização entre os professores, comprometendo a saúde desses profissionais (KOGAN et al., 2015).

Quanto à estrutura da escola, observamos muros altos e com grades de proteção. Os portões de acesso, as portas das salas de aula, assim como a quadra de esportes estavam sempre trancadas com cadeados. Os banheiros utilizados pelos estudantes também dispunham de grades e permaneciam trancados durante o horário de aula. Para sua utilização era necessário solicitar a um agente de organização escolar (AOE) ou aguardar os intervalos. Havia duas salas com computadores, a de informática e uma com retroprojetor, que nos chamaram a atenção, pois possuíam duas portas, uma com grades e uma de aço, trancadas com cadeado.

Os espaços dos estudantes e dos profissionais eram separados por portas e portões que se mantinham sempre trancados, bem como o acesso dos estudantes aos espaços da escola eram monitorados pelos profissionais. Essas ações foram justificadas pelos profissionais como uma forma de controlar os comportamentos de vandalismo dos estudantes. No entanto, a literatura científica mostra que tentar controlar esses e outros comportamentos violentos a partir de medidas como vigilância sistemática dos alunos, ameaças e coações, em nada contribui para que ocorra a mudança de comportamento dos estudantes, tornando-se difícil 
implementar propostas de intervenções adequadas ao enfrentamento da violência escolar, nesse contexto (TOGNETTA; DAUD, 2018).

Em relação às características do entorno da escola, três dos participantes apontaram a presença de local de oferta de drogas como aspecto perturbador do desempenho dos estudantes. A forma como cada um destes se referiu a tal local foi:

$$
\begin{aligned}
& \text { boca de fumo }(\mathrm{P} 1) \text {; } \\
& \text { tráfico de drogas }(\mathrm{P} 2) \text {; } \\
& \text { pontos de drogas }(\mathrm{P} 5) \text {. }
\end{aligned}
$$

Estudos mostram escolas localizadas em regiões com condições sociais e econômicas de vulnerabilidade frequentemente expostas à influência dos fatores externos, como crime organizado (gangues), tráfico/consumo de drogas e vandalismo (PERES et al., 2015; VIVALTA; FONDEVILA, 2018; MOTA et al., 2018). Além disso, os fatores extra escolares podem influenciar a compreensão dos profissionais sobre o que significa violência (LEMOS et al., 2016; TOGNETTA; DAUD, 2018), o que pode contribuir para a banalização do fenômeno. Entendemos que essa situação dificulta a implementação de ações para prevenção da violência escolar, exigindo programas multidimensionais, com parcerias entre universidades e escolas, com a articulação intersetorial.

Como medidas que poderiam melhorar a escola, os professores apontaram o policiamento nas imediações, criação de espaços de lazer/esportes e aumento do número de profissionais para supervisionar a escola. Além dessas medidas, um professor descreveu outra sugestão:

Se o governo disponibilizasse material humano com condições físicas, mas não. A escola não dispõe de suporte do governo. (P4).

Identificamos que os professores apontaram medidas ligadas a fatores externos quando se trata de possibilidades para prevenir a violência escolar. Para Martins e Alves (2018), isso ocorre pois os professores apresentam dificuldades para lidar com valores sociais complexos e situações desafiadoras, sobretudo no que se refere às condições de vulnerabilidade às quais estão expostas as famílias das regiões onde as escolas se localizam.

Quanto às atividades extracurriculares desenvolvidas na escola (eventos, espaços de debate e/ou convivência), três professores classificaram como razoáveis. Em contrapartida, 
sete professores classificaram essas atividades como 'mau'. $\mathrm{Na}$ justificativa para essa classificação, os professores alegaram problemas na divulgação e na participação/motivação, tanto dos profissionais como dos alunos:

A escola faz atividades com recursos próprios e com a boa vontade de alguns. (P7);

No caso da escola pública e na atual situação, não há verbas para eventos. (P6);

Fazemos o que podemos. O governo não investe em EDUCAÇÃO. (P4).

Observamos que a carência de investimento do governo na educação afeta o desenvolvimento de atividades extracurriculares da escola. A negligência do poder público é um fenômeno histórico que acomete a educação brasileira, infringindo os direitos dos estudantes e dos profissionais, de modo que as políticas nacionais da educação contribuem para a precarização do ensino público, resultando nos baixos índices de desempenho dos estudantes e promovendo a exclusão social (LIBÂNEO, 2016). Trata-se de um cenário preocupante, visto a importância da escola e da educação pública de qualidade para a sociedade.

Os professores apontaram atividades que poderiam promover o envolvimento de todos (estudantes, professores, funcionários e pais), tais como: eventos culturais (cinema, teatro), seguido de visitas a museus e outros locais históricos (parques, jardins, monumentos e bibliotecas) e atividades esportivas. Observamos que, desses acontecimentos apontados pelos profissionais, o único desenvolvido pela escola foi o de atividades esportivas, intitulado como Gincana, que foi planejada e desenvolvida com os estudantes pelo professor de educação física, coordenador pedagógico e vice-diretora.

No entanto, estudos mostram que para a formação de uma nova cultura escolar, que promova o envolvimento dos estudantes, família e comunidade escolar, é necessário reconfigurar os modos de funcionamento da instituição e o entendimento do seu papel na sociedade contemporânea. E ressaltam que as mudanças podem ocorrer com a construção de uma cultura dialógica efetiva, promovendo o empoderamento individual e a identidade de pertencimento de grupo, assim como a responsabilidade relacional (CUNHA; MONTEIRO, 2016; LIMA; SILVA, 2017; MARTINS; ALVES, 2018; WAGNER, 2018). Entende-se que a promoção de uma cultura de paz nas instituições de ensino pode promover mudanças 
comportamentais, tornando a escola mais justa e menos violenta, contudo, é importante a formação dos professores nessa perspectiva.

O envolvimento dos pais, nas diferentes atividades escolares, foi classificado pelos professores como baixo e muito baixo. Eles apontaram como justificativas a desmotivação/desinteresse dos pais, falta de tempo e de divulgação das atividades promovidas pela escola, como relatado pelo professor:

Falta conscientização dos pais. (P6).

Observamos que a escola não promovia reuniões de forma contínua e frequente com os pais, em 4 meses de observação foi realizada uma reunião a partir da iniciativa de alguns profissionais, como coordenador e dois professores. A literatura evidencia que a interferência ou ausência da família no ambiente escolar reflete substancialmente nos resultados da instituição e na vida social de todos os envolvidos (LIMA; SILVA, 2017).

As dificuldades de envolvimento da família no processo educativo dos estudantes, devido à falta de tempo dos pais e ao não comparecimento nas atividades promovidas pela escola, também são evidenciadas nos relatos a seguir:

Você pode até fazer um café da manhã, mas os pais chegam aqui e perguntam: Que horas vai terminar? Porque eu preciso fazer duas faxinas ... Nem deram bola para café da manhã pegaram o boletim e foram embora. (P5);

Família é tudo gente. Mas não temos o respaldo da família. Porque a família é um elo desses alunos. (P1);

Fazer um trabalho com os pais? Para começar, eles não se dão essa oportunidade. Você faz uma reunião para falar do filho, ele já não vem. Imagina propor algo diferente para os pais? Você vai ficar aqui esperando. (P7).

No que se refere à prevenção da violência escolar, o envolvimento da família com a escola é fundamental, pois esse tipo de violência é atravessado por outras formas de violência interpessoal, inclusive de família, e social, que afetam a rotina escolar, o comportamento e o processo ensino-aprendizagem dos estudantes (GIORDANI; SEFFNER; DELL'AGLIO, 2017; FERRIANI et al., 2017).

Embora a tarefa dos professores seja muito complexa, entendemos que eles são protagonistas na prevenção da violência escolar. Para tanto, é necessário a formação desses profissionais para que eles aprendam a lidar com a interculturalidade, novas tecnologias, 
mudanças na estrutura familiar, valores morais e violências, que fazem parte da complexidade das sociedades contemporâneas e, consequentemente, refletem na escola tornando-a complexa (CUNHA; MONTEIRO, 2016). Portanto, os profissionais da educação precisam de formação sobre temas como participação das famílias e gestão de conflitos, considerando o tratamento holístico e sistêmico da violência escolar, e não somente com enfoque punitivo em relação aos estudantes ou professores (GIORDANI; SEFFNER; DELL'AGLIO, 2017; WAGNER, 2018).

Observamos que a escola adotava um sistema de medidas disciplinares punitivas, com suspensão de estudantes envolvidos em conflitos, convocação dos pais nessas situações, ameaças dos profissionais contra os estudantes e destes contra os professores. Além disso, percebemos o clima do ambiente escolar de insegurança, com relações hostis entre profissionais, alguns estudantes e famílias. Identificamos que os professores, diante dos problemas enfrentados em sala de aula, como discussão entre estudantes, falta de respeito e outros comportamentos vistos como inadequados, expulsavam os estudantes da sala de aula e/ou acionavam o PMEC e a direção. Situação semelhante foi encontrada em outros estudos que descrevem esse processo, como a terceirização da problemática escolar, evidenciando a necessidade de formação dos professores para gestão de conflitos (CUNHA; MONTEIRO, 2016; MARTINS; ALVES, 2018; TOGNETTA; DAUD, 2018).

Outro dado do DME é o entendimento dos professores de que promover o envolvimento dos pais/responsáveis dos estudantes poderia melhorar o sistema disciplinar da escola, associado à criação de equipes multidisciplinares e ao aumento do número de profissionais na escola. Essas percepções corroboram as informações descritas na literatura sobre prevenção da violência escolar (GIORDANI; SEFFNER; DELL'AGLIO, 2017; SILVA; ASSIS, 2018).

Embora os profissionais reconheçam a importância da equipe multidisciplinar para a prevenção da violência escolar, verificamos carência de profissionais além de professores, pedagogos e técnicos educacionais. Os participantes referiram a necessidade de atuação de psicólogo, enfermeiro e assistente social, com o propósito de auxiliá-los na gestão dos problemas e conflitos, que não são exclusivos do ambiente escolar, mas também estão relacionados ao contexto familiar dos estudantes:

Se tivesse um psicólogo da família. (P1);

Deveria ter mais profissionais envolvidos para ajudar os professores, porque tem situação que você não sabe lidar corretamente. (P4);

Não tem psicólogo, enfermeiro, assistente social. (P5); 
Um psicólogo na escola. Direto na escola... Tem hora que você tem que ser psicólogo do aluno também. (P6).

A atuação de uma equipe multidisciplinar pode favorecer o processo educativo do estudante, pois, além de promover a articulação entre os diferentes saberes no intuito de melhorar a qualidade das relações, também viabiliza ações intersetoriais (SILVA; ASSIS, 2017). Isso é possível com apoio nos conhecimentos compartilhados de outras ciências, percebendo a pluralidade de motivações que causam o conflito. Dessa forma, os profissionais podem auxiliar nas soluções para as demandas da escola, visando à prevenção da violência escolar (LIMA; SILVA, 2017).

Quanto ao comportamento dos estudantes da escola, oito dos professores classificaram como 'mau' (7) e 'muito mau' (1). As justificativas para essa classificação foram os comportamentos inadequados dos estudantes em sala de aula e recreio, falta de modelos parentais e falta de respeito pela autoridade no contexto escolar:

Em relação ao comportamento temos que levar em conta as condições sociais, econômicas e culturais que interferem. O meio com a genética também. (P5);

Muita agressividade entre eles. (P8).

Dois professores avaliaram como razoável o comportamento dos estudantes. Observamos que os professores atribuíram os comportamentos inadequados a fatores externos à escola. No entanto, a literatura descreve a relação entre medidas disciplinares da escola e comportamento dos estudantes. De acordo com Silva e Costa (2016), as escolas que adotam medidas disciplinares punitivas ou que possuem professores com comportamento agressivo tornam-se ambientes de constante tensão e conturbação, induzindo os estudantes à manifestação de comportamentos violentos.

Além disso, muitas vezes os professores não reconhecem a escola como reprodutora da violência, atribuindo os comportamentos indesejáveis dos estudantes às questões da família e aos valores morais. Nesse contexto, os profissionais da educação se aborrecem com frequência por regras convencionais (como não usar boné em sala de aula, não usar o celular ou não consumir balas ou chicletes) e, quando se deparam com os conflitos instaurados na sala de aula, terceirizam a resolução do problema, tornando-se evidente a importância da formação desses profissionais, sobretudo de professores para gestão de conflitos, compreendo 
o seu papel na construção de valores morais, como respeito, tolerância e justiça (TOGNETTA; DAUD, 2018).

Também foi identificado no DME que, na percepção dos participantes, o desrespeito entre os estudantes e a utilização de linguagem imprópria são os principais problemas de comportamento na escola, seguido do desrespeito pelos professores e funcionários de maneira generalizada, manifestação de comportamentos agressivos, perturbação do funcionamento escolar e destruição/danificação de equipamentos. Além disso, os professores perceberam o agravamento desses comportamentos nos últimos cinco anos. Estudos mostram que o clima escolar negativo está diretamente relacionado à violência, como, por exemplo, a vitimização do bullying, se comparado às escolas com clima mais positivo (KONOLD et al., 2017; SHUKLA; KONOLD; CORNELL, 2016). Nesse contexto, é necessário a elaboração de um programa de prevenção da violência escolar, com ações contextualizadas e sistematizadas, visando à promoção da cultura da paz no ambiente escolar.

\subsection{Experiências de violência escolar}

Nesta segunda unidade temática, identificaram-se diferentes compreensões, conceitos, interpretações e experiências da violência escolar, em que os professores são tanto vítimas como autores desse tipo de violência. Assim, encontrou-se, revelado por esses participantes, o que está descrito na literatura sobre violência escolar, cujo fenômeno complexo afeta o cotidiano das escolas e as relações interpessoais (ELICKER et al., 2015; KOGA et al., 2015; SILVA; ASSIS, 2018).

Como nesta pesquisa, no estudo de Mello (2018) os professores já haviam construído suas próprias percepções sobre a violência escolar, isto é, reconhecendo-a como um fenômeno concreto, amplo e complexo que se manifesta no contexto escolar de diferentes formas, embora não seja exclusiva deste. Para alguns professores, os conflitos geravam a violência na escola, manifestados por agressões verbais e físicas, conforme as falas a seguir:

Violência é o conflito de dois alunos. Às vezes um aluno pode xingar o outro e esse ser agressivo. Isso já gera uma violência. (P1);

Violência são as agressões verbais e físicas. (P6);

Violência é a forma de falar, briga, discussão, não acordo. No ensino fundamental tem mais agressão verbal, física e bullying. (P9). 
Verificamos que os professores enfrentam dificuldades na gestão de conflitos, culminando em atitudes violentas, com agressões verbais e físicas, que ocorrem devido aos sérios embates para resolução direta pelos próprios envolvidos. Essa situação está relacionada à forma tradicional da educação, que estimula unicamente a competição e obstaculiza o desenvolvimento de habilidades comunicacionais no processo educativo de formação do indivíduo, sobretudo no que se refere à cultura da paz (LIMA; SILVA, 2017).

Estudos mostram que a escola passa por transformações e apresenta dificuldades para lidar com as diferenças entre estudantes, professores, família e comunidade. Um dos aspectos relacionados a essa dificuldade está na utilização de recursos comunicativos disfuncionais, que, na maioria das vezes, promovem a legitimação da violência no ambiente escolar (FERRIANI et al., 2017; GIORDANI; SEFFNER; DELL'AGLIO, 2017; ROSA; PIERIN; MATHEUS, 2018).

Nessa pesquisa, os professores associaram o conflito exclusivamente aos aspectos negativos, geradores da violência escolar. No entanto, o conflito pode ser analisado sob a perspectiva positiva, mediante ações que combatam os comportamentos competitivos e desarmônicos, fortalecendo o aprendizado de outras formas educacionais voltadas para o diálogo e o consenso, respeitando-se as diferenças (LIMA; SILVA, 2017). Nessa perspectiva, o conflito pode promover desafios importantes para o desenvolvimento e crescimento pessoal (CUNHA; MONTEIRO, 2016).

Observamos dificuldades na comunicação entre professores, direção e estudantes, que frequentemente geravam conflitos. Pesquisas corroboram que esses embates ocorrem, de forma negativa, no ambiente escolar, pois os envolvidos não encontram outras maneiras de manifestação, que poderiam ser propiciadas pela escola por meio de ações democráticas, promovendo a participação de todos nas decisões que afetam a instituição (GIORDANI; SEFFNER; DELL'AGLIO, 2017; ROSA; PIERIN; MATHEUS, 2018). Assim, ocorre a violência escolar, com impactos negativos sobre as habilidades socioemocionais tanto dos estudantes como dos professores, afetando as relações intrapessoal e interpessoal, o processo de ensino-aprendizagem e os resultados do mercado de trabalho (TAVARES; PIETROBOM, 2016). Além disso, estudos mostram que a violência escolar pode levar ao desgaste profissional, à desmotivação para o trabalho e ao adoecimento mental do professor (KOGA et al., 2015; LIMA; COÊLHO; CEBALLOS, 2017). As dificuldades na gestão de conflitos que levam à violência escolar merecem atenção, pois considera-se a qualidade da interação entre professores e alunos e a participação dos pais na vida escolar dos filhos fatores importantes para reduzir os casos de violência escolar (TAVARES; PIETROBOM, 2016). 
Os professores compreendiam a caracterização da violência escolar como um fenômeno aos fatores socioeconômicos, à influência da mídia e à concepção de respeito dos estudantes, conforme os relatos a seguir:

Eu entendo que a violência está relacionada com o aluno, principalmente da classe baixa, do contexto público, que é a nossa vivência aqui. Eu acho que por meio do que a mídia fala, o aluno se sente vítima dessa violência. $O$ aluno vem com essa carga de violência, se sentem marginalizados pela própria cultura da pobreza e aqui dentro da sala de aula, onde todos se encontram, é que tudo isso se confronta. (P4);

O aluno que olha no fundo do seu olho e diz não ter problema ir para Fundação Casa, pois lá tem pelo menos seis refeições por dia, a mãe dele vai visitar e ele sairá um pouco dos conflitos da família. (P6);

A violência é a falta de consideração e de respeito que você tem pelo outro. Eles (estudantes) não têm a noção de respeito formada, não respeitam a hierarquia, o outro, o colega. É assim que gera a violência, porque eles são desrespeitados o tempo todo. A gente lida com essas situações o tempo todo, então a violência fica banalizada. (P10).

A violência escolar não é exclusivamente relacionada à pobreza ou à desigualdade social, no entanto, atinge principalmente estudantes com maiores desvantagens socioeconômicas, corroborando pesquisas na América Latina, inclusive no estado de São Paulo (PERES et al., 2015; McCLANAHAN; McCOY; JACOBSEN, 2015; TAVARES; PIETROBOM, 2016). Para esses professores, a violência é um fenômeno comum, no qual atos de agressão são naturais e banais, tornando-se parte do cotidiano dos estudantes e, consequentemente, da escola.

Os resultados dessa pesquisa corroboram com outros estudos, em que os professores associam a violência escolar às relações na sociedade, à comunicação e aos conflitos de poder, fruto principalmente da exclusão social. Embora os professores tenham consciência de que existe a violência escolar, eles enfrentam barreiras para o reconhecimento dessa violência em suas práticas cotidianas, relacionando-a aos fatores externos à escola (GIORDANI, SEFFNER; DELL'AGLIO, 2017; MELANDA et al., 2018).

Dois professores revelaram suas interpretações sobre violência escolar, descrevendo-a como um problema estrutural e associada ao ciclo de progressão escolar:

A violência é sistêmica. Ela se reproduz o tempo todo, por causa deste sistema que a gente vive. (P10);

A própria aprovação automática é uma violência. (P8). 
Houve ainda um professor que associou a violência escolar às políticas educacionais e ao desempenho do professor e do estudante:

O fracasso do seu aluno é o seu fracasso. Se você falhar nesse sistema, é descartado ou é a bola da vez. É uma violência o sistema do jeito que está implantado, a gente se sente coagido, sem ter o que fazer, um sentimento de impotência. E não adianta se reunir e discutir, pois, o que decidimos aqui para os nossos alunos não coincide com a política educacional do estado. Eles (alunos) perguntam: por que eu vou estudar se no final do ano todos vão passar. Então a violência não é só lá fora é também aqui adentro. (P9).

As políticas educacionais têm papel fundamental nos processos formativos e informativos desenvolvidos em sociedade, pois afetam o trabalho docente e o processo de ensino-aprendizagem, com repercussões no desenvolvimento laboral dos indivíduos (FIGUEIREDO; LEITE; FERNANDES, 2018). Para alguns professores, essas políticas ignoram a estrutura desigual e antagônica das classes sociais, promovendo a violência escolar, expressa para além de uma perspectiva mais explícita, com agressão entre os indivíduos, mas como violência simbólica. Esse tipo de violência é legitimado na escola, onde é disseminado padrão único de ensino por meio da imposição cultural da classe dominante, com gostos, crenças, posturas e valores, difundindo o caráter da meritocracia para autenticar as desigualdades (BOURDIEU; PASSERON, 2014; ROSA; PIERIN; MATHEUS, 2018).

Nesse estudo, verificamos que os professores se reconhecem como vítimas e autores da violência escolar, sobretudo no que se refere à violência simbólica. Os participantes referiram dicotomia entre as políticas educacionais e sua aplicabilidade nas práticas educativas, juntamente à desvalorização do trabalho dos professores, ao conteúdo programático, que, na maioria das vezes, não é contextualizado com a realidade da comunidade escolar, e às avaliações externas sobre o desempenho das escolas. Essas dificuldades afetam o processo de ensino-aprendizagem, geram prejuízos para saúde mental dos professores, que relataram sentimento de impotência, tristeza e baixa autoestima, refletindo na relação com os estudantes, conforme descrito a seguir.

Se o professor tivesse um salário legal, não ia precisar trabalhar em dois empregos. Então nós viemos de uma conjuntura política, social, educacional, de trabalho que quando não se atinge o resultado o professor é incompetente. E nós temos que mostrar que não damos conta do trabalho e a destruição do psicológico do aluno também nos atinge. (P3); 
Então é o famoso eu finjo que ensino, o estado finge que me paga e continuamos. Gera um combinado todos dão a mesma nota, para não criar problema. (P4);

É importante desconstruir a imagem da escola, porque ela tem um slogan muito feio: 'entra aluno e sai ladrão'. Isso mexe com a gente. Eu estou aqui há oito anos. É triste você ouvir isso. (P6);

A sensação é de impotência, porque aqui na escola estamos falando uma coisa e fora daqui estão falando ao contrário. Cria-se um mecanismo que para o professor é melhor o aluno não estar na escola, assim, terá menos trabalho. Porque, eu tenho que apresentar um resultado, mas às vezes o aluno não está nesse nível. (P7);

Se você se revolta contra o sistema, você é a bola da vez. Confirma que o professor é um fracasso, só falta, é incompetente, não deu o conteúdo. Isso me mata, porque eu sei que o professor não vai caminhar se o aluno não souber a tabuada, que é uma ferramenta de trabalho mínima, básica e fundamental que temos que usar. (P10).

A violência simbólica pode ocorrer de várias maneiras no ambiente escolar, desde a imposição de estigmas, exclusão causada pelo mau desempenho escolar, até o conteúdo ou as diretrizes curriculares que fazem parte do Projeto Político Pedagógico. Trata-se de uma violência da escola, sendo a violência simbólica um dispositivo de abuso de poder e uma prática disciplinar que causa dano social. Nesse contexto, o Estado é o detentor clássico da violência, e a escola atua como condutora de violência homogeneizadora (CHARLOT, 2002; ROSA; PIERIN; MATHEUS, 2018). Assim, a escola deixa de cumprir seu papel formal relevante e integrativo na socialização dos indivíduos, legitimando a violência simbólica.

Outras experiências como vítimas de violência escolar foram reveladas por alguns professores. Essas situações referiram-se à discriminação pelos pares, maior cobrança de resultados dos professores de áreas significativas nas avaliações externas e dificuldades de comunicação presente nas relações entre pares, situações estas geradoras de conflitos e violência, conforme relatos abaixo.

Quando nós vamos na Diretoria de Ensino eles perguntam: Qual é o seu nome? Qual a disciplina que você leciona? E qual escola? É você falar o nome da escola, que as pessoas começam a resmungar. (P6);

Os professores de matemática e português têm que dar conta, os outros professores também estão envolvidos nesse processo, mas existe uma cobrança maior em cima dessas áreas. Outro exemplo é a violência daqui eu posso falar uma coisa e o colega pode levar isso para a direção. Então eu provoco uma violência comigo mesmo. Eu preciso ter cuidado com o que vou falar, para não ser mal interpretado. Não gerar uma situação de desconforto, para eu, meus colegas e também para a própria escola. Isso é 
uma coisa da sociedade com a gente e, às vezes, reproduzimos com os alunos. (P9);

A relação entre os professores e seus pares, com dificuldades de comunicação, merece atenção, pois no meio escolar esses profissionais são confrontados, frequentemente, com a necessidade de lidar com desejos, interesses e valores distintos dos seus e podem ver-se implicados em conflitos que exigem respostas eficazes na forma como são enfrentados, sendo a comunicação assertiva fundamental nesse processo (CUNHA; MONTEIRO, 2016). No entanto, apesar dos professores saberem das situações de violência escolar, muitas vezes não encontram apoio para o seu enfrentamento, o que pode ser agravado com as dificuldades de comunicação.

Uma das estratégias de prevenção da violência escolar é a gestão de conflitos, que pode auxiliar a escola, no entanto, não pode ser utilizada isoladamente, é necessário o desenvolvimento de programas multidimensionais, com ações direcionadas para determinada sociedade ou realidade da escola (POSSATO et al., 2016). Contudo, para a efetividade da gestão de conflitos existem alguns aspectos fundamentais, incluindo a comunicação, a escuta e a compreensão da percepção dos envolvidos, assim como o contexto em que estão inseridos e a origem do conflito (McKIBBEN, 2017). No entanto, nesse estudo, verificamos que os professores apresentavam dificuldades de comunicação. Nesse contexto, entendemos que o conhecimento sobre gestão de conflitos pode qualificar os professores para a prevenção da violência escolar.

\subsection{Estratégias para a prevenção da violência escolar}

Nesta terceira unidade temática, identificaram-se as práticas utilizadas pelos professores no enfrentamento da violência escolar, ou seja, quais estratégias e ações foram realizadas com as vítimas e autores da violência. Assim, encontramos revelados por esses participantes o que está descrito na literatura sobre prevenção da violência escolar, cujas lacunas e necessidades de ações e programas de prevenção desse fenômeno evidenciam as potencialidades das ações interdisciplinares, por meio da articulação intersetorial, no enfrentamento dessa problemática. Nesse contexto, o enfermeiro tem papel importante, devido a sua atuação direta nas escolas, visando à promoção da saúde (SILVA et al., 2014).

Verificou-se que os professores consideravam importante compreender os comportamentos dos estudantes, não julgar e por meio do diálogo tentar entender a origem 
dos comportamentos agressivos, favorecendo a construção conjunta de sentidos e de relações para promoção do relacionamento harmônico em sala de aula.

Primeiramente, nós não podemos julgar o aluno. (P1);

Eu procuro entender os dois lados. Quem foi o agressor e quem foi a vítima. Então eu vou lá e converso com eles. O que está acontecendo? $O$ que aconteceu? [...] E depois com o tempo, eu fui conversando com eles, fazendo amizade, aí fica uma coisa no meio termo. (P3);

Porque muita coisa que para a gente é errado, às vezes é comum para eles. (P4);

Determinadas atitudes que você tem com alguns, não pode ter com outros. Tem aluno que não está muito legal. Precisamos levantar a autoestima deles. Converso com eles no começo do ano. Vamos tentar um bom relacionamento, porque se não vai ser desgastante para todo mundo. (P6).

Essas estratégias também foram utilizadas pelos professores para prevenção da violência escolar, corroborando pesquisas na Europa, especificamente Espanha e Portugal, e na América do Sul, sobretudo no Brasil (CUNHA; MONTEIRO, 2016; POSSATO et al., 2016; MARTINS; ALVES, 2018). Trata-se de uma alteração de paradigma cultural, contrário ao modelo vigente no que se refere a lidar com conflito. Criam-se hábitos de gestão de conflitos, nos quais se considera a diferença como um direito e não como uma ameaça (CUNHA; MONTEIRO, 2016). Nessa perspectiva, é promovido o fortalecimento dos valores democráticos, o esforço na manutenção de uma cultura de paz, a construção de um clima pacífico entre os diferentes atores sociais envolvidos na escola, o desenvolvimento do pensamento crítico, da empatia e da aceitação do outro, sendo estes elementos fundamentais para prevenção da violência escolar (WAGNER, 2018).

Por outro lado, os gestores das escolas públicas estaduais são subsidiados com informações centradas na ordem do direito, atendendo à preocupação de prepará-los para enfrentar ações de cunho judicial. Nesse sentido, os profissionais são orientados quanto à necessidade de saber ouvir (vítima e agressor), posicionar-se e encaminhar soluções coerentes às demandas locais (GOMES; MARTINS, 2016; MARTINS; ALVES, 2018).

No entanto, apesar de saberem da importância do diálogo e da escuta na gestão do conflito, sem julgar ou terceirizar o problema, muitas vezes os professores referiram-se aos comportamentos inadequados e agressivos dos estudantes como inatos, intencionais ou influência de sua família, como mostram os relatos abaixo: 
Quando eu converso com o pai e a mãe, aí consigo entender a situação, o motivo pelo qual ele está sendo agressivo. Tem coisa que o aluno faz para tumultuar mesmo, de propósito. (P1);

Mas tem hora em que você chama o pai e a mãe aqui e entende porque o filho se comporta daquele jeito. Porque o pai e a mãe são o espelho. (P4);

É índole mesmo. É a índole que faz o aluno ter essa atitude. (P5).

Achados de estudos científicos tiveram essa mesma percepção, de como a escola se exime da responsabilidade e das competências que a ela são atribuídas de fato, transferindo aos pais capacidades relacionadas ao capital cultural (ROSA; PIERIN; MATHEUS, 2018). Tal aspecto dificulta a compreensão dos professores sobre violência escolar, pois esperam que os pais sejam capazes de orientar e ajudar seus filhos nas suas tarefas, e os culpabilizam por não corresponderem às expectativas escolares (ROSA; PIERIN; MATHEUS, 2018).

Diante das dificuldades em gerenciar os comportamentos dos estudantes, os professores revelaram recorrer a medidas punitivas. Estas eram vistas, pelos profissionais, como um recurso para lidar com os comportamentos inadequados e/ou agressivos manifestados no ambiente escolar. Os participantes relataram que os estudantes também tinham a percepção de que a medida punitiva era necessária, conforme o relato abaixo:

$E$ É interessante que eles (alunos) mesmos não querem se perdoar. Chegar a um acordo. Eles têm as regras deles. Eles querem suspensão, punição. Às vezes, a própria vítima quer uma solução da direção. $O$ aluno fala assim: 'Você não vai chamar ninguém?' Aí, eles próprios vão à direção. (P2);

Elas (alunas) ficavam me cobrando: 'Professora, você não vai fazer nada?! Nossa, onde já se viu! Você deixar o aluno falar assim com você?'. Aí eu tive que dar uma bronca nelas também, porque eu tentava explicar e elas não entendiam o meu jeito. Tinha turma que quando eu me virava, eles começavam a jogar papel. Aí eu ficava brava mesmo! Dava uma bronca e eles ficavam todos quietos. (P3);

Tem casos em que a direção não se convence do que a gente fala. Porque eles (alunos) conseguem contornar a situação. Aí eu falo (para diretora): 'vai na sala, conversa com os alunos e veja o que eu falei'. Ele me chamou de cada 'nome'. Eu pedi para colocar tudo no registro de ocorrência. (P4).

Um estudo sobre a suspensão do estudante do ensino fundamental, em decorrência de atitude indisciplinar, mostrou que medidas punitivas não são eficazes na redução ou eliminação de comportamentos de indisciplina, pois produzem sentimentos negativos como nervosismo, chateação e tristeza, além da reincidência de tais comportamentos (PAULA; PAIXÃO; OLIVEIRA, 2015). Ao legitimar as medidas punitivas, os participantes tendem a 
comprometer o processo de construção conjunta das relações e, consequentemente, afetar a implementação das diversas estratégias para o enfrentamento da violência escolar, que incluem o desenvolvimento de habilidades para um relacionamento saudável, gestão de comportamentos agressivos e gerenciamento de sala de aula (COLEMAN et al., 2013; FEARNOW-KENNEY et al., 2016; HEKTNER et al., 2014; MANN et al., 2015).

Outras formas de resolução das situações de conflito e de violência escolar foram citadas pelos professores, que relataram a transferência dessas situações para o professor mediador e direção. Houve uma situação de violência na escola relacionada ao tráfico de drogas que envolveu estudantes e familiares, nesse caso foi necessário o controle social com a intervenção da polícia, como nos relatos abaixo:

O professor, em sala de aula, tenta contornar a situação. Se o professor não consegue, ele parte para mim, que sou o mediador, se eu não conseguir aí eu parto para a direção. É uma escadinha. Teve uma situação à noite, de duas meninas que brigaram, eram namoradas de traficantes. As famílias entraram no portão junto com os alunos. Começaram a jogar cadeiras um para cima do outro. Os alunos que não tinham nada a ver com a briga começaram a entrar no meio. Chamamos a polícia para resolver. (P1);

A agressividade dele é uma defesa que ele tem. Eu aprendi com o tempo o meu limite, não entrar no jogo deles. Eu tento usar todos os procedimentos, se não resolver, eu chamo o mediador, passo o caso para ele. (P2).

Assim como nesta pesquisa, nos estudos de Silva et al. (2014) e Lemos et al. (2016), os professores encontraram dificuldades em localizar as soluções necessárias para situações de violência, e transferiram a responsabilidade da intervenção para o mediador, papel centralizado em uma pessoa, ou direção da escola. Essas pesquisas corroboram as carências na formação docente e a necessidade de intervenção de equipes interdisciplinares capazes de auxiliar no trabalho de prevenção da violência escolar (SILVA et al., 2014; LEMOS et al., 2016).

Questionados se tiveram alguma formação sobre violência escolar, uma professora citou a falta de apoio e conhecimento sobre o tema:

Ninguém te dá uma orientação. Nada. O que eles [Diretoria de Ensino] falam é o seguinte: você dá aula lá meu bem, você ganha $20 \%$ de auxílio periculosidade. Dar-se por feliz. (P6).

Observamos que outros professores também referiram falta de informações sobre essa problemática. Estudos apontam problemas na formação de professores no Brasil, pois a 
violência escolar é tratada de forma superficial e ingênua, limitando-se a problemas de convivência, com ênfase no bullying, e às políticas públicas que demonstram claros limites teóricos, utilizando campanhas de conscientização e outras estratégias de terceirização do problema voltados para polícia e justiça (TAVARES; PIETROBOM, 2016; GIORDANI, SEFFNER; DELL'AGLIO, 2017; TOGNETTA. DAUD, 2018). Nesse contexto, os professores não possuem apoio para que consigam atuar de forma efetiva na resolução de conflitos e prevenção da violência escolar. Além disso, nem sempre as ações formativas oferecidas são suficientes para a redução desse tipo de violência, por não se constituírem efetivas ou por não atenderem às necessidades dos professores (SILVA et al., 2014).

Diante desse cenário, esse estudo não tem como pretensão propor uma solução simplista para a violência escolar. Contudo, ressalta-se a importância de estratégias de prevenção desse fenômeno direcionadas à formação dos professores sobre essa problemática. Entende-se que a gestão de conflitos é uma estratégia entre outras, sendo que a mediação dos conflitos na escola, isoladamente, não é a solução para lidar com as violências escolares (POSSATO et al., 2016). No entanto, assim como Possato et al. (2016), consideramos que a gestão de conflitos possibilita a valorização do diálogo no processo formativo de qualquer sujeito, sobretudo nas escolas. Nessa perspectiva, o plano de ação educativo foi elaborado a partir dos elementos fundamentais para a educação, estabelecidos por Paulo Freire (2016), que propõe a reflexão sobre a prática, as relações interpessoais, o trabalho coletivo e o saber experimental como elementos essenciais desse processo, com ênfase na gestão de conflitos para prevenção da violência escolar.

\subsection{Ação educativa: habilidades para a gestão construtiva de conflitos e prevenção da violência escolar}

Nesta unidade temática são apresentados os resultados do plano de ação desenvolvido no momento educativo. A partir da análise do Círculo de Cultura, foram construídas duas unidades temáticas: 1) Compreensão dos professores sobre os conceitos de conflitos e de violência escolar; 2) Habilidades para a gestão construtiva de conflitos e prevenção da violência escolar.

4.5.1 Compreensão dos professores sobre os conceitos de conflitos e de violência escolar 
Para desenvolver o caminhar teórico-metodológico do Círculo de Cultura, foi proposto um momento de acolhimento, em que os professores foram convidados para uma mesa de café da manhã. O objetivo dessa ação foi proporcionar um espaço de descontração aos participantes, oferecendo um ambiente na escola diferente do que eles estavam habituados, com o intuito de estabelecer relações de reciprocidade e de e de mobilizá-los no processo de construção do conhecimento. Diante da complexidade do fenômeno da violência escolar e da necessidade de conduzir uma prática educativa criativa e convidativa, bem como de promover um ambiente de harmonia e reconciliador, foi proposto um momento de acolhimento baseado nas práticas colaborativas e restaurativas. Esse tipo de ação pode ser efetiva, pois sensibiliza os professores para a instauração de novas formas de acolhimento das diferentes visões de mundo que convivem nas escolas públicas (MARTINS; MARQUES; GUIMARÃES, 2016).

Dando início ao momento de problematização para a leitura da realidade, os participantes foram mobilizados de modo a se organizarem em pequenos grupos para a produção de um cartaz. Nesse material, os professores responderam à seguinte pergunta: Qual o significado de conflito e de violência escolar para vocês? Os pesquisadores disponibilizaram cartolinas brancas e canetas hidrográficas, formando-se dois grupos com quatro professores. Cada grupo elegeu um representante para apresentação do conteúdo construído. Foram construídos os seguintes cartazes: 
Figura 2 - Cartaz sobre as percepções dos professores quanto ao significado da violência escolar, elaborado pelo grupo do Círculo de Cultura

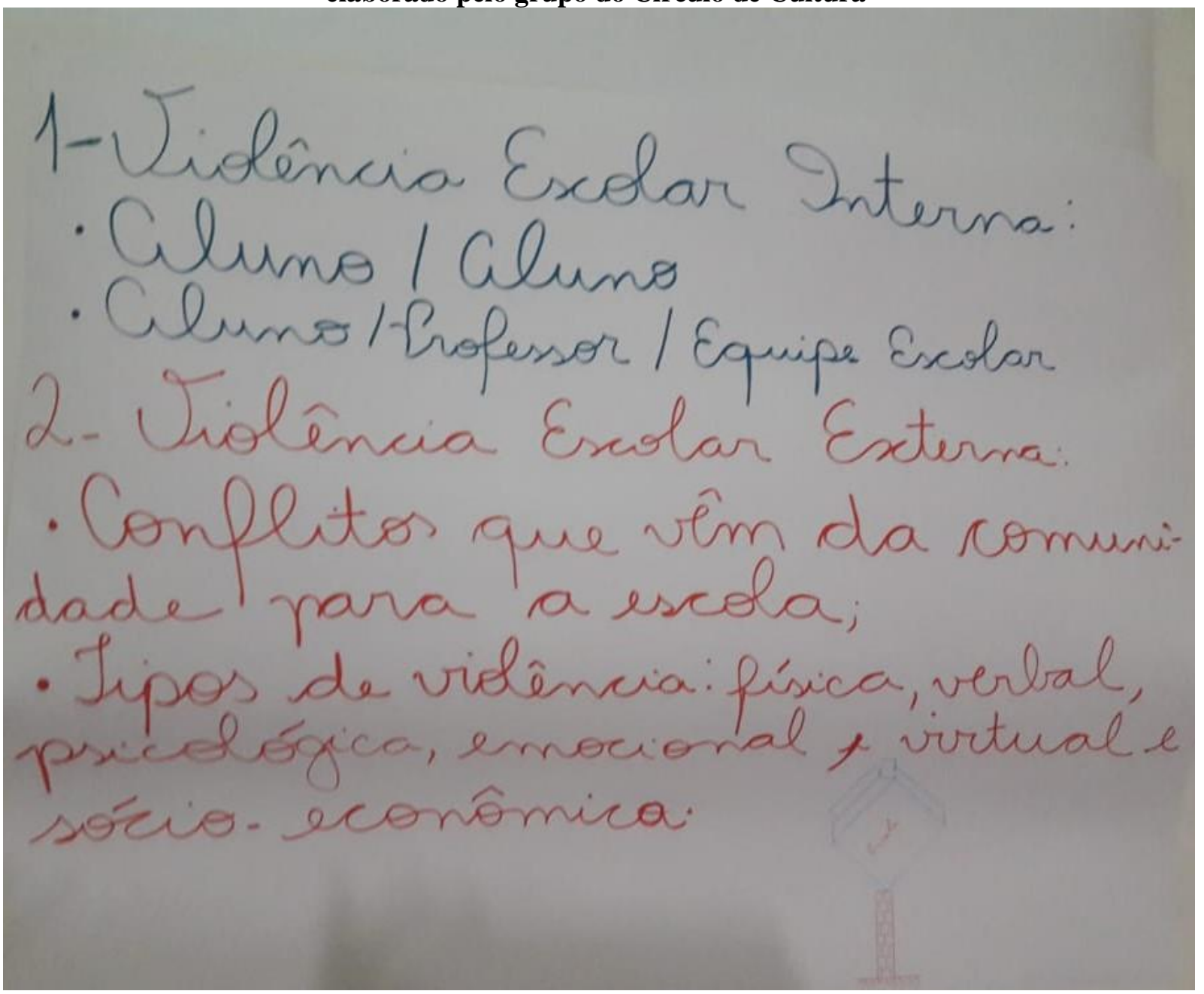

Identificou-se que os professores, ao conceituar conflito e violência escolar, descreveram a ocorrência desses fenômenos como internos e externos à escola, bem como os protagonistas envolvidos e os tipos de violência manifestados. Corroborando as percepções dos professores desta pesquisa sobre os fenômenos investigados, a literatura científica aponta a prevalência da violência escolar associada ao uso de drogas, problemas socioeconômicos, envolvimento com gangues, maior tempo dedicado a assistir TV e/ou jogando e à ideia de que quebrar as regras da escola é boa (VILALTA; FONDEVILA, 2018).

Os professores também associaram os conflitos e a violência escolar à ausência de diálogo, à falta de respeito e de princípios éticos, bem como à carência de informações sobre gestão de conflitos, conforme apresentado na Figura 2. Esses resultados evidenciam a necessidade de ações de intervenção direcionadas à qualificação dos professores.Estudos mostram a importância do diálogo no combate aos comportamentos competitivos e desarmônicos, promovendo novas formas educacionais voltadas para o consenso e respeito 
Resultados e Discussão $\mid 70$

das diferenças. Os autores destacam a contribuição da implementação da justiça restaurativa, tendo a comunidade escolar sujeitos facilitadores e organizadores de uma nova maneira de lidarem com as situações de conflito e de violência baseada no diálogo e em resoluções pacíficas dos conflitos (MARTINS; MARQUES; GUIMARÃES, 2016; LIMA; SILVA, 2017; MARTINS; ALVES; 2018).

Figura 3 - Cartaz referente às percepções dos professores sobre o significado da violência escolar, elaborado pelo segundo grupo do Círculo de Cultura

* A violquio nt escoln e'un

reflexo de violivan existarte

no cofidions do sucie dode

* Ausívia de promocáo de un diálogo com quali do de C respato aos parápios éticos.

afola de

* cantato com novas foremas de gevenciamento de conflitos.

* Biftuat oificuldade de se cotecon na posicán em que outino indiriduo ocupo en deteemine ore situaces. 
Apesar dos professores reconhecerem as características, a complexidade e a dinâmica da violência escolar, identificou-se que eles apresentaram dificuldades para diferenciar as situações de conflitos e de violência. Nesta pesquisa, os participantes compreendiam os conflitos com uma perspectiva exclusivamente negativa e geradora da violência, conforme o relato a seguir.

[...] não tem qualidade nas discussões, e as discussões geram conflitos e os conflitos geram violência. (P3);

A escola seria um ambiente onde as diversas formas de violência se transformam. (P5).

As dificuldades na identificação e na diferenciação de conflitos e de violência escolar comprometem a implementação de ações estratégicas direcionadas à gestão dessas situações de maneira construtiva e restaurativa. A literatura científica descreve que, no contexto brasileiro, os educadores são despreparados para a condução dos problemas de relacionamento entre os alunos, como, por exemplo, em situações de conflitos e de violência (TOGNETTA; DAUD, 2018), resultado semelhante foi identificado nesta pesquisa. Apesar da violência escolar ser considerada um fenômeno coletivo, em que toda a comunidade escolar participa e é corresponsável no processo, ainda existem diversas dificuldades no manejo dessas situações, que perpassam pela ausência de empoderamento individual, falta de identidade e pertencimento de grupo, bem como a omissão de responsabilidade relacional (WAGNER, 2018).

Ao buscar compreender a realidade dos professores quanto às percepções de conflitos e de estratégias para enfrentar a violência escolar, verificou-se que a manifestação desse tipo de violência está relacionada aos fatores internos e externos à escola, com repercussões na rotina escolar e nas relações estabelecidas entre professores, estudantes, direção e família. Esses profissionais também relataram dificuldades para intervir nas situações de violência que ocorriam fora do ambiente escolar, como abuso sexual, violência intrafamiliar e crimes relacionados ao tráfico de drogas. Os professores destacaram ainda a importância da implementação do trabalho multidisciplinar no enfrentamento dessas situações de violência, conforme os relatos a seguir:

A pessoa que está sofrendo violência lá fora tem outro comportamento. Qualquer coisa vai irritar ele, às vezes não é nada, é uma gota d'água ali que vai gerar uma briga na escola. (P4). 
Eu acho que certas dificuldades fogem do nosso controle. Você não está preparado para resolver um problema de, por exemplo, um menino trabalha na biqueira, tem os perrengues dele lá, quando entra dentro da escola... Como é que você vai interferir nisso, que é uma coisa maior e tal? A menina sofre abuso do padrasto, como você interfere nesse tipo de coisa? Então a gente não tem... Aí você prefere ficar de lado e não interferir diretamente nessas questões que são família, relacionamento entre eles... É mais grave do que simplesmente dar a nossa aula... Vai bem além. (P8);

A violência é interna e externa. Algumas exemplificações da violência interna são muitas vezes o maior conflito, seja entre alunos e professores, $e$ alunos com alunos de modo geral. Há uma sobrecarga e quem assume é a direção, coordenação e professores e muitas vezes a falta de identificação da personalidade do aluno, tanto em relação ao emocional, intelectual, algum problema familiar que reflete no conflito. Droga, algum desentendimento, violência em casa com pai e mãe. Já aconteceu, por exemplo, de uma professora pegar o aluno se masturbando, entre dois homens, em sala de aula. Uma professora que precisou tirar um revólver de um aluno que estava meio perturbado. São várias influências, tudo é relativo, ela soube ter autocontrole e conseguiu ir até o aluno, discreta e conseguiu tirar o revólver do aluno. Também temos relatos de que dependendo do conflito familiar... Isso reflete nas atitudes do aluno. Um aluno já levou uma faca e foi com a intenção de agredir a diretora ou algum colega. Também outras violências externas. (P5);

Eu acabo sabendo mais sobre a vida deles. É difícil. Mesmo você tomando conhecimento de como está a vida dele, dos problemas, se ele fuma, ele trafica, se ele está com problema de trabalho, se é mulher em situação de violência. E isso vem acontecendo, mas o professor não tem condições de gerenciar. Às vezes ele faz alguns encaminhamentos, mas acho que não só no estado, mas no geral está faltando profissional na escola, que o aluno sinta tanta confiança como ele tem em alguns professores, que não é em todos. (P6).

Estudos mostram que a violência intrafamiliar está diretamente relacionada com a violência escolar, sendo esses fatores associados ao desenvolvimento de problemas na saúde mental tanto dos alunos como dos profissionais (GIORDANI; DELL'AGLIO, 2016; TAVARES; PIETROBOM, 2016; LIMA; COÊLHO; DE CEBALlOS, 2017). Outro fenômeno que afeta o cotidiano escolar e fomenta a insegurança social é a violência e o tráfico de drogas, tornando o ambiente escolar agressivo e inseguro (RAMOS-JIMÉNEZ et al., 2017). Esses resultados são inquietantes visto que os professores, apesar de estarem em contato direto com os estudantes expostos aos diversos tipos de violência, não se sentem aptos para lidarem com essas situações, como identificou-se na presente pesquisa. Nesse contexto, os professores não estão preparados para manejar as ocorrências de violência que ocorrem externas à escola, como apresentado nos relatos abaixo: 
E isso vem acontecendo, mas o professor não tem condições de gerenciar. Às vezes ele faz alguns encaminhamentos, mas acho que não só no Estado, mas no geral está faltando profissional (no lugar) que ele sinta tanta confiança como ele tem em alguns professores, que não é em todos (que os alunos sentem confiança para buscar ajuda). [...] Ele chega lá e vê um aluno [...] Me deu essa ideia de fazer tal coisa, vou resolver o problema-. Falta alguém. O professor é alguém, mas nem todos dão essa abertura (aos estudantes) [...]. (P6);

Você sai do seu campo de (professor ou profissional). Eu tive uma escola que eu trabalhava, e a escola de enfermagem fazia um trabalho muito bom. Meninos de sexta série, sétima série... E aí quando as enfermeiras entravam para fazer o trabalho delas eu não participava. Por que? Porque com o tempo começou a surgir relatos que eu não queria nem ouvir, porque, como você se posiciona? Relatos do padrasto que abusava de uma menina. Ela relatou para a enfermeira. Agora você está ali, você ouve isso. A enfermeira ficou lá um tempo e foi embora. Eu não. Eu continuo lá. Um ano, dois anos, três anos, quatro anos, cinco anos. (P8).

É preciso repensar a formação continuada do professor baseada nas práticas colaborativas e restaurativas para a mudança da cultura competitiva e punitiva que está instituída nas escolas. Nesse contexto, é gerado um clima de conflitos exclusivamente negativo, que impossibilita a resolução conjunta de problemas entre as partes, tornando a escola um ambiente de injustiças e desigualdades. Para transformar essa realidade é importante estimular uma dinâmica de paz e justiça na escola, por meio da comunicação efetiva e do desenvolvimento de relacionamentos interpessoais positivos (CUNHA; MONTEIRO, 2016).

4.5.2 Habilidades para a gestão construtiva de conflitos e prevenção da violência escolar

No segundo momento do Círculo de Cultura, os professores foram convidados a debater sobre as maneiras pelas quais cada um respondia às situações para resolução de conflito. Nesse contexto, identificou-se a manifestação de comportamentos autoritários, de evitamento e de competição. O modo como esses professores reagiram às situações de conflito interferiam nos resultados alcançados, especialmente no que se refere à prevenção da violência escolar. A literatura científica descreve que é fundamental o desenvolvimento de novas formas de resolução de conflitos, especialmente baseadas em práticas colaborativas, incentivando o diálogo, o comprometimento e a cidadania. Nessa perspectiva, a gestão construtiva de conflitos é uma possibilidade que contribui para o processo de desenvolvimento pessoal e social, assim como para a prevenção da violência escolar (CORDEIRO; CUNHA, 2018). 
Identificou-se nos relatos dos participantes a ausência de recursos pessoais para lidarem com os conflitos e as situações de violência escolar. Nesse contexto, os professores manifestaram-se de modo competitivo para resolução de conflitos, usando o autoritarismo e medidas punitivas para intervenções, conforme o relato a seguir:

Emergencialmente para parar um negócio desses tem um jeito um pouco autoritário. Se tiver esses problemas, se está tumultuado, a melhor maneira no momento ali às vezes nem é o diálogo: Vamos parar com isso aqui. (P3);

Eu não acho que as coisas de psicologia podem surtir efeito, porque é instinto. $O$ único jeito de conter esse instinto é a punição. $O$ ser humano se não tiver a regra clara ali não funciona. As técnicas de psicologia funcionam, mas em determinados contextos, algumas pessoas não se controlam. Se as pessoas conseguissem se controlar não haveria a violência doméstica por exemplo. (P4);

As pessoas são movidas por interesses. Assim, a pessoa está dando a aula e se tem um problema que ela acha relevante resolver para não se estender, ela faz isso. Eu acho que o sucesso é a competição. (P6).

A resolução de conflitos a partir de comportamentos competitivos tende a atitudes assertivas, mas não cooperativas, com os envolvidos. Nessas situações, há ausência das práticas dialógicas e prevalência de autoridade, o que pode dificultar as práticas de gestão construtiva de conflitos. Esse tipo de intervenção trata-se de uma estratégia restaurativa, que promove a mudança da reação psicológica, em que os indivíduos assumem suas responsabilidades diante das situações de conflito (CUNHA; LEITÃO, 2016; CHRISPINHO; DUSI, 2008). O comportamento competitivo, muitas vezes, apresenta-se como um estilo antagônico, em que o professor visa atingir os seus próprios interesses em prejuízo dos interesses da outra pessoa. Nessas situações, há a intenção de se proteger, visando seus direitos, defendendo uma posição que acredita ser a correta ou buscando se sobressair sobre o outro (CORDEIRO; CUNHA, 2018).

Verificou-se uma postura diferente do professor quando o conflito ocorre entre pares. Diante à dificuldade de gerenciar as situações de conflito, o professor apresenta um comportamento de evitamento. Nessa circunstância, ele abstém de manifestar sua opinião com medo das consequências e reações dos seus colegas, conforme o relato abaixo.

Em uma discussão eu evito, não sou competitiva, prefiro tirar meu time de campo. Eu não vou até o fim, eu não consigo... entre os colegas eu falo, dou minha opinião, mas quando vejo que eu não sou a maioria eu considero a opinião do outro. É melhor evitar, porque muitas vezes a gente não sabe 
como lidar e vira contra você.... Você prefere evitar, para não ficar aquele clima chato. (P5).

O comportamento de evitamento ocorre quando é negligenciado o interesse de ambas as partes e pode gerar situações de conflito. Isso ocorre pela não assertividade e pela não cooperação. Nessas situações, o indivíduo tende a evitar contestações perante os problemas, tolera os eventos desconfortáveis e incômodos, adaptando-se às dificuldades e a um ambiente de trabalho difícil (CUNHA; LEITÃO, 2016; CORDEIRO; CUNHA, 2018). Percebe-se que os professores participantes desta pesquisa apresentaram comportamentos competitivo e de evitamento frente às situações de conflito, confirmando as dificuldades desses profissionais em lidar com situações de conflitos e violência escolar. A literatura científica aponta a importância da comunicação para a gestão de conflitos, pois para a resolução dessas situações é necessário assertividade e cooperação, em que os comportamentos contrários ou a comunicação ineficiente pode gerar situações de violência, além de impedir acordos que favoreçam o desenvolvimento pessoal (McKIBBEN, 2017).

Verificou-se no relato de um professor uma mudança de perspectiva, pois refere-se à tentativa de ultrapassar práticas depositárias de conhecimentos, buscando o diálogo para compreender a realidade do outro, conforme relato abaixo.

Geralmente (o aluno) não escuta. Nem o professor também. Às vezes o aluno quer um [...] nem dá muita bola. (Nesse tempo todo de experiência) no final das contas agora, eu estou escutando um pouquinho mais o que a pessoa tem a dizer, às vezes é uma coisa importante. Às vezes a gente convive com a pessoa três, quatro anos, e não conhece. (P6).

$\mathrm{Na}$ escola, é fundamental que o professor consiga fazer uma leitura do comportamento dos alunos e da diversidade que esse ambiente possui. Nesse contexto, as práticas dialógicas tornam-se necessárias para comunicações efetivas e, consequentemente, para a gestão de conflitos e prevenção da violência escolar (FREIRE, 2016; TOGNETTA; DAUD, 2018). Por outro lado, o modelo de educação, no qual o professor está inserido, baseado na prática da autoridade pedagógica, fomenta a violência simbólica e prioriza a transmissão de conteúdo, com dificuldades para trabalhar o diálogo e o desenvolvimento do pensamento críticoreflexivo. Nessas circunstâncias, o professor apresenta-se com uma postura autoritária, o que o impede de lidar com o conflito de modo construtivo e de agir de maneira a resolvê-lo, não gerando a violência (BOURDIEU; PASSERON, 2014; LEMOS et al., 2016). 
Antes de finalizar o encontro, foi realizada uma síntese com os participantes do Círculo de Cultura, revisando os principais pontos levantados por eles, relacionando-os com os conceitos que discutimos e com as ações sugeridas para resolução dos problemas apresentados. Nesse contexto, os participantes relataram que a prática da violência tem sido banalizada, como uma característica comum nas relações sociais de hoje. No entanto, ainda se percebe que os professores têm dificuldades em assumir parte da responsabilidade na ocorrência das situações de violência.

Algumas coisas não são tão complicadas como imaginamos. É simplesmente egoísmo e falta de relação humana. (P3);

Esse sentimento nosso de dificuldade de se colocar no lugar do outro serve para os alunos, entre eles, e dificuldade do aluno se colocar no lugar do professor. $O$ pessoal tem que começar a ter esse tipo de raciocínio. (P5).

Identifica-se uma falta de entendimento do papel da escola na sociedade contemporânea, em que os educadores não reconhecem a falta de identidade e de pertencimento dos estudantes e dos professores em relação ao ambiente escolar, assim como há ausência de responsabilidade relacional. Nessas circunstâncias, os professores tendem a buscar culpados para as diversas situações de conflito e violência escolar, sem reconhecer a importância das práticas colaborativas para um clima escolar positivo (CUNHA; MONTEIRO, 2016; LIMA; SILVA, 2017).

O olhar crítico sobre a realidade é uma das dimensões da abordagem de Freire (2016), que defende a educação libertadora, emancipatória, em que é respeitado o direito à flexibilidade e à corresponsabilidade no aprender e resolver dos problemas que surgem no ambiente escolar, promovendo a cidadania. Os resultados encontrados nesta pesquisa mostram uma perspectiva diferente da defendida por Freire, pois os professores assumem comportamentos autoritários e competitivos frente às situações de conflito e de violência no ambiente escolar, dificultando as relações dialógicas para construção do pensamento críticoreflexivo, bem como para mudança de uma cultura punitiva instituída na escola.

$\mathrm{Na}$ etapa final do Círculo de Cultura, foi realizada a avaliação, mediada não por um modelo de classificação, mas por uma autoavaliação quanto à vivência do processo de ensinoaprendizagem. Nesse momento, foi solicitado que o grupo fizesse uma reflexão, relatando como foi a experiência nessa pesquisa com a descoberta de novos conhecimentos a partir do tema gerador do Círculo de Cultura. Os participantes relataram a ampliação da percepção 
sobre o conflito, reconhecendo-o como possibilidade de crescimento e desenvolvimento, ultrapassando a visão exclusivamente negativa do conflito.

Conflito é situação de oposição de opiniões. (P3);

Conflitante não quer dizer que seja violento. (P5);

Eu ia dizer até mais. Sem conflito não tem aprendizagem. (P8).

Essas falas evidenciam que a ação problematizadora, proporcionada pelo Círculo de Cultura, possibilitou criar situações nas quais os professores se veem convidados a examinar criticamente suas ações cotidianas e opiniões como forma de intervenção no ambiente escolar. A literatura científica mostra o Círculo de Cultura como uma tecnologia de cuidado eficaz para trabalhar a temática da violência escolar. Esse tipo de ação possibilita o processo de conscientização e construção coletiva de conhecimento para resolução das problemáticas que surgem no ambiente escolar (BRANDÃO-NETO et al., 2015). 


\section{CONSIDERAÇÕES FINAIS}

Essa pesquisa permitiu evidenciar as percepções que os professores têm acerca da violência escolar e das estratégias para sua prevenção. A análise das falas de 10 professores que atuavam em uma escola da Rede Pública de Educação Básica permitiu identificar as dificuldades enfrentadas por eles acerca da ausência de recursos para lidarem com situações de violência escolar, falta de envolvimento dos estudantes nas atividades desenvolvidas na escola, bem como da família e da comunidade, além da manifestação de atos de violência e comportamentos agressivos. Também se percebeu a dificuldade dos professores em diferenciar as características e dinâmicas de conflito e de violência escolar. Outro achado deste estudo refere-se ao reconhecimento dos professores como vítimas e autores de violência, o que pode contribuir com o aumento de ocorrência ou com a manutenção da violência no ambiente escolar.

Entende-se que não existe um recurso simplista para a prevenção e enfrentamento da violência escolar, pois cada sociedade possui características e conflitos próprios, sendo necessária uma investigação ampla para saber qual seria a melhor atuação em determinada realidade escolar, na perspectiva de uma abordagem global com implicações na estrutura escolar. Mas é importante destacar o papel da escola no ensino/aprendizagem da transformação positiva do conflito, possibilitando a aprendizagem de formas de resolução não-violentas e, consequentemente, contribuindo para a melhoria das relações humanas. Neste estudo, percebeu-se que os professores utilizavam de medidas punitivas e comportamentos autoritários para lidarem com as situações de conflito e violência escolar.

Nesta população em particular, foi possível reconhecer que a carência de equipe interdisciplinar e a falta de envolvimento da família afetava as ações para a gestão de conflitos e prevenção da violência escolar. Depreende-se das falas dos participantes a preocupação com a falta de equipe, como enfermeiro, psicólogo, psicopedagogo e assistente social para atuarem junto à escola nas ações de prevenção da violência escolar. Nesse sentido, o enfermeiro, junto à equipe interdisciplinar, desempenha um papel importante na prevenção e enfrentamento da violência escolar ao desenvolver ações direcionadas para promoção da saúde, identificando comportamentos de risco e atuando como protagonista na articulação intersetorial. $O$ enfermeiro também tem sua atuação importante no desenvolvimento de ações do Programa Saúde na Escola, com a efetivação dessa política pública intersetorial.

A ação educativa possibilitou reconhecer a importância de um momento de reflexão entre os professores sobre as diferentes perspectivas de conflito e as maneiras de gestão para 
prevenção da violência escolar. Ressalta-se, nesse estudo, a necessidade de atividades para exercitar o diálogo, o pensamento crítico e a autoavaliação acerca dos comportamentos dos professores frente às dificuldades enfrentadas no ambiente escolar, de maneira sistemática e contínua.

Apesar da autoavaliação, realizada no momento educativo, ter proporcionado reflexão da prática dos professores e propiciado a produção do conhecimento de forma dialógica e construtiva, entende-se que não contemplou o processo de avaliação característico do método da pesquisa-ação. Para essa etapa se concretizar seria necessária a avaliação da ação desenvolvida nesta pesquisa, de modo que pudessem ser dimensionados os impactos na escola.

Quanto às limitações deste estudo, por tratar-se de uma intervenção local realizada em uma escola da rede pública de educação básica, pode não corresponder à realidade de outros locais, inclusive de escolas privadas. Nesse contexto, as políticas e a descontinuidade dos programas estaduais de educação, bem como a mudança de gestão da escola e de transferência de professores para outras instituições, dificultou o desenvolvimento da ação educativa. Outra limitação do estudo foi a participação somente dos professores, reconhecendo a importância do envolvimento de toda a comunidade escolar para a prevenção desse tipo de violência.

Para estudos futuros, sugere-se o desenvolvimento de ações educativas direcionadas às práticas restaurativas, envolvendo toda a comunidade escolar, de forma sistematizada e contínua. Sugerem-se estudos com abordagens longitudinais, pois podem auxiliar na compreensão da efetividade das ações educativas para prevenção da violência escolar ou ainda investigações que enfatizam ações de intervenções baseadas na mudança de comportamento. 


\section{REFERÊNCIAS}

ABRAMOVAY, M.; RUA, M. G. Violência nas escolas. Brasília: UNESCO, 2002.

Disponível em: <http://unesdoc.unesco.org/images/0012/001257/125791porb.pdf>. Acesso em: 06 nov. 2018.

AMARAL, V. L. A dinâmica dos grupos e o processo grupal. Natal: EDUFRN, 2007.

ANUNCIAÇÃO, L. L.; SOUZA, S. L.; CARVALHO, R. C.; AGUIAR, M. G. G.; ALVES, A. B. L. A pesquisa-ação como caminho promissor para intervir frente à violência escolar. 2018. Disponível em:

<https://proceedings.ciaiq.org/index.php/ciaiq2018/article/view/1776/1729> Acesso em 14 nov. 2018.

APEOESP (Sindicato dos Professores do Ensino Oficial do Estado de São Paulo). Pesquisa aponta que $44 \%$ dos professores já sofreram agressão verbal nas escolas estaduais de SP. São Paulo: Observatório da violência, 2017. Disponível em:

$<$ http://www.apeoesp.org.br/publicacoes/observatorio-da-violencia/pesquisa-aponta-que-44dos-professores-ja-sofreram-agressao-verbal-nas-escolas-estaduais-de-sp/> . Acesso em: 01 nov. 2018.

BACKES, D. S.; COLOMÉ, J. S.; ERDMANN, R. E.; LUNARDI, V. L. Grupo focal como técnica de coleta e análise de dados em pesquisas qualitativas. O Mundo da Saúde, v. 35, n. 4, p. 438-442, 2011. Disponível em:

<http://bvsms.saude.gov.br/bvs/artigos/grupo_focal_como_tecnica_coleta_analise_dados_pes quisa_qualitativa.pdf $>$. Acesso em 05 jul. 2018.

BECKER, K. L.; KASSOUF, A. L. Violência nas escolas públicas brasileiras: Uma análise da relação entre o comportamento agressivo dos alunos e o ambiente escolar. Nova Economia, v. 26, n. 2, p. 653-677, 2016. doi: 10.1590/0103-6351/2591.

BOURDIEU, P.; PASSERON, J. C. A reprodução: elementos para uma teoria do sistema de ensino. 7. ed. Petrópolis: Vozes, 2014.

BRADSHAW, C. P.; WAASDORP, T. E.; LEAF, P. J. Examining variation in the impact of school-wide positive behavioral interventions and Supports: findings from a randomized controlled effectiveness trial. Journal of Educational Psychology, v. 107, n. 02, p. 546-557, 2015. Disponível em: <https://eric.ed.gov/?id=EJ1061883>. Acesso em: 03 jan. 2018.

BRADSHAW, J.; GROUS, G.; REES, G.; TURNER, N. Comparing children's experiences of schools-based bullying across countries. Children and Youth Services Review, v. 80, p. 171-180, 2017. Disponível em: 〈https://doi.org/10.1016/j.childyouth.2017.06.060〉. Acesso em: 06 nov. 2018.

BRANDÃO-NETO, W.; SILVA, M. A. I.; AQUINO, J. M.; LIMA, L. S.; MONTEIRO, E. M. L. M. Violência sob o olhar de adolescentes: intervenção educativa com Círculos de Cultura. Revista Brasileira de Enfermagem, v. 68, n. 4, p. 617-625, 2015. Disponível em: <http://www.redalyc.org/articulo.oa?id=267041639009>. Acesso em: 03 set. 2018. 
BRASIL. Conselho Nacional de Saúde. Resolução n ${ }^{\circ}$ 466, de 12 de dezembro de 2012. Brasília, 2012. Disponível em:

<http://www.conselho.saude.gov.br/web_comissoes/conep/index.html. Acesso em 24 fev. 2019.

BRASIL. Lei no 13.185, de 6 de novembro de 2015. Institui o Programa de Combate à Intimidação Sistemática (Bullying). Disponível em:

<http://www.planalto.gov.br/ccivil_03/_ato2015-2018/2015/lei/113185.htm>. Acesso em: 29 ago. 2018.

BRASIL. Lei no 8.069, de 13 de julho de 1990. Dispõe sobre o Estatuto da Criança e do Adolescente e dá outras providências. Disponível em:

<http://www.planalto.gov.br/ccivil_03/LEIS/L8069.htm>. Acesso em: 12 out. 2018.

BRASIL. Ministério da Educação. Lei n ${ }^{\circ}$ 010172, de 9 de janeiro de 2001. Aprova o Plano Nacional de Educação e dá outras providências. Disponível em:

<http://portal.mec.gov.br/arquivos/pdf/L10172.pdf>. Acesso em: 05 mai. 2016.

BRASIL. Ministério da Justiça e Segurança Pública - MJSP. Lei no 13.431, de 4 de abril de 2017. Estabelece o sistema de garantia de direitos da criança e do adolescente vítima ou testemunha de violência e altera a Lei no 8.069, de 13 de julho de 1990 (Estatuto da Criança e do Adolescente). Disponível em:

<http://www.planalto.gov.br/ccivil_03/_Ato2015-2018/2017/Lei/L13431.htm>. Acesso em: 07 jul. 2017.

BRAUN, V.; CLARKE, V. Using thematic analysis in psychology. Qualitative Research in Psychology, v. 3, n. 2, p. 77-101, 2006.

BRENNER, A. K.; CARRANO, P. C. R. Os sentidos da presença dos jovens no ensino médio: representações da escola em três filmes de estudantes. Educação e Sociedade, v. 35, n. 129, p. 1223-1240, 2014. Disponível em: <http://dx.doi.org/10.1590/ES010173302014143847>. Acesso em 06 nov. 2018.

BRUSAMARELLO, T.; MAFTUM, M. A.; MANTOVANI, M. F.; ALCANTARA, C. B. Educação em saúde e pesquisa-ação: instrumentos de cuidado de enfermagem na saúde mental. Saúde, Santa Maria, v. 44, n. 2, p. 1-11, 2018. Disponível em: <http://dx.doi.org/10.5902/2236583427664>. Acesso em: 03 set. 2018.

CARDOSO, I. M. "Rodas de educação permanente" na atenção básica de saúde: analisando contribuições. Revista Saúde e Sociedade, v. 21, supl. 1, p. 18-28, 2012.

CECIL, H.; MOLNAR-MAIN, S. Olweus Bullying Prevention Program: Components Implemented by Elementary Classroom and Specialist Teachers. Journal of School Violence, v. 14, n. 4, p. 335-362, 2015. Disponível em: <https://doi.org/10.1080/15388220.2014.912956>. Acesso em: 20 nov. 2018.

CHAN, H. C. O.; WONG, D. S. W. The Overlap between School Bullying Perpetration and Victimization: Assessing the Psychological, Familial, and School Factors of Chinese Adolescents in Hong Kong. Journal of Child and Family Studies, v. 24, p. 3224-3234, 2015. Disponível em: <https://link.springer.com/article/10.1007/s10826-015-0125-7>. Acesso em: 29 out. 2018. 
CHARLOT, B. Violência na escola: como os sociólogos franceses abordam essa questão.

Sociologias - Interface, v. 4, n. 8, p. 432-443, 2002. Disponível em

<http://www.scielo.br/pdf/soc/n8/n8a16.pdf>. Acesso em: 25 ago. 2016.

CHIZZOTTI, A. Pesquisa em ciências humanas e sociais. 12 ed. São Paulo: Cortez, 2018.

CHRISPINHO, A.; DUSI, M. L.H. M. Uma proposta de modelagem de política pública para a redução da violência escolar e promoção da Cultura da Paz. Ensaio: Avaliação e Políticas Públicas em Educação, v. 16, n. 61, p. 597-624, 2008. Disponível em:

<http://dx.doi.org/10.1590/S0104-40362008000400007>. Acesso em: 22 nov. 2018.

CONSELHO NACIONAL DE JUSTIÇA. Justiça nas escolas. 2010. Disponível em: $<$ http://www.cnj.jus.br/gestao-e-planejamento/262-acoes-e-programas/programas-de-a-az/justica-nas-escolas/13055-justica-nas-escolas>. Acesso em: 23 set. 2018.

CORDEIRO, J.; CUNHA, P. Gestão de conflitos, comportamentos de comprometimento e de cidadania organizacional em contexto educativo: contributos para a formulação de um modelo conceitual. European Journal of Applied Business Management, v. 4, n. 3, 2018, p. 46-66, 2018. Disponível em:

<https://comum.rcaap.pt/bitstream/10400.26/24558/1/Artigo\%20Revista\%20EJABM\%20201 $8 \% 20-\% 20 \mathrm{GC} \% 2 \mathrm{c} \% 20 \mathrm{CCO} \% 20 \mathrm{e} \% 20 \mathrm{CO} \% 20$ modelo\%20concetual.pdf $>$. Acesso em: 14 nov. 2018.

COSTA, P.; PINTO, J.; PEREIRA, H.; PEREIRA, B. Bullying Genérico e Homofóbico no Contexto Escolar. Psychology, Community \& Health, v. 4, n 3, p. 145-155, 2015.

Disponível em: <https://www.researchgate.net/publication/284771245>. Acesso em: 31 out. 2018.

CRANE, P.; O'REGAN, M. PAR: using participatory action research to improve early intervention. Canberra: Department of Families, Housing, Community Services and Indigenous Affairs Australian Government, 2010. Disponível em: <https://www.dss.gov.au/sites/default/files/documents/05_2012/reconnect_0.pdf>. Acesso em: 08 jul. 2016.

CROOKS, C. V., CHIODO, D., ZWARYCH, S., HUGHES, R., WOLFE, D. A. Predicting Implementation Success of an Evidence-based Program to Promote Healthy Relationships among Students Two to Eight Years After Teacher Training. Canadian Journal of Community Mental Health, v. 32, n. 1, 2013.

CUNHA, P.; LEITÃO, S. Manual de gestão construtiva de conflitos. 3 ed. Porto, Portugal: Edições Universidade Fernando Pessoa, 2016.

CUNHA, P.; MONTEIRO, A. P. Uma reflexão sobre a mediação escolar. Ciências \& Cognição, v. 21, n. 1, p. 112-123, 2016. Disponível em: 〈http://www.cienciasecognicao.org〉. Acesso em: 14 nov. 2018.

CUNHA, P.; MONTEIRO, A. P.; LOURENÇO, A. A.; MOREIRA, R. B. Conflitos em contexto de saúde: um instrumento de avaliação de estilos de gestão de conflito. Revista Portuguesa de Enfermagem de Saúde Mental, n. 20, p. 09-18, 2018. doi: 10.19131/rpesm.0221 
DEBARBIEUX, E.; BLAYA, C. (Col.). Violência nas Escolas e Políticas Públicas. Brasília: UNESCO, 2002. Disponível em:

<http://unesdoc.unesco.org/images/0012/001287/128720por.pdf>. Acesso em: 19 nov. 2018.

ELICKER, E.; PALAZZO, L. S.; AERTS, D. R. G. C.; CÂMARA, S. Uso de álcool, tabaco e outras drogas por adolescentes escolares de Porto Velho-RO, Brasil. Epidemiologia e

Serviços de Saúde, v. 24, n. 3, p. 399-410, 2015. Disponível em:

<https://www.scielosp.org/pdf/ress/2015.v24n3/399-410/pt>. Acesso em: 01 nov. 2018.

FEARNOW-KENNEY, M., HILL, P., GORE, N. Child and parent voices on a communitybased prevention program (FAST). The School Community Journal, v. 26, n. 1, p. 223-238, 2016.

FERRIANI, M. G. C.; CARLOS, D. M.; OLIVEIRA, A. J.; ESTEVES, M. R.; MARTINS, J.E. Vínculos institucionais para o enfrentamento da violência escolar: um estudo exploratório. Esc Anna Nery, v. 21, n. 4, 2017. doi: 10.1590/2177-9465-EAN-2016-0347.

FIGUEIREDO, C.; LEITE, C.; FERNANDES, P. Uma tipologia para a compreensão da avaliação de escola. Revista Brasileira de Educação, v. 23, p. 1-25, 2018. doi: 10.1590/s1413-24782018230018.

FILLIS, M. M. A.; DE ANDRADE, S. M.; GONZÁLEZ, A. D.; MELANDA, F. N.; MESAS, A. E. Frequência de problemas vocais autorreferidos e fatores ocupacionais associados em professores da educação básica de Londrina, Paraná, Brasil. Cadernos de Saúde Pública, v. 32, n. 1, p. 1-10, 2016. Disponível em:

<https://www.scielosp.org/pdf/csp/2016.v32n1/e00026015/pt>. Acesso em: 06 nov. 2018.

FINKELHOR, D.; VANDERMINDEN, J.; TURNER, H.; SHATTUCK, A.; HAMBY, S. AtSchool Victimization and Violence Exposure Assessed in a National Household Survey of Children and Youth. Journal of School Violence, v. 15, n. 1, p. 67-90, 2016. Disponível em: <https://doi.org/10.1080/15388220.2014.952816. Acesso em; 30 out. 2018.

FRANCO, M. A. S. Práticas colaborativas na escola: as possibilidades da pesquisa-ação pedagógica. XVI ENDIPE - Encontro Nacional de Didática e Práticas de Ensino, 2012, UNICAMP - Campinas. Anais... Campinas: Junqueira \& Marin Editores, 2012. Livro, 3, p. 000268. Disponível em:

<http://www.infoteca.inf.br/endipe/smarty/templates/arquivos_template/upload_arquivos/acer vo/docs/0093s.pdf>. Acesso em: 08 jun. 2016.

FREIRE, P. Pedagogia da tolerância. 5 ed. São Paulo: Editora Paz e Terra, 2016.

FREIRE, P. Pedagogia do oprimido. 50. ed. São Paulo: Paz e Terra, 2011.

FREIRE, P. Política e educação. 3 ed. São Paulo: Editora Paz e Terra, 2017.

GARBIN, C. A. S.; GATTO, R. C. J.; GARBIN, A. J. I. Prevalência de bullying em uma amostra representativa de adolescentes brasileiros. Archives of Health Investigation, v. 5, n. 5, p. 256-261, 2016. Disponível em: <http://dx.doi.org/10.21270/archi.v5i5.1701〉. Acesso em: 1 nov. 2018.

GARCÍA-GARCÍA, J.; ORTEGA, E.; DE LA FUENTE, L.; ZALDÍVAR, F.; GIL-FENOY, M. J. Systematic Review of the Prevalence of School Violence in Spain. Procedia - Social 
and Behavioral Sciences, 237, p. 125-129, 2017. Disponível em: <https://www.sciencedirect.com/science/article/pii/S1877042817300526>. Acesso em: 31 out. 2018 .

GIORDANI, J. P.; DELL'AGLIO, D. D. Violência escolar: associação com violência intrafamiliar, satisfação de vida e sintomas internalizantes. Boletim Academia Paulista de Psicologia, v. 36, n. 91, p. 340-356, 2016. Disponível em:

<http://pepsic.bvsalud.org/pdf/bapp/v36n91/v36n91a07.pdf>. Acesso em: 20 nov. 2018.

GIORDANI, J. P.; SEFFNER, F.; DELL'AGLIO, D. D. Violência escolar: percepções de alunos e professores de uma escola pública. Psicologia Escolar e Educacional, v. 21, n.1, p. 103-111, jan./abr. 2017. doi: 10.1590/2175-3539/2017/02111092.

GONÇALVES; L. A. O.; SPOSITO, M. P. Iniciativas públicas de redução da violência escolar no Brasil. Cadernos de Pesquisa, n. 115, p. 101-138, 2002. Disponível em: <http://dx.doi.org/10.1590/S0100-15742002000100004>. Acesso em: 22 nov. 2018.

HA THI HAI LE, M. P. D.; CAMPBELL, M. A.; GATTON, M. L.; NGUYEN, H. T.; TRAN, N. T. Temporal patterns and predictors of bullying roles among adolescents in Vietnam: a school-based cohort study. Psychology, Health \& Medicine, v. 22, n. S1, 107-121, 2017. Disponível em: <http://dx.doi.org/10.1080/13548506.2016.1271953>. Acesso em 29 out. 2018.

HEIDEMANN, I. B. S., BOEHS, A. E.; WOSNY, A. M.; STULP, K. P. Incorporação teóricoconceitual e metodológica do educador Paulo Freire na pesquisa. Revista Brasileira de Enfermagem, v. 63, n. 3, p. 416-20, 2010. Disponível em: <http://www.scielo.br/pdf/reben/v63n3/a11v63n3.pdf>. Acesso em: 22 nov. 2018.

HELLFELDT, K.; GILL, P. E.; JOHANSSON, B. Longitudinal Analysis of Links Between bullying Victimization and Psychosomatic Maladjustment in Swedish Schoolchildren.

Journal of School Violence, v. 17, n. 1, p. 86-98, 2018. Disponível em: <https://onlinelibrary.wiley.com/doi/epdf/10.1111/josh.12513>. Acesso em: 31 out. 2018.

HERR, K.; ANDERSON, G. L. The action research dissertation: a guide for students and faculty. California: Saga, 2005.

HUTCHINGS, J.; MARTIN-FORBES, P.; DALEY, D.; WILLIAMS, M. E. A randomized controlled trial of the impact of a teacher classroom management program on the classroom behavior of children with and without behavior problems. Journal of School Psychology, 51, p. 571-585, 2013.

INSTITUTO BRASILEIRO DE GEOGRAFIA E ESTATÍSTICA: banco de dados do município de Ribeirão Preto. Disponível em: <https://cidades.ibge.gov.br/brasil/sp/ribeiraopreto/panorama. Acesso em 05 jul. 2018.

KOGA, G. K. C.; MELANDA, F. N.; DOS SANTOS, H. G.; SANT’ANNA, F. L.; GONZÁLEZ, A. D.; MESAS, A. E.; DE ANDRADE, S. M. Fatores associados a piores níveis na escala de Burnout em professores da educação básica. Cadernos de Saúde Coletiva, v. 23, n. 3, p. 268-275, 2015. Disponível em: $<$ http://www.scielo.br/scielo.php?script=sci_arttext\&pid=S1414-462X2015000300268>. Acesso em: 1 nov. 2018. 
KONOLD, T.; CORNELL, D.; SHUKLA, K.; HUANG, F. Racial/Ethnic Differences in Perceptions of School Climate and Its Association with Student Engagement and Peer Aggression. J Youth Adolescence, v. 46, p. 1289-1303, 2017. doi: 10.1007/s10964-0160576-1.

KRUG, E. G.; LINDA, L.; DAHLBERG, L. L; MERCY JA, Z. W. I. A. B.; LOZANO R. Relatório mundial sobre violência e saúde. Geneva: World Health Organization; 2002. Disponível em: <URL: http://www.opas.org.br/wp-content/uploads/2015/09/relatoriomundial-violencia-saude.pdf $>$. Acesso em: 20 nov. 2015.

LEMOS, V. C.; MENDES, V. R.; NOVAES, L. C.; BRAVO, M. H. Livros de Ocorrência: violência e indisciplina em escolas de território vulnerável. Arquivos Analíticos de Políticas Educativas, v. 24, p. 1-25, 2016. Disponível em: <http://www.redalyc.org/pdf/2750/275043450112.pdf>. Acesso em: 20 nov. 2018.

LIBÂNEO, J. C. Políticas educacionais no Brasil: desfiguramento da escola e do conhecimento escolar. Cadernos de Pesquisa, v. 46, n. 159, p. 38-62, jan./mar. 2016.

LIMA, A. F. T.; COÊLHO, V. M. S.; DE CEBALLOS, A. G. C. Violência na escola e transtornos mentais comuns em professores. Revista Portuguesa de Enfermagem de Saúde Mental, n. 18, p. 31-36, 2017. Disponível em: 〈http://dx.doi.org/10.19131/rpesm.0189>. Acesso em: 1 nov. 2018.

LIMA, M. H. C.; SILVA, L.A.M.G. Mediação Interdisciplinar e sua aplicação no ambiente escolar: construção da dignidade humana e disseminação da cultura da paz. Revista Cidadania e Acesso à Justiça, v. 3, n. 2, p. 96 - 116, 2017. Disponível em: <http://www.indexlaw.org/index.php/acessoajustica/article/view/2566>. Acesso em: 22 nov. 2018.

LOEWENSON, R.; LAURELL; A. C.; HOGSTEDT, C.; D'AMBRUOSO, L.; SHROFF, Z. Participatory action research in health systems: a methods reader. Canadá: TARSC, AHPSR, WHO, IDRC, 2014.

MACAIA, A. A. S.; FISCHER, F. M. Retorno ao trabalho de professores após afastamentos por transtornos mentais. Saúde e Sociedade, v. 24, n. 3, p. 841-852, 2015. Disponível em: <https://www.scielosp.org/pdf/sausoc/2015.v24n3/841-852/pt>. Acesso em: 06 nov. 2018.

MARCOLINO, E. C.; CAVALCANTI, A. L.; PADILHA, W. W. N.; DE MIRANDA, F. A. N.; CLEMENTINO, F. S. Bullying: prevalência e fatores associados à vitimização e à agressão no cotidiano escolar. Texto Contexto Enfermagem, v. 27, n. 1, p. 1-10, 2018. Disponível em: <http://dx.doi.org/10.1590/0104-07072018005500016. Acesso em 01 nov. 2018.

MARQUES, J. P. A “observação participante” na pesquisa de campo em Educação. Educação em Foco, v. 19, n. 28, p. 263-284, 2016.

MARTINS, A. M.; ALVES, M. G. Situações de conflito e violência em escolas públicas: aproximações entre Brasil e Portugal. Revista de Sociología de la Educación (RASE), v. 11, n. 1, p. 153-166, 2018. Disponível em: 〈http://dx.doi.org/10.7203/RASE.11.1.10734>. Acesso em: 22 nov. 2018. 
MARTINS, P. F. M.; MARQUES, J. F.; GUIMARÃES, H. M. Educação e justiça restaurativa: os desafios na resolução de conflitos no ambiente escolar. Revista esmat, v. 8, n. 11, p. 11-28, fev. 2016. Disponível em:

<http://esmat.tjto.jus.br/publicacoes/index.php/revista_esmat/article/view/129/133>. Acesso em: 05 dez. 2018.

McCLANAHAN, M.; McCOY, S. M.; JACOBSEN, K. H. Forms of bullying reported by middle-school students in Latin America and the Caribbean. Advances in School Mental Health Promotion, v. 8, n. 1, p. 42-54, 2015. Disponível em:

<http://dx.doi.org/10.1080/1754730X.2014.978118>. Acesso em: 01 nov. 2018.

McKIBBEN, L. Conflict management: importance and implications. British Journal of Nursing, v. 26, n. 2, p. 100-103, 2017. Disponível em:

<https://doi.org/10.12968/bjon.2017.26.2.100>. Acesso em: 05 mai. 2018.

MELANDA, F. N.; DOS SANTOS, H. G.; SALVAGIONI, D. A. J.; MESAS, A. E.; GONZÁLEZ, A. D.; DE ANDRADE, S. M. Violência física contra professores no espaço escolar: análise por modelos de equações estruturais. Cadernos de Saúde Pública, v. 34, n. 5, p. 1-12-2018. Disponível em: <http://www.scielo.br/pdf/csp/v34n5/1678-4464-csp-34-05e00079017.pdf>. Acesso em: 1 nov. 2018.

MELLO, F. C. M.; MALTA, D. C.; DO PRADO, R. R.; FARIAS, M. S.; ALENCASTRO, L. C. S.; SILVA, M. A. I. Bullying e fatores associados em adolescentes da Região Sudeste segundo a Pesquisa Nacional de Saúde do Escolar. Revista Brasileira de Epidemiologia, v. 19, n. 04, p. 866-877, 2016. Disponível em: <https://doi.org/10.1590/19805497201600040015>. Acesso em: 1 nov. 2018.

MELO, A. S.E.; MAIA FILHO, O. N.; CHAVESI, H. V. Lewin e a pesquisa-ação: gênese, aplicação e finalidade. Fractal: Revista de Psicologia, v. 28, n. 1, p. 153-159, 2016. Disponível em: <http://dx.doi.org/10.1590/1984-0292/1162>. Acesso em: 10 set. 2018.

MOREIRA, A.; VÓVIO, C. L.; MICHELI, D. Prevenção ao consumo abusivo de drogas na escola: desafios e possibilidades para a atuação do educador. Educação e Pesquisa, v. 41, n. 1, p. 119-135, 2015. Disponível em: 〈http://dx.doi.org/10.1590/S1517-97022015011670〉. Acesso em:03 set. 2018.

MOREIRA, J. O.; SALUM, M. J. G.; OLIVEIRA, R. T. Estatuto da Criança e do Adolescente: refletindo sobre sujeitos, direitos e responsabilidades. Brasília: Conselho Federal de Psicologia, 2016. Disponível em:

<https://www.researchgate.net/profile/Paula_Melgaco2/publication/312232119_O_Plano_Ind ividual_de_AtendimentoPIA_nas_medidas_socioeducativas_para_o_adolescente_com_o_ado lescente_ou_sobre_o_adolescente/links/5877a7f508ae8fce492fcb1b/O-Plano-Individual-deAtendimentoPIA-nas-medidas-socioeducativas-para-o-adolescente-com-o-adolescente-ousobre-o-adolescente.pdf\#page=89> . Acesso em: 10 set. 2018.

MOTA, R. S.; GOMES, N. P.; CAMPOS, L. M.; CORDEIRO, K. C. C; SOUZA, C. N. P.; DE CAMARGO, C. L. Adolescentes escolares: associação entre vivência de Bullying e consumo de álcool/drogas. Texto Contexto Enfermagem, v. 27, n. 3, p. 1-10, 2018. Disponível em: <http://dx.doi.org/10.1590/0104-07072018003650017>. Acesso em: 01 nov. 2018. 
NAPOLETANO, A. Neighborhood crime, relative deprivation, and school violence in Canadian adolescents. 2014. 65 f. Dissertação (Mestrado em Psiquiatria) -Department of Psychiatry, McGill University, Montreal, 2014. Disponível em:

<http://digitool.library.mcgill.ca/webclient/StreamGate?folder_id=0\&dvs=1541095956973 1 1>. Acesso em: 01 nov. 2018.

NESELLO, F.; SANT’ANNA, F. L.; DOS SANTOS, H. G.; DE ANDRADE, S. M.; MESAS, A. E.; GONZÁLEZ, A. D. Características da violência escolar no Brasil: revisão sistemática de estudos quantitativos. Revista Brasileira de Saúde Materno Infantil, v. 14, n. 2, p. 119136, 2014. Disponível em: <http://dx.doi.org/10.1590/S1519-38292014000200002〉. Acesso em: 06 nov. 2018.

NETRAWATI; FURQON; SYAMSU YUSUF; NANDANG; RUSMANA. Solving Adolescent Verbal Aggressions through Transactional Analysis Counseling Approach. Journal of Education and Practice, v. 7, n. 8, 2016.

NUNES, L. M.; CARIDADE, S.; SANI, A. I. Avaliação do meio escolar: um estudo exploratório. Revista Lusófona de Educação, v. 30, p. 141-158, 2015. Disponível em: <http://revistas.ulusofona.pt/index.php/rleducacao/article/view/5133>. Acesso em: 06 nov. 2016.

OLIVEIRA, R. G. Docência Universitária na Saúde: limites e possibilidades para uma prática inovadora. 2018. 109 f. Tese (Doutorado em Ciências) - Escola de Enfermagem de Ribeirão Preto, Universidade de São Paulo, Ribeirão Preto, 2018.

OLIVEIRA, R. G.; BUENO, S. M. V. Processos educativos transformadores no contexto da saúde: uma proposta metodológica para pesquisa ação. Atas - Investigação Qualitativa em Saúde, v. 2, p. 674-78, 2016. Disponível em:

<https://proceedings.ciaiq.org/index.php/ciaiq2016/article/view/809/795>. Acesso em: 05 set. 2018.

OLLAIK, L. G.; ZILLER, H. M. Concepções de validade em pesquisas qualitativas. Educação e Pesquisa, v. 38, n. 1, p. 229-241, 2012.

OLWEUS, D. Bullying at school: what we know and what can we do. Oxford, UK: Blackwell, 1993.

ORSINI, A. G. S.; LARA, C. A. S. Dez anos de práticas restaurativas no Brasil: a afirmação da justiça restaurativa como política pública de resolução de conflitos e acesso à justiça.

Responsabilidades, Belo Horizonte, v. 2, n. 2, p. 305-324, fev. 2013. Disponível em: $<$ http://as1.trt3.jus.br/bd-

trt3/bitstream/handle/11103/2631/adriana_sena_dez_anos_praticas_restaurativas.pdf?sequenc $\mathrm{e}=1 \&$ isAllowed=y>. Acesso em: 20 jul. 2018.

ORTEGA, R.; DEL REY, R. Estratégias educativas para a prevenção da violência. Brasília: UNESCO, 2002. Disponível em: <http://unesdoc.unesco.org/images/0012/001287/128721 por.pdf〉. Acesso em: 19 nov. 2018.

PERES, M. F. T.; RUOTTI, C.; CARVALHO, D.; REGINA, F. L. Vitimização fatal de crianças no espaço público em decorrência da violência interpessoal comunitária: um diagnóstico da magnitude e contextos de vulnerabilidade na América Latina. In: $9^{\circ}$ ENCONTRO ANUAL DO FÓRUM BRASILEIRO DE SEGURANÇA PÚBLICA, 28., 
2015, Rio de Janeiro. Paper para discussão no workshop "Prevention of Violence against Children in Latin America”. Rio de Janeiro: Fundação Getúlio Vargas, 2015.

PINTO, R. S. G. A construção da justiça restaurativa no Brasil. Revista Paradigma, Ribeirão Preto, ano XV, n. 19, jan./jul. 2010. Disponível em:

<http://revistas.unaerp.br/paradigma/article/view/65/70>. Acesso em: 05 ago. 2018.

POSSATO, B. C.; RODRÍGUEZ-HIDALGO, A. J.; ORTEGA-RUIZ, R.; ZAN, D. D. P. O mediador de conflitos escolares: experiências na América do Sul. Psicologia Escolar e Educacional, v. 20, n. 2, p. 357-366, 2016. Disponível em:

<http://www.scielo.br/pdf/pee/v20n2/2175-3539-pee-20-02-00357.pdf>. Acesso em: 20 nov. 2018.

PREFEITURA MUNICIPAL DE RIBEIRÃO PRETO. Educação. Unidades Escolares. Disponível em: <https://www.ribeiraopreto.sp.gov.br/seducacao/escolas/i15unidadesindice.php>. Acesso em: 02 jun. 2018.

PRIOTTO, E. P. Violência escolar políticas públicas e práticas educativas no município de Foz do Iguaçu. Foz do Iguaçu: EDUNIOESTE, 2011.

RAMOS-JIMÉNEZ, A.; HERNÁNDEZ-TORRES, R.P; MURGUÍA-ROMERO, M.; VILLALOBOS-MOLINA, R. Prevalence of bullying by gender and education, in a city with high violence and migration in Mexico. Revista Panamericana de Salud Pública, v. 41, n. e37, p. 1-6, 2017. Disponível em: <https://www.ncbi.nlm.nih.gov/pubmed/28591332>. Acesso em: 01 nov. 2018.

ROSA, C. M.; PIERIN, L. A. Z.; MATHEUS, Y. L. Estudantes e as violências escolares: protagonistas ou vítimas? Cadernos da Pedagogia, v. 11, n. 22, p. 40-50, 2018.

SAFARIA, T. Prevalence and Impact of Cyberbullying in a Sample of Indonesian Junior High School Students. The Turkish Online Journal of Educational Technology, v. 15, n. 1, p. 82-91, 2016. Disponível em: 〈http://www.tojet.net/articles/v15i1/1519.pdf〉. Acesso em: 29 out. 2018.

SÁNCHEZ-QUEIJA, I.; GARCÍA-MOYA, I.; MORENO, M. Trend Analysis of Bullying Victimization Prevalence in Spanish Adolescent Youth at School. Journal of School Health, v. 87, n. 6, p. 457-464, 2017. Disponível em:

<https://onlinelibrary.wiley.com/doi/pdf/10.1111/josh.12513>. Acesso em: 31 out. 2018.

SÃO PAULO. Assembleia Legislativa do Estado de São Paulo. Lei no 16.279, de 08 de julho de 2016. Aprova o Plano Estadual de Educação de São Paulo e dá outras providências. Disponível em: <https://www.al.sp.gov.br/repositorio/legislacao/lei/2016/lei-1627908.07.2016.html>. Acesso em: 05 mai. 2018.

SCHERER, Z. A. P. (Org.). Cartilha Violência Escolar: ações de intervenção e prevenção. Ribeirão Preto: Escola de Enfermagem de Ribeirão Preto da Universidade de São Paulo, 2018. Disponível em: <http://conteudosdigitais.eerp.usp.br/cartilhas/cartilhaviolencia.pdf>. Acesso em: 06 nov. 2018.

SCHERER, Z. A. P.; SCHERER, E. A.; COCENAS, S. A.; GREGORIO, A. S. Grupo de atividades estruturadas com estudantes: identificação de violência no ambiente escolar. 
Revista Cultura e Extensão USP, v. 6, p. 111-119, 2011. Disponível em:

<https://www.revistas.usp.br/rce/article/view/552/552>. Acesso em: 03 set. 2017.

SCHILLING, F.; ANGELUCCI, C. B. Conflitos, violências, injustiças na escola? Caminhos possíveis para uma escola justa. Cadernos de Pesquisa, v. 46, n. 161, p. 694-715, 2016. Disponível em: <http://www.scielo.br/pdf/cp/v46n161/1980-5314-cp-46-161-00694.pdf>. Acesso em: 11 set. 2016.

SCHULTES, M. T.; STEFANEK, E.; SCHOOT, R. V.; STROHMEIER, D.; SPIEL, C. Measuring implementation of a school-based violence prevention program: fidelity and teachers' responsiveness as predictors of proximal outcomes. Zeitschriftfür Psychologie, v. 222, n. 1, p. 49-57, 2014. Disponível em: <http://econtent.hogrefe.com/doi/pdf/10.1027/21512604/a000165>. Acesso em: 05 nov. 2018.

SHUKLA, K.; KONOLD, T.; CORNELL, D. Profiles of Student Perceptions of School Climate: Relations with Risk Behaviors and Academic Outcomes. Am J Community Psychol, v. 57, p. 291-307, 2016. doi: 10.1002/ajcp.12044.

SILVA, A. B. B. Bullying: cartilha 2010 - projeto justiça nas escolas. Brasília: CNJ/FMU, 2010. Disponível em: <www.cnj.jus.br/images/programas/justicaescolas/cartilha_bullying.pdf>. Acesso em: 15 nov. 2018.

SILVA, D. T. G. Estratégias de prevenção da violência escolar: revisão integrativa da literatura. Dissertação (Mestrado em Ciências), Programa de Pós-Graduação em Enfermagem Psiquiátrica, Escola de Enfermagem de Ribeirão Preto da Universidade de São Paulo, Ribeirão Preto, 2018, 94p.

SILVA, F. R.; ASSIS, S. G. Prevenção da violência escolar: uma revisão da literatura. Educação e Pesquisa, v. 44, e157305, p. 1-13, 2018. Disponível em: <http://www.scielo.br/pdf/ep/2017nahead/1517-9702-ep-S1517-9702201703157305.pdf〉. Acesso em: 06 nov. 2018.

SILVA, J. M. A. P.; SALLES, L. M. F. A violência na escola: abordagens teóricas e propostas de prevenção. Educar em Revista, n. 2, p. 217-232, 2010. Disponível em: <http://www.scielo.br/pdf/er/nspe2/13.pdf>. Acesso em: 19 nov. 2018.

SPOSITO, M. P. Uma perspectiva não escolar no estudo sociológico da escola. Revista USP, n. 57, p. $210-226,2003$.

STAECKER, E.; PUETT, E.; AFRASSIAB, S.; KETCHERSIDE, M.; AZIM, S. ; WANG, A. Effectiveness of an afterschool- based aggression management program for elementary students. Asca, v. 19, n. 1, 2016. doi: 10.5330/1096-2409-19.1.125.

STEFANINI, J. R. Compreensões dos pais sobre o Transtorno de Déficit de Atenção/Hiperatividade em adolescentes e a exposição desses em situações de violência. 2014. 112 f. Dissertação (Mestrado em Ciências), Programa de Pós-Graduação em Enfermagem Psiquiátrica, Escola de Enfermagem de Ribeirão Preto da Universidade de São Paulo, Ribeirão Preto, 2014. Disponível em: <http://www.teses.usp.br/teses/disponiveis/22/22131/tde-19022015-192534/pt-br.php>. Acesso em: 02 nov. 2018. 
STEFANINI, J. R. Violência Contra a Mulher: relatos das mulheres atendidas pelo Centro de Referência e Atendimento à Mulher CRAM. 2009. Trabalho de Conclusão de Curso (Bacharel em Enfermagem) - Centro de Ensino Superior de Maringá, Paraná, 2009.

STELKO-PEREIRA, A. C.; WILLIAMS, L. C. A. Reflexões sobre o conceito de violência escolar e a busca por uma definição abrangente. Temas em Psicologia, v. 18, n. 1, p. 45-55, 2010. Disponível em: <http://pepsic.bvsalud.org/pdf/tp/v18n1/v18n1a05.pdf>. Acesso em: 19 nov. 2018.

STRINGER, E. T. Action Research. New York: The Sage, 2007.

TAVARES, P. A.; PIETROBOM, F. C. Fatores associados à violência escolar: evidências para o Estado de São Paulo. Estudos Economia, v. 46, n. 2, p. 471-498, 2016. Disponível em: 〈http://dx.doi.org/10.1590/0101-416146277ptf>. Acesso em: 04 nov. 2018.

THIOLlENT, M. Metodologia da Pesquisa-ação. 18 ed. São Paulo: Cortez, 2011.

THUMANN, B. F.; NUR, U.; NAKER, D.; DEVRIES, K. M. Primary school students' mental health in Uganda and its association with school violence, connectedness, and school characteristics: a cross-sectional study. BMC Public Health, v. 16, n. 662, p. 2-11, 2016. Disponível em: <https://www.ncbi.nlm.nih.gov/pubmed/27473040. Acesso em 31 out. 2018.

TOGNETTA, L. R. P.; DAUD, R. P. Formação docente e superação do bullying: um desafio para tornar a convivência ética na escola. Perspectiva, v. 36, n. 1, p. 369-384, 2018.

Disponível em: <https://doi.org/10.5007/2175-795X.2018v36n1p369>. Acesso em: 17 nov. 2018.

TOLEDO, R. F.; GIATTI, L. L.; JACOBI, P. R. A pesquisa-ação em estudos interdisciplinares: análise de critérios que só a prática pode revelar. Interface, v. 18, n. 51, out./dez. 2014. doi: 10.1590/1807-57622014.0026.

TRIPP, D. Pesquisa-ação: uma introdução metodológica. Educação e Pesquisa, v. 31, n. 3, p. 443-466, 2005. Disponível em: 〈http://www.scielo.br/pdf/ep/v31n3/a09v31n3.pdf>. Acesso em: 12 set. 2018.

TURATO, E. R. Tratado da metodologia da pesquisa clínico-qualitativa: construção teórico-epistemiológica, discussão comparada e aplicação nas áreas da saúde e humanas. Petrópolis: Vozes; 2011.

VILA NOVA, I. S.; SENA, C. L.; OLIVEIRA, I. R. Ocorrência do bullying entre alunos de uma escola pública do município de Salvador, Brasil. Revista de Ciências Médicas e

Biológicas, v. 14, n. 3, p. 338-342, 2015. Disponível em:

<https://repositorio.ufba.br/ri/bitstream/ri/23254/1/12_v.14_3.pdf>. Acesso em: 01 nov. 2018.

VILALTA, C. J.; FONDEVILA, G. School Vandalism in Mexico. Journal of School

Violence, v. 17, n. 3, p. 392-404, 2018. Disponível em:

<https://doi.org/10.1080/15388220.2017.1355809>. Acesso em: 31 out. 2018.

WAGNER, M. R. A mediação transformativa reflexiva de conflitos como proposta de tratamento do bullying na situação peculiar de vizinhança escolar. Revista Juventude e Políticas Públicas, v. 2, p. 14-24, 2018. Disponível em: <http://dx.doi.org/10.22477/25257161.2018.2ne.25-39>. Acesso em: 20 nov. 2018. 
WANDERA, S. O.; CLARKE, K.; KNIGHT, L.; ALLEN, E.; WALAKIRA, E.; NAMY, S.; NAKER, D.; DEVRIES, K. Violence against children perpetrated by peers: a cross-sectional school-based survey in Uganda. Child Abuse \& Neglect, v. 68, p. 65-73, 2017. Disponível em: <https://www.sciencedirect.com/science/article/pii/S0145213417301424>. Acesso em: 31 out. 2018.

WOODBRIDGE, M. W.; SUMI, W. C.; WAGNER, M.M.; JAVITZ, H. S.; SEELEY, J. R.; WALKER, H. M.; SMALL, J. W.; GOLLY, A.; FEIL, E.G.; SEVERSON, H. H. Does first step to success have long-term impacts on student behavior? An analysis of efficacy trial data. School Psychology Review, v. 43, n. 3, p. 299-317, 2014. Disponível em:

<https://www.questia.com/read/1G1-386433956/does-first-step-to-success-have-long-termimpacts>. Acesso em 06 nov. 2018.

WORLD HEALTH OGANIZATION (WHO). Global status report on violence prevention 2014. Luxemburgo: WHO, 2014. Disponível em:

<http://www.undp.org/content/dam/undp/library/corporate/Reports/UNDP-GVA-violence2014.pdf>. Acesso em: 06 nov. 2018.

YOSHINAGA, A. C. M.; PEREIRA, B. O.; OLIVEIRA, W. A.; GONÇALVES, I. P.; HAYASHIDA, M.; SILVA, M. A. I. Intervenção antibullying proposta por enfermeiros: elaboração e validação pelo método Delphi. Aletheia, v. 51, n. 1-2, p. 8-20, jan./dez. 2018. 


\section{APÊNDICES}

\section{APÊNDICE A - Termo de Consentimento Livre e Esclarecido}

Caro participante,

Gostaríamos de convidá-lo para participar da pesquisa "Transtornos mentais e violência na escola: percepção dos professores da rede pública de ensino". Você foi escolhido(a) por ser professor de uma instituição pública de ensino fundamental e de ensino médio. Sua participação não é obrigatória. $\mathrm{O}$ objetivo geral desta pesquisa consiste em compreender os sentidos e significados que os transtornos mentais na infância e na adolescência têm para professores de uma instituição pública de ensino fundamental e de ensino médio e a percepção destes sobre a ocorrência de violência neste contexto escolar.

O benefício de sua participação consiste em ajudar na compreensão de sua visão quanto aos transtornos mentais que ocorrem na infância e na adolescência e a violência no contexto escolar. Ao longo dos encontros, com suas respostas, podemos elaborar uma cartilha educativa para capacitação dos professores do ensino fundamental e do ensino médio, e poderá ser utilizada, posteriormente, em capacitações de outros profissionais.

Em dia e horário agendado, o participante responderá a um questionário de autopreenchimento e gostaríamos de contar com sua presença e participação em reuniões de grupo estruturadas (com questões voltadas para o tema do estudo), a serem desenvolvidas na Escola Estadual Professora Glete de Alcântra (EEPGA), coordenadas por uma aluna de Pósgraduação Doutorado e uma aluna do curso de graduação e licenciatura em Enfermagem da Escola de Enfermagem de Ribeirão Preto da Universidade de São Paulo (EERP/USP). Serão encontros com duração de uma hora e meia a duas horas por um período de 10 meses e serão gravados com uso de gravador.

A qualquer momento você pode desistir de participar e retirar sua participação. Se você não quiser participar, isso não trará nenhum prejuízo em sua relação com as pesquisadoras, Escola de Enfermagem de Ribeirão Preto ou serviços de saúde ou de educação. Este estudo não deve oferecer qualquer despesa ou desconforto para você. Esta pesquisa não envolve procedimentos invasivos, no entanto, há possibilidade de riscos, tais como: você se sentir ansioso(a) e constrangido(a) diante dos tópicos discutidos e dos membros do grupo, ou mesmo preocupado(a) com a garantia do sigilo. Quanto à ansiedade e constrangimento, os encontros serão realizados em local privativo, conduzidos pelas coordenadoras do grupo, de maneira empática, acolhedora e respeitosa. Quanto ao sigilo, será solicitado aos membros participantes do grupo que respeitem a confidencialidade das informações obtidas durante o desenvolvimento da atividade, porém não há garantias plenas diante de um grupo. No âmbito do tratamento dos dados coletados, as informações advindas dos membros do grupo serão confidenciais e será assegurado que seu nome não será divulgado.

Caso se perceba qualquer risco ou dano à sua pessoa, não previstos neste termo, as atividades desta pesquisa poderão ser imediatamente suspensas. A qualquer momento as pesquisadoras estarão à sua disposição para esclarecimentos com relação à pesquisa. $\mathrm{Na}$ ocorrência de algum dano relacionado à participação da pesquisa, será garantido o direito de indenização pelo pesquisador e instituições envolvidas.

Os resultados dessa pesquisa serão apresentados em Congressos da área e publicados em revista científica, garantindo-se sempre o sigilo dos nomes dos participantes.

Esta pesquisa foi aprovada pelo Comitê de Ética e Pesquisa da Escola de Enfermagem (EERP-USP), que tem a função de proteger os participantes da pesquisa, e que poderá ser 
acionado caso necessário, de segunda a sexta-feira, das $8 \mathrm{~h}$ às $17 \mathrm{~h}$, pelo telefone (16) 33153386.

Após a assinatura deste Termo de Consentimento Livre e Esclarecido, você receberá uma via do mesmo, no qual constam o telefone e o endereço das pesquisadoras, podendo tirar suas dúvidas sobre o projeto e sua participação, agora ou a qualquer momento.

Declaro que foram cumpridas as exigências contidas no item IV.3 da Resolução nº466, de 12 de dezembro de 2012.

Nome do pesquisador:

Contatos dos responsáveis pelo acompanhamento da pesquisa:

Jaqueline Rodrigues Stefanini

e-mail: jaquelinestefanini@ hotmail.com
Profa. Dra. Zeyne A. Pires Scherer

e-mail: Scherer@eerp.usp.br

Consentimento pós-esclarecido

Eu confirmo que

explicou-me o objetivo dessa pesquisa, bem como a forma de participação. Estou ciente das informações sobre a pesquisa e entendo que minha participação é voluntária, não me causarão nenhum dano, risco ou ônus. Será mantido segredo das informações contidas nas entrevistas. Tenho ciência da segurança de que não terei nenhuma despesa financeira durante o desenvolvimento da pesquisa, da garantia de que todas as informações fornecidas serão utilizadas apenas na construção da pesquisa e ficarão sob guarda dos pesquisadores, podendo ser requisitadas por mim a qualquer momento e que posso me recusar a responder a alguma pergunta. Autorizo a gravação e transcrição da entrevista.

Ribeirão Preto/SP,

Nome do participante: 


\section{APÊNDICE B - Questões Disparadoras do Grupo Focal}

1) O que vocês entendem por violência escolar?

2) Vocês já vivenciaram alguma forma de violência escolar ou sabem de alguém que tenha vivenciado? Como foi?

3) A que vocês atribuem o surgimento da violência na escola?

4) Em sua opinião, como poderia resolver a violência escolar?

5) Como vocês abordam o agressor e a vítima em situações de violência escolar?

6) O que vocês entendem por saúde mental?

7) Vocês trabalham a saúde mental na escola? Como?

8) Vocês realizam atividades na escola para o enfrentamento da violência e promoção de saúde mental? Quais?

9) Sente necessidade de aporte (preparo/esclarecimento/atualização) sobre as temáticas violência e saúde mental? O que você sugere? 
APÊNDICE C - Ação educativa: Habilidades para a gestão construtiva do conflito e prevenção da violência escolar

\section{PROPOSTA EDUCATIVA}

Tema: Integração teoria e prática com ênfase no desenvolvimento de habilidades para a gestão construtiva de conflitos e prevenção da violência escolar.

\section{Objetivos:}

- Compreender e refletir acerca dos temas conflitos (fases de evolução) e violência escolar (definições, tipologia e natureza dos atos violentos), buscando estratégias para prevenção;

- Promover a vivência de uma prática educativa dialógica com vistas às ações para prevenção da violência escolar;

- Desenvolver habilidades para a gestão construtiva de conflitos e prevenção da violência escolar.

\begin{tabular}{|c|c|c|}
\hline Proposta educativa & Tempo & Recursos \\
\hline 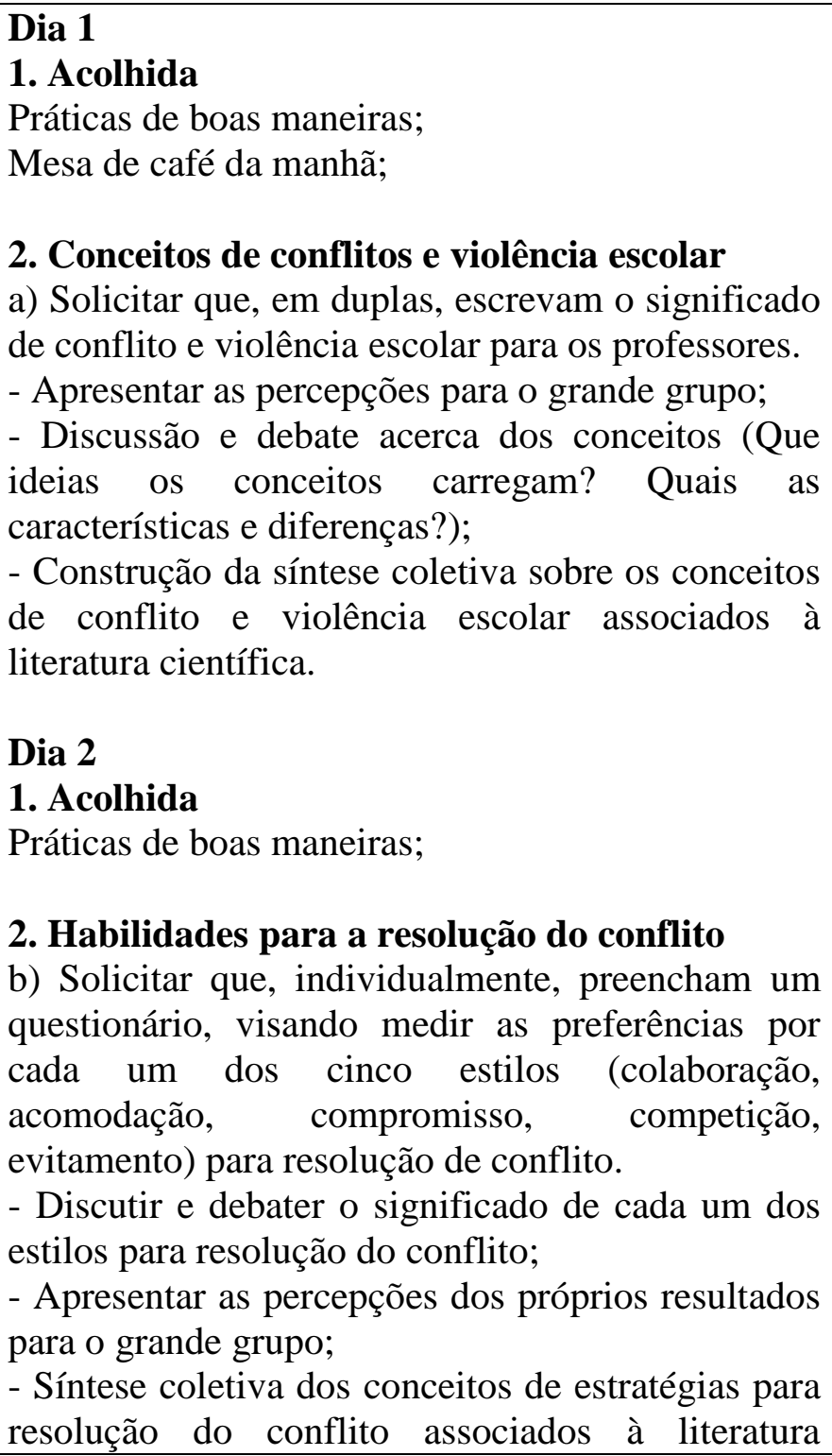 & $\begin{array}{l}\mathbf{1 5} \\
5 \\
10 \\
\mathbf{5 0} \\
10 \\
\\
10^{\prime} \\
10\end{array}$ & $\begin{array}{l}\text { Papel Kraft e pincel } \\
\text { atômico }\end{array}$ \\
\hline
\end{tabular}


científica;

3. Habilidades para a gestão construtiva de conflitos e prevenção da violência escolar.

40,

c) Solicitar que, em dupla, a partir da leitura uma situação problema, relacionem os conceitos discutidos com a sua resolução.

- Responder as 5 perguntas disparadoras para reflexão;

- A partir das ideias propostas, relacionar com os conceitos que discutimos;

- Síntese coletiva das ações sugeridas para resolução do problema apresentado.

Avaliação
Situação problema e perguntas norteadoras impressas
10’ Lousa e pincel atômico

$10^{\prime}$

$10^{\prime}$

\section{Referências:}

CUNHA, P.; LEITÃO, S. Manual de gestão construtiva de conflitos. 3 ed. Porto, Portugal: Edições Universidade Fernando Pessoa, 2016.

FEARNOW-KENNEY, M., HILL, P., GORE, N. Child and parent voices on a communitybased prevention program (FAST). The School Community Journal, v. 26, n. 1, p. 223-238, 2016.

HUTCHINGS, J.; MARTIN-FORBES, P.; DALEY, D.; WILLIAMS, M. E. A randomized controlled trial of the impact of a teacher classroom management program on the classroom behavior of children with and without behavior problems. Journal of School Psychology, 51, p. 571-585, 2013.

LEADBEATER, B. J.; THOMPSON, K.; SUKHAWATHANAKUL, P. Enhancing Social Responsibility and Prosocial Leadership to Prevent Aggression, Peer Victimization, and Emotional Problems in Elementary School Children. Am J Community Psychol, v. 58, p. 365-376, 2016.

McCORMAC, M. E. Preventing and Responding to Bullying: An Elementary School's 4-Year Journey. Professional School Counseling, v. 18, n. 1, p. 1-14, 2015.

POSSATO, B. C.; RODRÍGUEZ-HIDALGO, A. J.; ORTEGA-RUIZ, R.; ZAN, D. D. D. P. O mediador de conflitos escolares: experiências na América do Sul. Psicologia Escolar e Educacional, v. 20, n. 2, p. 357-366, 2016.

SCHULTES, M. T. et al. Measuring implementation of a school-based violence prevention program: Fidelity and teachers' responsiveness as predictors of proximal outcomes.

Zeitschriftfür Psychologie, v. 222, n. 1, p. 49-57, 2014. 